\title{
EFFECTS OF COMPOST, LEGUME COVER CROPPING AND VERMICOMPOST EXTRACT FOLIAR APPLICATIONS ON NUTRITION AND YIELD OF WASHINGTON NAVEL ORANGES
}

\author{
A Thesis \\ presented to \\ the Faculty of California Polytechnic State University, \\ San Luis Obispo
}

\begin{abstract}
In Partial Fulfillment
of the Requirements for the Degree

Master of Science in Agriculture,

with Specialization in Crop Science
\end{abstract}

by

William Payton Carling

August, 2012 
(C) 2012

William Payton Carling

ALL RIGHTS RESERVED

Page ii 
COMMITTEE MEMBERSHIP

TITLE:

AUTHOR:

DATE SUBMITTED:

COMMITTEE CHAIR:

COMMITTEE MEMBER:

COMMITTEE MEMBER:
Effects of Compost, Legume Cover Cropping and Vermicompost Extract Foliar Applications on Nutrition and Yield of Washington Navel Oranges

William Payton Carling

August 2012

Dr. John Phillips, Professor

Horticulture and Crop Science Department California Polytechnic State University, San Luis Obispo, California

Dr. Robert Flores, Professor Agricultural Education \& Communication Department

California Polytechnic State University, San Luis Obispo, California

Dr. Lauren Garner, Professor Horticulture and Crop Science Department California Polytechnic State University, San Luis Obispo, California 


\begin{abstract}
Effects of Compost, Legume Cover Cropping and Vermicompost Extract Foliar Applications on Nutrition and Yield of Washington Navel Oranges William Payton Carling
\end{abstract}

An experiment was conducted to test the effects of four treatments on Washington navel orange (Citrus sinensis) trees in regards to nutrient content of the leaves and fruit, soil nutrient content and properties, and fruit yield. The four treatments included: compost (C) and vermicompost extract foliar (VEF) applications, legume cover cropping (LCC) and VEF applications, VEF applications, and a control. The treatments were implemented from February 2010 to April 2011 and sampling occurred in May 2011. Fruit Growers Laboratory, Inc. (FGL) conducted the soil, leaf, and fruit analyses. The test site was located in San Isidro, Baja California Sur, Mexico.

The compost used was made onsite with livestock manure, carbon-based farm waste, and water, and applied around the drip-lines of 8 WNO trees once every two months. The vermicompost and vermicompost extract was made onsite by introducing red wiggler worms (Eisenia fetida) into horse manure, allowing 1 month for casting content to build up, and collecting the extract as water was filtered through the material. Vermicompost extract was applied using a backpack foliar sprayer on 8 WNO trees twice a month. The legume cover crop treatment consisted of two plantings at a rate of approximately 72 seeds per square foot around the drip-lines of 8 WNO trees. Blackeyed peas (Vigna unguiclata) were planted in April 2010 and minimally incorporated 
using a hoe and shovel in August 2010. Fababeans (Vicia faba) and dry peas (Pisum sativum) were planted in January 2011 and minimally incorporated into the soil in March 2011. WNO leaf and soil analyses were compared to FGL optimum ranges.

The C+VEF treatment showed trends of increased soil and leaf nitrogen, phosphorus, potassium, calcium, zinc, and copper levels and improved soil properties by raising soil organic matter percentage, saturation percentage, and moisture percentage. The control treatment had low or deficient values in these nutrients and soil properties. The LCC+VEF treatment increased nitrogen in the soil and leaf content but decreased organic matter percentage. The VEF treatment increased nitrogen and potassium content in the leaf but increased sodium beyond FGL optimum range. The C+VEF treatment had the highest yield and the greatest amount of nutrients removed as a result of yield. The $\mathrm{C}+\mathrm{VEF}$ treatment had more available nutrients in the soil for WNO tree uptake and future crops. 


\section{ACKNOWLEDGMENTS}

I want to thank the faculty and staff at Cal Poly State University for their adherence to excellence in education and academic professionalism, all accomplished with a sense of good cheer. I want to thank my family and friends for their support and encouragement throughout this project. I want to thank my academic advisor, Dr. John Phillips, for his work and patience, in guiding this thesis into proper form. As Dr. Phillips retires from a career as Professor of Agriculture, Crop Science here at Cal Poly, I want to thank him for his work marked by dedication, integrity, and purpose, and commitment to education and research in sustainable agriculture and the establishment of the Cal Poly experimental organic farm. I want to thank Raul Antonio Miranda Arce for the use of his orchard to conduct this thesis experiment when my orchard was severely damaged by hurricane Jimena. I want to thank Robin Verwest for her contributions in

photography, field work, and sampling assistance. I want to thank Chad Lessard and Fruit Growers Laboratory, Inc. I want to pay tribute to Dr. Tom Ruehr (1943-2009) for his life’s work in soil science and soil microbiology and shedding light to all questions unknown by reminding us time and time again, "Seek and ye shall find.” 


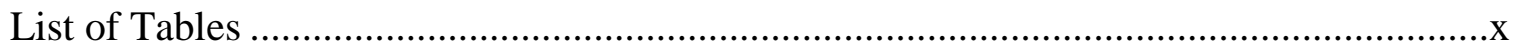

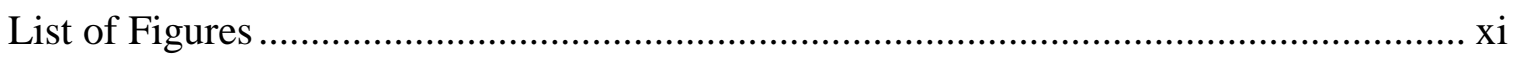

Chapter

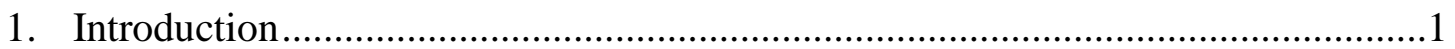

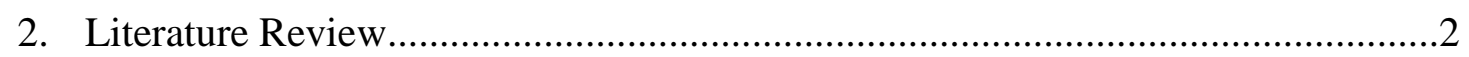

Washington Navel Orange (Citrus sinensis)....................................................

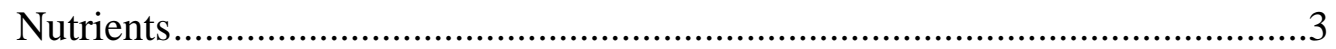

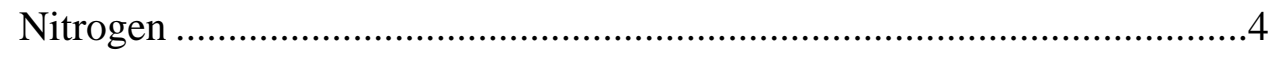

Phosphorus ........................................................................................

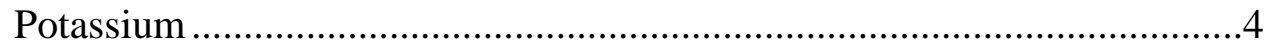

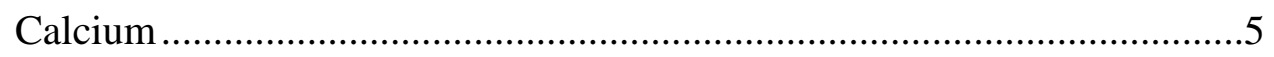

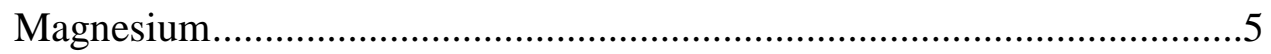

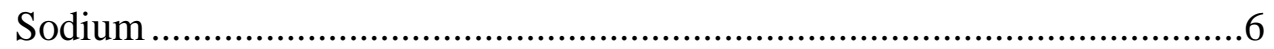

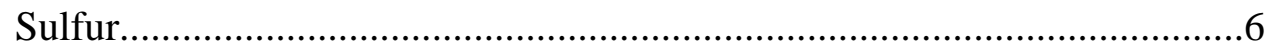

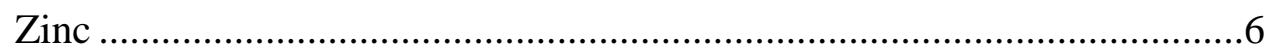

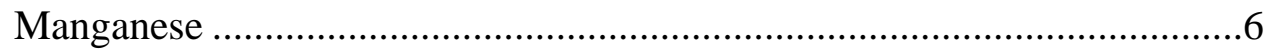

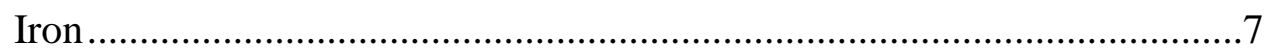

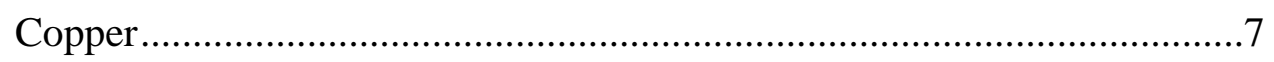

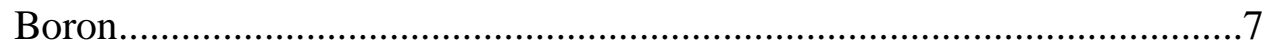

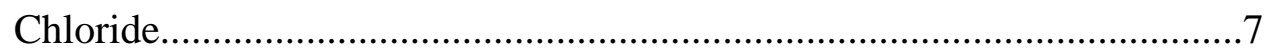

Compost Applications..................................................................................

Vermicompost Extract .................................................................................

Legume Cover Crops .....................................................................................11

3. Methods and Materials.........................................................................................

Site Description...........................................................................................12 


\section{TABLE OF CONTENTS (continued)}

Chapter

Page

Amendment Preparations and Applications of Treatments ...........................15

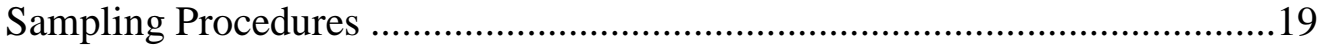

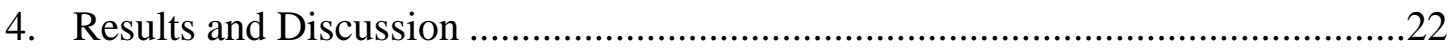

Soil and Leaf Analysis ........................................................................22

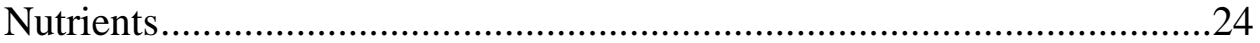

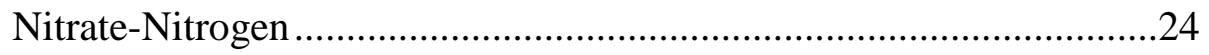

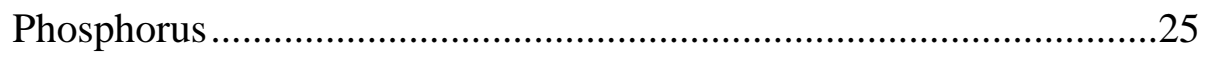

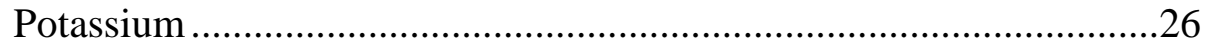

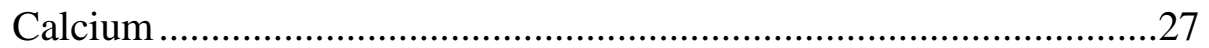

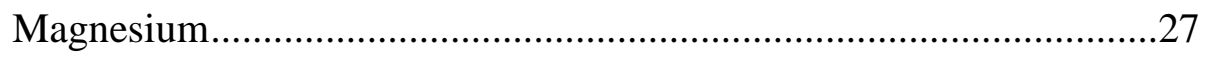

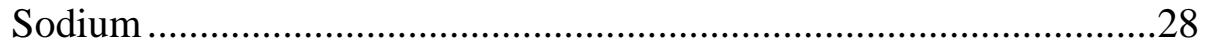

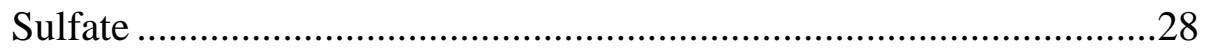

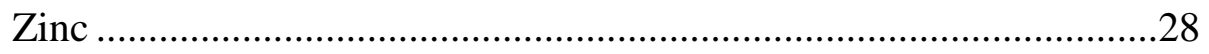

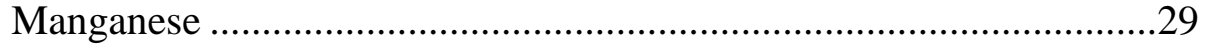

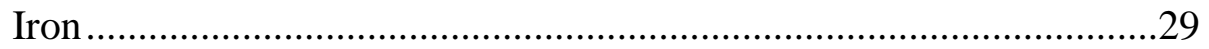

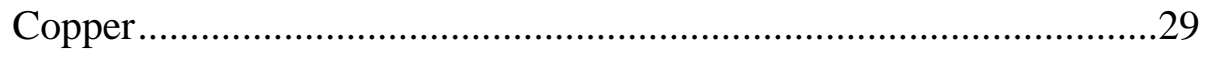

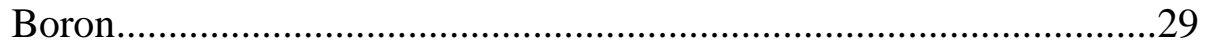

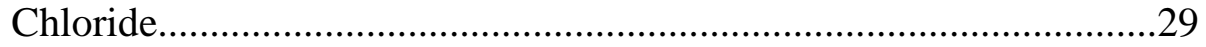

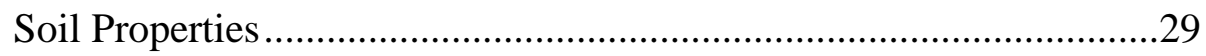

Fruit Yield and Fruit Nutrient Content .......................................................32

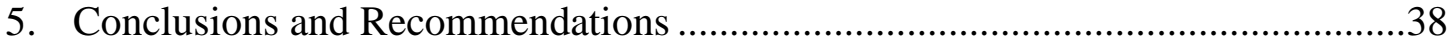

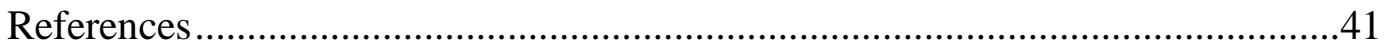




\section{TABLE OF CONTENTS (continued)}

Chapter $\quad$ Page

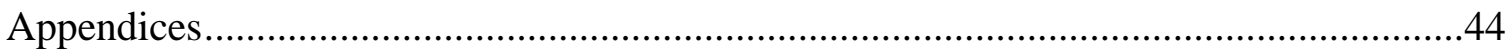

A. Fruit Growers Laboratory, Inc. Soil, Leaf, Water, and Amendment Analysis

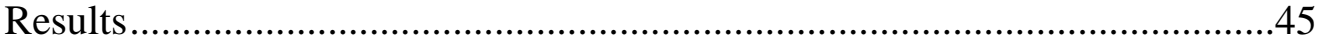

B. Statistical Analysis of Fruit Yield and Tree Size.................................................74

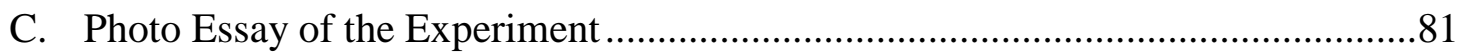

Experimental Site.........................................................................................81

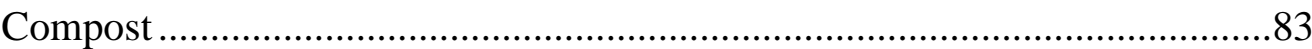

Legume Cover Crop .......................................................................................

Vermicompost Extract Foliar...........................................................................86

Washington Navel Orange Trees in Experiment ...............................................88

Compost and Vermicompost Extract Foliar ...............................................8

Legume Cover Crop and Vermicompost Extract Foliar ..............................90

Vermicompost Extract Foliar....................................................................92

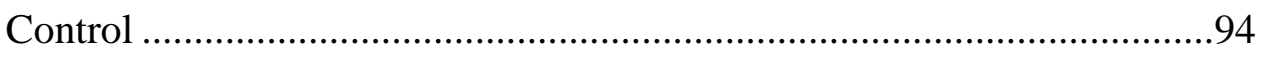

Google Earth Photo of Experimental WNO Orchard .........................................96 


\section{LIST OF TABLES}

Table

1. Temperature and Rainfall Data of La Purisima, Baja California Sur, Mexico

2. Irrigation Water Analysis of San Isidro, Baja California Sur, Mexico............16

3. Compost Amendment Analysis and Total Pounds of Nutrient Applied per Washington Navel Orange Tree in the C+VEF Treatment of the Experiment...

4. Vermicompost Amendment Analysis

5. Vermicompost Extract Analysis and Pounds of Nutrient Applied per Washington Navel Orange Tree in the VEF Treatment of the

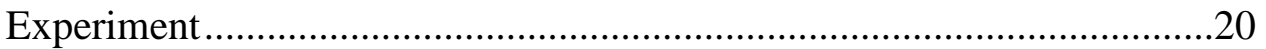

6. Effects of Four Nutrition Treatments on Soil Properties ...............................23

7. Effects of Four Nutrition Treatments on Leaf Tissue Analysis of Washington Navel Orange Trees

8. Effect of Four Nutrition Treatments on Mean Fruit Yield and Mean Nutrition Output of Washington Navel Orange Trees .... 


\section{LIST OF FIGURES}

Figure Page

1. Effect of Four Nutrient Treatments on Washington Navel Orange Yield ........32

2. Effect of Four Nutrient Treatments on Washington Navel Orange Yield.......33

3. Effect of Four Nutrient Treatments on Fruit Size of Washington Navel

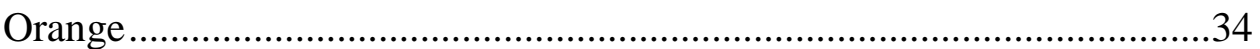

4. Height of Washington Navel Orange Trees Per Treatment, Measured at

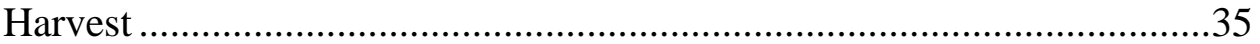

5. Circumference of Washington Navel Orange Trees Per Treatment,

Measured at Harvest .................................................................................36 


\section{CHAPTER 1}

Introduction

In 1996 the author bought a farm in La Purisima, Baja California Sur, Mexico. The existing orchards on the farm consisted of navel oranges (Citrus sinensis), mission figs (Ficus carica), dates (Phoenix dactyifera), mangos (Mangifera indica), grapes (Vitus vinifera), guavas (Psidium guajava), and Carrizo (Arundo donax). An acre of open field was under cultivation. In order to properly maintain a balance in nutrient cycling for optimum crop production, fertility amendment strategies needed to be implemented. The intent of this thesis is to quantify the effect of compost applications, legume cover cropping, and foliar applications of vermicompost extract on nutrient cycling of the Washington navel orange trees.

During the experimental time period two major hurricanes passed through the region resulting in crop and structural damage on the farm and changes in soil conditions of the original test site. After the hurricanes, another test site was established and the fertility strategies implemented. 


\title{
CHAPTER 2
}

\author{
Literature Review
}

This literature review covers Washington navel orange physiology, compost applications, vermicompost extract applications, and legume cover cropping.

\section{Washington Navel Orange (Citrus sinensis)}

Washington navel oranges (WNO) are grown in nearly all citrus growing regions of the world and are commercially important in Australia, the United States of America, Morocco, Mexico, South Africa, and Spain. The WNO originated in Brazil and was brought to Washington D.C. where it was distributed throughout the world in 1986 and became the most widely grown navel cultivar on earth. The fruit is important to fresh fruit markets worldwide for its high quality and the fact that the fruit contains the compound limonin which when oxidized instills bitterness to the juice thus limiting fruit processing. The oval or oblong shape fruit is seedless due to pollen and ovule sterility. The cultivar produces its highest quality fruit in Mediterranean climates and fairs well in hot, arid climates (Davies and Albrigo, 1998). 


\section{Nutrients}

The twelve macro- and micronutrients required for tree growth and yields, besides the readily available $\mathrm{C}, \mathrm{O}$, and $\mathrm{H}$, are macro-elements $\mathrm{N}, \mathrm{P}, \mathrm{K}, \mathrm{Mg}, \mathrm{Ca}, \mathrm{S}$, and microelements $\mathrm{Mn}, \mathrm{Cu}, \mathrm{Zn}, \mathrm{B}, \mathrm{Fe}$, and Mo. An optimum quantity of each element is necessary for optimum metabolic functioning and consistently high fruit production (Davies and Albrigo, 1998).

Nutrient uptake fluctuates during the different phases of fruit development (Storey and Treeby, 2001). During phase 1 cell division takes place and almost all cells of mature fruit are created. Phase 1 begins just after bloom and lasts 1 to $1 \frac{1 / 2}{2}$ months. Cell differentiation occurs during phase 2 and all the different fruit tissues are established. The duration of phase 2 is roughly 4 months for navel oranges. Phase 3 is the cell enlargement phase where cells increase in volume up to 1,000 times, and there is a rapid increase in fruit size and the percentage of total soluble solid. The duration of phase 3 for navel oranges fluctuates with climate and conditions from 3 to 4 months in the lowland tropics of Cartagena, Colombia to 10 months in the semiarid subtropical coastal climate of Santa Paula, California. Phase 4 is the maturation phase in which growth levels off and the total soluble solids increase and total acidity rapidly decreases. Fruit changes color from green to orange during the end of phase 4. In Mediterranean climates phase 4 can be 9 or 10 months and 1 or 2 months in the humid tropics. The time from bloom to fruit containing acceptable TSS:TA ratios for harvest differs from 6 or 7 months in the humid tropics to 14 to 16 months in Mediterranean climates. Soil moisture and 
temperature are the determining factors (Davies and Albrigo, 1998). Nutrient uptake in the fruit occurs most rapidly during phase 1 and early phase 2 (Storey and Treeby, 2001).

\section{Nitrogen}

The optimum range of nitrate-nitrogen in the soil is 40 to 80 pounds per acre-foot (lbs/AF) and 2.6\% to 2.8\% in leaf tissue (Fruit Growers Laboratory, Inc., 2011). Of all the elements, nitrogen has the greatest impact on tree growth and fruit production (Davies and Albrigo, 1998). Additional nitrogen increases the amount of fruit and flowering produced, but not the size. Nitrogen is found in all amino acids and proteins of the tree. Uptake of nitrogen, similar to all macro- and micronutrients, can occur through the leaf surface or roots and translocates through the transpiration stream throughout the tree. Fruit harvest accounts for yearly nitrogen removal per acre ranging from $20 \mathrm{~kg}$ to $60 \mathrm{~kg}$ in average to high yields and $100 \mathrm{~kg}$ in maximum yields (Smith, 1966a).

Phosphorus

Phosphorus is a major component in cell energy systems and cell structure (Davies and Albrigo, 1998). The optimum range of phosphorus in the soil is 140 to 280 lbs/AF and $0.12 \%$ to $21 \%$ in the leaf tissue (Fruit Growers Laboratory, Inc., 2011).

\section{Potassium}

Potassium is essential for regulating cell ionic balance and ensuring proper fruit size and peel thickness. The optimum range of potassium in the soil is exchangeable 680 to $4,100 \mathrm{lbs} / \mathrm{AF}$ and 94 to $470 \mathrm{lbs} / \mathrm{AF}$ in solution. The optimum range in leaf tissue is 
$0.70 \%$ to $3.3 \%$. Potassium plays a key role in fruit quality. Nitrogen to potassium ratios between 1.6 and 2.2 are the optimum for fruit size with leaf $\mathrm{N}$ greater than $1.8 \%$ and $\mathrm{P}$ greater than $0.9 \%$. Optimum ratios for overall fruit yield are between 2.4 to 3.0 (Davies and Albrigo, 1998). A navel orange crop of $100 \mathrm{~kg}$ contains $200 \mathrm{~g}$ of potassium (Storey and Treeby, 2001).

\section{Calcium}

The optimum range of calcium in the soil is 18,000 to $23,000 \mathrm{lbs} / \mathrm{AF}$ exchangeable and 160 to $640 \mathrm{lbs} / \mathrm{AF}$ in solution (Fruit Growers Laboratory, Inc., 2011). Optimum range in leaf tissue is between $3 \%$ and $5.5 \%$. Calcium comprises $20 \%$ of the elemental content of a mature citrus tree, thus it is a prevalent element. Calcium is involved in metabolite transport, enzyme functioning, and cell wall structural material (Davies and Albrigo, 1998).

\section{Magnesium}

Magnesium is necessary for many enzyme reactions within the tree (Davies and Albrigo, 1998). A navel orange crop of $100 \mathrm{~kg}$ contains 60 to $70 \mathrm{~g}$ of magnesium (Storey and Treeby, 2001). The optimum range of magnesium in the soil is 1,800 to 3,500 lbs/AF exchangeable and 73 to 220 lbs/AF in solution (Fruit Growers Laboratory, Inc., 2011). 


\section{Sodium}

The optimum range of sodium in the soil is 0 to $1,700 \mathrm{lbs} / \mathrm{AF}$ exchangeable and 0 to 1,200 lbs/AF in solution (Fruit Growers Laboratory, Inc., 2011).

\section{Sulfur}

Sulfur is a necessary part of proteins and enzymes in trees and is rarely deficient in citrus (Davies and Albrigo, 1998). The optimum range of sulfate in the soil is 120 to 3,800 lbs/AF (Fruit Growers Laboratory, Inc., 2011).

Zinc

Zinc deficiency is associated with the occurrence of citrus blight, citrus variegated chlorosis and smaller than normal leaves (Davies and Albrigo, 1998). The optimum range of zinc in the soil is 4 to $160 \mathrm{lbs} / \mathrm{AF}$ and 25 to $200 \mathrm{ppm}$ in leaf tissue (Fruit Growers Laboratory, Inc., 2011).

\section{Manganese}

The optimum range of manganese in the soil is 6.0 to $240 \mathrm{lbs} / \mathrm{AF}$ and 25 to 200 ppm in leaf tissue. Manganese becomes complexed and unavailable in high pH soils. Yellow patches between veins of young growing leaves are signs of manganese deficiency (Davies and Albrigo, 1998). 
Iron

The optimum range of iron in the soil is 40 to $160 \mathrm{lbs} / \mathrm{AF}$ and 60 to $200 \mathrm{ppm}$ in leaf tissue. Deficiency symptoms are chlorosis with a fine network of green veins in the leaf. Iron chelate can be applied to trees in high $\mathrm{pH}$ soil as a foliar spray or root feed (Davies and Albrigo, 1998).

\section{Copper}

The optimum range of copper in the soil is 1.2 to $41 \mathrm{lbs} / \mathrm{AF}$ and 5 to $40 \mathrm{ppm}$ in leaf tissue. Copper is important in the early development of citrus trees.

Boron

Boron has a narrow range between optimum, deficiency, and toxicity. The optimum range of boron in the soil is 1.2 to $8.4 \mathrm{lbs} / \mathrm{AF}$ and 31 to $300 \mathrm{ppm}$ in leaf tissue.

\section{Chloride}

The optimum range of chloride in the soil is 14 to $660 \mathrm{lbs} / \mathrm{AF}$.

All optimum nutrient ranges are the recommended levels by Fruit Growers Laboratory, Inc. as of 2011 and are based on experimentations by Smith (1996a, 1996b).

\section{Compost Applications}

The process of composting originated when the first forms of plant life appeared on earth and perished, thus completing their life-cycles, and microorganisms found 
niches in the decaying processes of the leftover material. Microorganisms turn dead plant and animal matter into humus and humus provides a medium and a slow release of nutrients for plant life. Early human agriculturalists discovered the soil enriching qualities of finished compost, or humus, not long after discovering tilling, planting, and irrigation (Rodale, 1971). Today, compost is one of the principal soil amendments used in organic agriculture and by gardeners world-wide.

Truly finished compost is humus. Humus is the product of the decomposing and synthetic activities of soil microorganisms on dead organic matter (DOM). DOM contains the optimum organic carbon to nitrogen ratio (between 10 to 1 and 30 to 1 ), and is necessary for microbial development. The microbial decomposition of DOM under suitable conditions of aeration and humidity produces brown or black organic complexes leaving no trace of the original material. Microbial protoplasm is synthesized and new compounds are formed. Humus contains compounds of carbon, hydrogen, oxygen, nitrogen, phosphorus, sulfur, and lesser amounts of the other elements (Alexander, 1977). Compost applications raise the organic matter content of soil thus increasing the cation-exchange capacity which is the nutrient reservoir for growing plants (Gaskell et al., 2000). Compost applications improve soil physical properties by decreasing bulk density and improving aggregate stability (Diacono and Montemurro, 2010). Soil aeration, drainage, and water holding capacity improves with an increase of soil organic matter (Gaskell et al., 2000). Ingham (2005) states that a 1\% increase of organic matter raises water content of the soil by 27,000 gallons per acre. Populations of vesicular arbuscular mycorrhizal (VAM) fungi rise as an effect of compost applications (Douds et al., 1997). Compost and vermicompost were found to improve soil properties by 
increasing $\mathrm{pH}$, nutrient, and organic matter content in degraded tropical soils (Jouquet et al., 2011).

Vermicompost contains higher VAM counts than composts without earthworms. As DOM is ingested and passes through the guts of earthworms, VAM populations are increased and dispersal is enhanced. VAM fungi have a symbiotic relationship with plant roots in regards to nutrient exchange and water availability (Edwards and Bohlen, 1996). In the citrus variety Jamhiri, a direct correlation was found between the presence of VAM in the roots and tree growth. Normal trees had 50\% more VAM infection than stunted trees (Weir et al., 1978). Compost and vermicompost soil amendments increased leaf content of the nutrients $\mathrm{Ca}, \mathrm{Mg}, \mathrm{Mn}, \mathrm{Fe}, \mathrm{Zn}$, and $\mathrm{Cu}$ in greenhouse lettuce (Hernandez et al., 2010).

Composting animal manures stabilizes nutrients by creating humus, a safe fertilizer which can be applied directly to growing crops (Kuepper, 2003). Animal manures must be managed properly to avoid nutrient leaching into surface or ground water systems causing eutrophication. Manure in hypoxic and anaerobic conditions stimulates microbial growth of human pathogens as well as plant pathogens (Kuepper, 2003).

\section{Vermicompost Extract}

Vermicompost extract is obtained by the passing of water through worm castings. Nutrients and microorganisms are extracted from the castings and the liquid is applied to plants as a foliar or root feeder. A brewing process takes place as the extraction is collected. The microorganisms continue to respire, metabolize, and reproduce. 
Microbial growth is stimulated with aeration and the addition of food. It is important for the extraction to be aerobic in order to retain the microbial species beneficial to plants (Ingham, 2005).

Ingham (2005), states that quality compost, necessary for quality extract, contains between 26,000 and 500,000 species of microorganisms in one gram. A complex ecosystem exists where bacteria and fungi consume DOM, immobilizing nutrients, and microarthropods, nematodes, and protozoa consume bacteria and fungi. Nutrients are mobilized by excretions of the upper trophic level species and are available for plant uptake and other microbial life.

According to Ingham (2000), as a foliar application, vermicompost extract benefits plants by creating conditions which stimulate leaf surface gas concentrations allowing stomata to open and remain open for respiration and plant uptake of nutrients. Nutrients in the extract remain on the leaf surface and release slowly over time for plant uptake. Beneficial microorganisms in the extract inhabit infection sites and leaf surfaces on the plant outcompeting pathogens. The colonization of beneficial microorganisms protects the plant from pathogenic invading species and provides an immediate and slow release source of nutrients. Produce nutritional quality is thusly enhanced (Ingham, 2005).

In an experiment conducted with pak choi (Brassica rapa), vermicompost extract applications increased plant production, mineral nutrients, antioxidant activity and total carotenoids (Plant et al., 2009). Aerated and non-aerated extract performed equally. Foliar applications of vermicompost extract were found to increase leaf area and fruit 
yield of strawberry (Fragaria nananassa) plants. Strawberry fruit yield was enhanced by a reduction of albinism, fruit malformation, and grey mold (Singh et al., 2009).

\section{Legume Cover Crops}

Planting winter and summer cover crops, living mulches, and forage crops are key management practices in sustainable organic agricultural systems. These practices increase soil organic matter, microbial activity, and nutrient content, and work to suppress weeds and pests. Nitrogen-fixing legumes incorporated into the cropping system add nitrogen which becomes available for plant uptake approximately one month after tillage (Sullivan, 2003).

In 1915 the New Mexico Agriculture Experiment Station published a paper recognizing the need for replenishment of soil organic matter and nutrients in fruit orchards. The station reported on an experiment conducted which tested the suitability and logistics of different cover crops planted in apple orchards located in southern New Mexico. It was determined that planting and tilling in cover crops annually can maintain soil fertility in fruit orchards (Garcia, 1915).

An experiment conducted in a Mediterranean climatic region of Chile found that annual cover cropping of clover mixes in vineyards resulted in optimum nitrogen levels for crop production (Ovalle et al., 2010). 


\title{
CHAPTER 3
}

\author{
Methods and Materials
}

\section{Site Description}

The site of the experiment is located in San Isidro, Baja California Sur, Mexico. San Isidro is located in the Cadegomo river valley, 26 degrees north latitude and 15 kilometers inland from the Pacific Ocean. The valley contains approximately 211 hectares of irrigated farmland and 153 individual farms. Irrigation canals run down the valley originating at two different dams. A karst system of river water flow surfaces throughout the valley forming many lagoons.

The desert climate of the region offered an average annual rainfall from 2006 to 2010 of 118.2 millimeters. The majority of precipitation occurred during late summer and early fall tropical storm and hurricane events. On September $2^{\text {nd }}$ and $3^{\text {rd }}$ of 2009 , $196.3 \mathrm{~mm}$ of rainfall was accumulated in 24 hours during the passing of hurricane Jimena. Winter, spring, and early summer received little or no precipitation (Table 1). Temperature fluctuations during the years 2006 to 2010 ranged from $0^{\circ} \mathrm{C}$ to $46^{\circ} \mathrm{C}$. Daily fluctuations between nighttime lows and daytime highs of $25^{\circ} \mathrm{C}$ to $30^{\circ} \mathrm{C}$ were common (Table 1).

The loamy soil of the valley is alluvial in formation with parent material of limestone and igneous rock. For WNO production the soil is low in nitrogen, 
Table 1. Temperature and Rainfall Data of La Purisima, Baja California Sur, Mexico. La Purisima Weather Station, Comundo Municipal Census.

\begin{tabular}{|c|c|c|c|c|c|c|c|c|c|c|c|c|}
\hline \multicolumn{13}{|c|}{ Mean Monthly Temperature $\left({ }^{\circ} \mathrm{C}\right)$} \\
\hline Year & Jan. & Feb. & Mar. & April & May & June & July & Aug. & Sept. & Oct. & Nov. & Dec. \\
\hline 2004 & 16.7 & 17.2 & 20.5 & 20.5 & 22.8 & 24.5 & 29.4 & 29.7 & 28.9 & 23.4 & 19.8 & 19.8 \\
\hline 2005 & 18.6 & 18.0 & 18.6 & 21.4 & 22.0 & 24.2 & 29.3 & 29.7 & 30.7 & 24.4 & 21.9 & 21.9 \\
\hline 2006 & 18.5 & 18.8 & 18.5 & 21.2 & 21.8 & 26.9 & 30.4 & 31.0 & 28.3 & 25.5 & 23.1 & 23.1 \\
\hline 2007 & 15.1 & 17.7 & 20.6 & 19.8 & 21.2 & 25.1 & 28.1 & 29.3 & 28.5 & 25.2 & 21.4 & 21.4 \\
\hline 2008 & 17.6 & 18.1 & 19.3 & 20.2 & 20.1 & 26.1 & 28.7 & 29.4 & 28.5 & 25.6 & 20.6 & 20.6 \\
\hline 2009 & 17.2 & 18.9 & 20.1 & 19.5 & 21.4 & 23.9 & 29.8 & 29.6 & 27.8 & 24.5 & 21.4 & 17.2 \\
\hline 2010 & 18.9 & 18.2 & 19.2 & 20.5 & 22.0 & 24.5 & 26.7 & 30.5 & 29.5 & 23.3 & 20.5 & \\
\hline \multicolumn{13}{|c|}{ Maximum Monthly Temperature $\left({ }^{\circ} \mathrm{C}\right)$} \\
\hline Year & Jan. & Feb. & Mar. & April & May & June & July & Aug. & Sept. & Oct. & Nov. & Dec. \\
\hline 2004 & 32 & 35 & 39 & 38 & 39 & 42 & 44 & 44 & 43 & 41 & 39 & 39 \\
\hline 2005 & 24 & 31 & 34 & 40 & 39 & 41 & 45 & 45 & 44 & 41 & 38 & 38 \\
\hline 2006 & 37 & 38 & 41 & 44 & 39 & 44 & 43 & 44 & 41 & 44 & 41 & 41 \\
\hline 2007 & 33 & 39 & 39 & 35 & 40 & 43 & 42 & 43 & 42 & 41 & 39 & 39 \\
\hline 2008 & 37 & 41 & 40 & 40 & 41 & 46 & 43 & 42 & 42 & 42 & 38 & 38 \\
\hline 2009 & 35 & 42 & 43 & 40 & 40 & 40 & 43 & 43 & 43 & 43 & 38 & 32 \\
\hline 2010 & 35 & 35 & 39 & 38 & 39 & 42 & 40 & 44 & 43 & 43 & 40 & \\
\hline \multicolumn{13}{|c|}{ Minimum Monthly Temperature $\left({ }^{\circ} \mathrm{C}\right)$} \\
\hline Year & Jan. & Feb. & Mar. & April & May & June & July & Aug. & Sept. & Oct. & Nov. & Dec. \\
\hline 2004 & 3 & 3 & 5 & 1 & 8 & 9 & 14 & 15 & 13 & 8 & 3 & 3 \\
\hline 2005 & 3 & 4 & 4 & 5 & 6 & 9 & 17 & 15 & 15 & 10 & 6 & 6 \\
\hline 2006 & 0 & 3 & 2 & 4 & 7 & 11 & 17 & 19 & 15 & 9 & 4 & 4 \\
\hline 2007 & 1 & 3 & 5 & 5 & 8 & 9 & 18 & 17 & 15 & 10 & 6 & 6 \\
\hline 2008 & 1 & 2 & 2 & 6 & 6 & 8 & 17 & 20 & 11 & 12 & 6 & 6 \\
\hline 2009 & 3 & 3 & 5 & 5 & 8 & 8 & 12 & 18 & 17 & 8 & 5 & 3 \\
\hline 2010 & 4 & 4 & 7 & 7 & 5 & 9 & 11 & 19 & 11 & 9 & 2 & \\
\hline \multicolumn{13}{|c|}{ Monthly Precipitation (mm) } \\
\hline Year & Jan. & Feb. & Mar. & April & May & June & July & Aug. & Sept. & Oct. & Nov. & Dec. \\
\hline 2004 & 0 & 0 & 0 & 0 & 0 & 0 & 5.5 & 0 & 53.1 & 0 & 0 & 0 \\
\hline 2005 & 15.9 & 23.0 & 7.3 & 0 & 6.4 & 0 & 4.7 & 0 & 0 & 0 & 0 & 0 \\
\hline 2006 & 0 & 0 & 0 & 0 & 0 & 0 & 8.0 & 7.4 & 43.5 & 83.4 & 0 & 0 \\
\hline 2007 & 0 & 0 & 0 & 0 & 0 & 0 & 0 & 3.0 & 12.5 & 0 & 21.2 & 21.2 \\
\hline 2008 & 5.4 & 0 & 0 & 0 & 0 & 0 & 0 & 28.5 & 182.4 & 0 & 7.9 & 7.9 \\
\hline 2009 & 0 & 0 & 0 & 0 & 0 & 0 & 5.7 & 4.2 & 196.3 & 52.2 & 0 & 7.0 \\
\hline 2010 & 9.4 & 2.1 & 0 & 0 & 0 & 0 & 0 & 25.4 & 0 & 0 & 0 & \\
\hline
\end{tabular}


phosphorus, potassium, and zinc. The soil is alkaline with a $\mathrm{pH}$ of 8.17. Soil organic matter is low at approximately 1.41\% (Fruit Growers Laboratory, Inc., 2011).

The valley holds a diversity of agricultural enterprises. Livestock is the most commercially important. The valley and outlying ranchland contain 4,098 head of cattle (Bos primigenius), 15,776 goats (Capra aegagrus hircus), and 257 horses (Equus ferus caballus). The 268 pigs (Sus scrofa domesticus) and 1,791 chickens (Gallus gallus Domesticus) are raised mainly for local consumption. The orchard cultivars include: 95 hectares of date palms (Phoenix dactylifera), 20 hectares of oranges (Citrus sinensis), 11 hectares of mangos (Mangifera indica), 13 hectares of figs (Ficus carica), and 25 hectares of ‘Tlaco’ palms (Erythea brahea brandegeei). The 2008 Census also recorded: 10 hectares of guavas (Psidium guajava), 7 hectares of grapes (Vitus vinifera), 5 hectares of avocados (Persea amerinana), 4 hectares of sugar cane (Saccharum officinarum), 2 hectares of olives (Olea europaea), and 13 hectares of various fruit (Comundu Municipal Census, 2008). The main annual crops are: fava beans (Vicia faba), peas (Pisum sativvum), onions (Allium cepa), garlic (Allium sativum), corn (Zea mays), tomatoes (Solanum lycopersicum), beans (Phaseolus lunatus), sorgum (Sorghum bicolor), watermelons (Citrullus lanatus), squash (Cucurbita moschata), and alfalfa (Medicago sativa) (Comundu Municipal Census, 2008).

The experiment took place in the WNO orchard of Raul Antonio Miranda Arce, or “Timy” as everyone calls him. Timy's farm, located in San Isidro, is 6 hectares and its enterprises reflect the diversity of the valley. He owns a herd of roughly 100 head of cattle. Eighty-five animals graze on his 100 hectare ranch and 15 are corralled at the farm in preparation for market. It was from these corrals that manure was collected for 
compost pile construction. Timy keeps 2 horses, 15 goats, 4 pigs, 3 milking cows, and chickens at the farm. Two hectares of the farm are fields for annual crops. Timy plants corn, beans, peas, onions, tomatoes, sorgum, and watermelon. The orchards grow dates, mangos, assorted citrus, guavas, ‘Tlaco’ palms, and figs. The WNO orchard is alley cropped with yellow (Melilotus officinalis) and white sweetclover (Melilotus alba) and buffelgrass (Pennisetum ciliare) used for animal feed.

The irrigation regime hinges on the rotation system of canal water running through the valley. The farm is ditch irrigated every 2 to 3 weeks depending on seasonal fluctuations in temperature and photoperiod. Irrigation water suitability for WNO production was assessed as fair by FGL (Appendix A, page 70). Irrigation water was sampled in May 2011, and its analysis is presented in Table 2.

\section{Amendment Preparations and Applications of Treatments}

Compost piles were constructed on site using the goat, cattle, and horse manures of the farm corrals and carbon-based materials of grasses and leaves from the farm. The bases of the piles were 5 feet wide and 9 feet long and dug 5 inches into the ground to retain moisture. A 3-inch layer of carbon-based material was spread at the base to begin the pile. The carbon layer was followed by a 1-inch layer of manure. The process of layering 3 inches of carbon and 1 inch of manure was continued until the pile reached 4 feet high. Water was added throughout the layering process, as well as a small amount of farm soil (Rodale, 1971). The piles composted for 1 month and then were turned. The compost was finished and ready for application 1 month after being turned. The manure 
Table 2. Irrigation Water Analysis of San Isidro, Baja California Sur, Mexico

\begin{tabular}{|c|c|}
\hline Test Description & Pounds Per Acre-Foot \\
\hline Calcium & 60 \\
\hline Magnesium & 52 \\
\hline Potassium & 11 \\
\hline Sodium & 310 \\
\hline Carbonate & 0 \\
\hline Bicarbonate & 600 \\
\hline Sulfate & 52 \\
\hline Chloride & 330 \\
\hline Nitrate & 0 \\
\hline Fluoride & 1 \\
\hline Boron & 1.1 \\
\hline Copper & 0 \\
\hline Iron & 0 \\
\hline Manganese & 0.054 \\
\hline Zinc & 0.11 \\
\hline TDS by Summation & 1,400 \\
\hline $\mathrm{pH}$ & 8.2 \\
\hline E.C. & 766 umhos/cm \\
\hline SAR & $4.3 \mathrm{mg} / \mathrm{L}$ \\
\hline
\end{tabular}

mix was $1 / 2$ to $3 / 4$ goat manure and equal parts horse and cattle. The carbon material in raw form was added $3 / 4$ of the time and shredded material $1 / 4$. The compost was analyzed as an amendment by FGL (Table 3).

The first compost pile was constructed by December 8, 2009 and applied February 20, 2010. Each of the eight replicate WNO trees received 9 cubic feet of compost spread evenly around the tree from trunk base to drip-line on the first application; 6 cubic feet of compost was applied in the same manner thereafter. Compost was applied once every two months ending in April 2011 at a rate of approximately 
Table 3. Compost Amendment Analysis and Total Pounds of Nutrient Applied per Washington Navel Orange Tree in the C+VEF Treatment of the Experiment. C+VEF stands for compost and vermicompost extract foliar.

\begin{tabular}{|l|c|c|}
\hline Constituent & Pounds Per Ton & Pounds Applied Per Tree \\
\hline Nitrogen & 15.9 & 1.16 \\
\hline Phosphorus & 20.8 & 1.51 \\
\hline Potassium & 15.7 & 1.14 \\
\hline Chloride & 3.24 & 0.23 \\
\hline Sodium & 3.46 & 0.25 \\
\hline Boron & 0.0564 & 0.004 \\
\hline Calcium & 46.6 & 3.4 \\
\hline Magnesium & 8.23 & 0.6 \\
\hline Zinc & 0.0591 & 0.0043 \\
\hline Manganese & 0.306 & 0.022 \\
\hline Iron & 4.05 & 0.256 \\
\hline Copper & 0.0172 & 0.000125 \\
\hline Soil Properties & & \\
\hline Salinity (EC) & 16.4 mmhos/cm & \\
\hline pH & 7.52 & $6.83 \%$ as received \\
\hline Moisture (\%) & 27.9 & $60.3 \%$ as received \\
\hline Organic Matter & $16.3 \%$ dried & \\
\hline Ash (\%) & $83.7 \%$ dried & \\
\hline Bulk Density & $797 \mathrm{lbs} / \mathrm{yd}^{3}$ & \\
\hline Carbon & $9.7 \%$ dried & \\
\hline Carbon:Nitrogen Ratio & & \\
\hline & & \\
\hline
\end{tabular}

28,289 pounds per acre. Three cubic feet of vermicompost was mixed with 3 cubic feet of compost and applied in June 2010 and October 2010 (see Table 4).

In following unpublished practices, two vermicompost tables were constructed consisting of plywood tops and 10-inch high wooden sides lined with thin plastic. The tables had legs 3 feet high with a $4 \%$ slope. The lower ends were not covered in plastic 
Table 4. Vermicompost Amendment Analysis

\begin{tabular}{|c|c|c|}
\hline Constituent & Pounds Per Ton & \\
\hline Nitrogen & 15.9 & \\
\hline Phosphorus & 13.3 & \\
\hline Potassium & 10.5 & \\
\hline Chloride & 1.84 & \\
\hline Sodium & 2.33 & \\
\hline Boron & 0.063 & \\
\hline Calcium & 23.7 & \\
\hline Magnesium & 7.65 & \\
\hline Zinc & 0.041 & \\
\hline Manganese & 0.211 & \\
\hline Iron & 2.12 & \\
\hline Copper & 0.0139 & \\
\hline \multicolumn{3}{|l|}{ Soil Properties } \\
\hline Salinity (EC) & $10.1 \mathrm{mmhos} / \mathrm{cm}$ & \\
\hline $\mathrm{pH}$ & 8.39 & \\
\hline Moisture (\%) & $59.20 \%$ & \\
\hline Organic Matter & $40.8 \%$ dried & $16.6 \%$ as received \\
\hline Ash (\%) & $59.2 \%$ dried & $24.2 \%$ as received \\
\hline Bulk Density & $937 \mathrm{lbs} / \mathrm{yd}^{3}$ & \\
\hline Carbon & $23.6 \%$ dried & $9.63 \%$ as received \\
\hline Carbon:Nitrogen Ratio & & 12.1 \\
\hline
\end{tabular}

to allow water to flow out and be collected in barrels. Horse manure 8 inches thick was filled onto each table and watered twice heavily before the worms, Eiseia fetida, were introduced. The worms were allowed to feed and reproduce for 1 month before extract was collected for application. The extract was mixed with water at a 1 to 1 ratio and applied to the trees with a 5-gallon Solo backpack foliar sprayer.

Vermicompost extract applications commenced on April 2, 2010 and were applied every two weeks through April 2011. The extract was applied to the 24 WNO 
trees included in the C+VEF, LCC+VEF, and VEF treatments. Thirty gallons of VEF was sprayed on each WNO tree in the course of the experiment. Vermicompost extract was analyzed by FGL (Table 5).

The legume cover crop (LCC) treatment consisted of two plantings. On April 20, 2010 black-eyed pea (Vigna unguiculata) seed was planted and the above ground biomass incorporated into the soil on August 7, 2010 with a machete, hoe, and shovel at a shallow depth so as not to disturb tree roots. On January 5, 2011 faba bean (Vicia faba) and dry pea (Pisum sativum L.) were planted and both were turned in on March 31, 2011. The LCC seed was hand broadcasted at the base of the trees from trunk to drip-line at a rate of roughly 72 seeds per square foot.

\section{Sampling Procedures}

The experiment consisted of four treatments: compost and vermicompost extract foliar (C+VEF) applications, legume cover crop, and VEF applications (LCC+VEF), VEF applications, and a control. Each treatment had 8 replicates; one replicate equaled one WNO tree. Leaf, soil, and fruit samples were taken and analyzed by FGL after the treatments had been implemented for one year. Sampling methods were based on FGL's protocol (Fruit Growers Laboratory, Inc., 2011).

Leaf samples were taken on May 23, 2011. Ten leaves were taken from each WNO experiment tree and sent to FGL for analysis as 4 composite samples representing each of the treatments. The leaves taken were from non-fruiting, non-flushing terminal 
Table 5. Vermicompost Extract Analysis and Pounds of Nutrient Applied per Washington Navel Orange Tree in the VEF Treatment of the Experiment. VEF stands for vermicompost extract foliar.

\begin{tabular}{|l|c|c|}
\hline Test Description & Pounds Per Acre-Foot & Pounds Applied Per Tree \\
\hline Calcium & 340 & 0.36 \\
\hline Magnesium & 330 & 0.35 \\
\hline Potassium & 5,300 & 5.67 \\
\hline Sodium & 2,100 & 2.24 \\
\hline Carbonate & 160 & 0.17 \\
\hline Bicarbonate & 8,800 & 9.4 \\
\hline Sulfate & 820 & 0.88 \\
\hline Chloride & 4,700 & 5.02 \\
\hline Nitrate & 730 & 0.78 \\
\hline Fluoride & 0 & 0 \\
\hline Boron & 5.4 & 0.0057 \\
\hline Copper & 0.14 & 0.00014 \\
\hline Iron & 1.8 & 0.0019 \\
\hline Zinc & 0.6 & 0.00064 \\
\hline TDS & 2,300 & 2.46 \\
\hline pH & 8.3 & \\
\hline E.C. & $11,500 \mathrm{umhos} / \mathrm{cm}$ & \\
\hline SAR & $12 \mathrm{mg} / \mathrm{l}$ & \\
\hline
\end{tabular}

shoots and washed before transport. Samples were refrigerated and sent to FGL two weeks after sampling.

Soil samples were taken on April 27, 2011. Core samples 18 inches deep were taken at the drip-line of each WNO tree in the experiment. Composite samples representing each of the four treatments were mixed in a bucket and one quart of soil was then submitted for analysis.

All fruit from the 32 WNO trees was harvested in late April, counted, and weighed. The data was statistically analyzed using a one-way analysis of variance to 
determine differences in harvest quantities and fruit sizes between the treatments. Mean separation was done using the Tukey-Kramer HSD. Tree height and circumference were measured in order to attempt to separate tree size from fruit yield results. Each tree height was determined with a measuring tape attached to a pole. While one person eyed the top of the tree with the top of the pole, another person brought the two to level, then the tree height from the ground to the top was recorded. Tree circumference was measured by placing a rope around the drip-line, marking the spot in the rope where the end met the circumference completion, then straightening out the rope and measuring it in meters. Two oranges from each treatment were analyzed for nutrient content by FGL and the data was charted. The very small sample was the result of the complete sample being confiscated at the US/Mexico border by U.S. Homeland Security border officials. 


\section{CHAPTER 4}

Results and Discussion

Soil and Leaf Analysis

The important trends demonstrated by the experiment were an increase in soil nitrogen, phosphorus, potassium, calcium in solution, zinc, moisture percentage, saturation, and organic matter percentage by the $\mathrm{C}+\mathrm{VEF}$ treatment (Table 6.). The control treatment had low or deficient values in these soil nutrients and soil qualities. The effects on soil nutrient levels and soil properties resulting from the C+VEF treatment suggest greater availability of water and nutrients for WNO tree uptake year round.

Leaf nutrient analysis showed increases in nitrogen, potassium, and zinc by the $\mathrm{C}+\mathrm{VEF}$ treatment compared to the control (Table 7). The VEF and LCC+VEF treatments added nitrogen and potassium compared to the control.

Following Tables 6 and 7, results of the leaf tissue and soil analyses are discussed in regards to treatment effect and implications for WNO tree nutrient uptake. All nutrient values refer to the data found in Tables 6 and 7. All descriptions of values are in accordance with FGL standards. Soil descriptions include very low, moderately low, optimum, moderately high, and very high while leaf nutrient content descriptions usually consist of deficient, low, ample, high, and excessive. 
Table 6. Effects of Four Nutrition Treatments on Soil Properties. Fruit Growers Laboratory, Inc. (FGL) optimum ranges provided for reference. C stands for compost; VEF stands for vermicompost extract foliar; and LCC stands for legume cover cropping.

\begin{tabular}{|c|c|c|c|c|c|}
\hline Treatments & $\mathrm{C}+\mathrm{VEF}$ & $\mathrm{LCC}+\mathrm{VEF}$ & VEF & Control & $\begin{array}{c}\text { FGL Optimum } \\
\text { Ranges }\end{array}$ \\
\hline \multicolumn{6}{|c|}{ Nutrient Values in Units of Pounds per Acre-Foot } \\
\hline Nitrate-Nitrogen & 96.4 & 41.6 & 19.6 & 23.2 & $40-80$ \\
\hline Phosphorus $\mathrm{P}_{2} \mathrm{O}_{5}$ & 651 & 64 & 55 & 64 & $140-280$ \\
\hline Potassium- $\mathrm{K}_{2} \mathrm{O}$ (Exch) & 4,500 & 2,600 & 2,300 & 2,410 & $600-3,600$ \\
\hline Potassium- $\mathrm{K}_{2} \mathrm{O}(\mathrm{Sol})$ & 218 & 75.4 & 66.7 & 65.2 & $94-470$ \\
\hline Calcium (Exch) & 18,800 & 1,700 & 18,500 & 18,600 & $15,000-20,000$ \\
\hline Calcium (Sol) & 374 & 147 & 169 & 159 & $160-640$ \\
\hline Magnesium (Exch) & 4,420 & 3,800 & 4,090 & 4,120 & $1,500-3,100$ \\
\hline Magnesium (Sol) & 226 & 89.9 & 105 & 95.3 & $73-220$ \\
\hline Sodium (Exch) & 1,280 & 1,120 & 1,160 & 1,180 & $0-1,400$ \\
\hline Sodium (Sol) & 956 & 693 & 748 & 700 & $0-740$ \\
\hline Sulfate & 359 & 174 & 207 & 173 & $120-3,800$ \\
\hline Zinc & 5.6 & 1.2 & 0.8 & 0.8 & 4-160 \\
\hline Manganese & 28.4 & 17.2 & 18.8 & 19.2 & $6-240$ \\
\hline Iron & 21.6 & 16.4 & 18.8 & 20 & $40-200$ \\
\hline Copper & 2.4 & 2.4 & 2 & 2.4 & $1.2-41$ \\
\hline Boron & 3 & 1.48 & 1.32 & 1.32 & $1.2-8.4$ \\
\hline Chloride & 478 & 485 & 525 & 396 & $14-660$ \\
\hline \multicolumn{6}{|l|}{ Soil Properties } \\
\hline CEC (meq/100g) & 36.3 & 31.6 & 34 & 34.2 & $14-35$ \\
\hline $\mathrm{pH}$ & 7.92 & 8.1 & 8.18 & 8.16 & $6-7.5$ \\
\hline Soil Salinity (mmhos/cm) & 1.69 & 1.12 & 1.22 & 1.10 & $0-2$ \\
\hline SAR & 4.8 & 5.6 & 5.6 & 5.4 & $0-6$ \\
\hline \multicolumn{6}{|l|}{ Units in Percentages } \\
\hline CEC-Calcium & 64.50 & 67.10 & 67.90 & 67.80 & $60-80$ \\
\hline CEC-Magnesium & 25.10 & 24.70 & 24.80 & 24.80 & $10-20$ \\
\hline CEC-Potassium & 6.67 & 4.37 & 3.59 & 3.74 & $1-6$ \\
\hline CEC-Sodium & 3.83 & 3.86 & 3.71 & 3.74 & $0-5$ \\
\hline Limestone & 1.40 & 0.9 & 1.40 & 1.00 & $0-0.5$ \\
\hline Moisture & 12.20 & 7.40 & 6.50 & 7.20 & $3.4-24$ \\
\hline Saturation & 43.00 & 30.70 & 33.10 & 34.20 & $40-50$ \\
\hline Organic Matter & 3.76 & 1.23 & 1.39 & 1.43 & \\
\hline
\end{tabular}


Table 7. Effects of Four Nutrition Treatments on Leaf Tissue Analysis of Washington Navel Orange Trees. Fruit Growers Laboratory, Inc. (FGL) optimum ranges provided for reference. C stands for compost; VEF stands for vermicompost extract foliar; and LCC stands for legume cover cropping.

\begin{tabular}{|l|c|c|c|c|c|}
\hline \multicolumn{7}{|c|}{ Treatments } & C+VEF & LCC+VEF & VEF & Control & $\begin{array}{c}\text { FGL Optimum } \\
\text { Ranges }\end{array}$ \\
\hline Units in Percentages \\
\hline Leaf Macronutrient & & & & & \\
\hline Total Nitrogen & 2.60 & 2.48 & 2.33 & 1.89 & $2.60-2.80$ \\
\hline Phosphorus & 0.53 & 0.51 & 0.42 & 0.56 & $0.12-0.21$ \\
\hline Potassium & 1.38 & 1.64 & 1.54 & 1.21 & $0.70-3.30$ \\
\hline Calcium & 4.14 & 3.69 & 3.78 & 4.64 & $3.00-5.50$ \\
\hline Magnesium & 0.41 & 0.38 & 0.40 & 0.42 & $0.26-0.60$ \\
\hline Sodium & 0.22 & 0.15 & 0.23 & 0.12 & $0.00-0.16$ \\
\hline Units in Parts Per Million & & & & \\
\hline Leaf Micronutrient & & & & & $25-200$ \\
\hline Zinc & 16.5 & 16.3 & 14.6 & 15 & $25-300$ \\
\hline Manganese & 19 & 22 & 22 & 22 & $60-200$ \\
\hline Iron & 44 & 43 & 45 & 46 & $5-40$ \\
\hline Copper & 12 & 11 & 10 & 11 & $31-300$ \\
\hline Boron & 160 & 134 & 143 & 182 &
\end{tabular}

\section{Nutrients}

Results of soil and leaf analysis are as follows.

\section{Nitrate-Nitrogen}

Nitrate-nitrogen soil levels of the control and VEF treatments were similarly low at 23.2 and 19.6 pounds per acre-foot respectively. This result is understandable since no amendment was applied to the soil under these treatments. The LCC+VEF treatment reported a nitrate-nitrogen level of 41.6 pounds per acre-foot, which is in the FGL optimum range. The increased nitrate-nitrogen level of the LCC treatment in comparison to the control and VEF treatments is a reflection of the nitrogen fixation capacity of the 
leguminous cover crops planted in the treatment. The C+VEF treatment demonstrated the highest level of nitrate-nitrogen, 96.4 pounds per acre-foot, which is in the FGL moderately high range.

The FGL optimum range of leaf nitrogen is between $2.6 \%$ and $2.8 \%$. The control had a deficient level at 1.9\%. The VEF and LCC+VEF treatments had low leaf nitrogen at $2.33 \%$ and $2.48 \%$ respectively. The $\mathrm{C}+\mathrm{VEF}$ treatment had a leaf nitrogen value inside the optimum range at $2.6 \%$.

The 45 cubic feet of compost amendment applied to each WNO tree during the course of the experiment contained 3.5 pounds of total nitrogen, which partly explains the high quantity of nitrate-nitrogen in the C+VEF treatment soil and the increase in leaf tissue nitrogen percentage. The increased soil nitrate-nitrogen and organic matter will provide available nitrogen for WNO tree uptake into the future with limited loss to leaching, runoff, or denitrification. The enhancement of microbial life in the soil as a result of applied compost may have acted to mobilize soil nitrogen to some degree. Further soil and leaf sampling and testing is necessary for understanding the length of time this nutrient availability will continue.

Phosphorus

Phosphorus- $\mathrm{P}_{2} \mathrm{O}_{5}$ levels were similarly low in soil of the control, LCC, and VEF treatments at 64, 64, and $55 \mathrm{lbs} / \mathrm{AF}$ respectively. The phosphorus- $\mathrm{P}_{2} \mathrm{O}_{5}$ level in the soil of the $\mathrm{C}+\mathrm{VEF}$ treatment was very high at $651 \mathrm{lbs} / \mathrm{AF}$. All treatments had leaf phosphorus levels categorized as excessive by FGL standards. Fruit degreening was slow and incomplete which may be due to phosphorus toxicity. Phosphorus toxicity retards 
degreening and accentuates regreening of fruit (Smith, 1966b). Citrus leaf phosphorus and nitrogen levels have an inverse effect on each other (Davies and Albrigo, 1998). Nitrogen added to the C+VEF and LCC+VEF treatment soils may be expected to reduce phosphorus leaf levels over time. Another sampling and testing of both soils and leaf tissue is required to fully understand the effects of the treatments on long-term phosphorus levels.

Potassium

Exchangeable potassium- $\mathrm{K}_{2} \mathrm{O}$ levels in the soil of the control, VEF, and LCC+VEF were similar and optimum at 2,410, 2,300, and 2,600 lbs/AF respectively. Exchangeable nutrients are positively or negatively charged ions bound to soil particles by opposing charges. Nutrients in the soil solution are part of the aqueous liquid portion of the soil and are not bound to soil particles or other soluble materials. Exchangeable nutrients and nutrients in the soil solution are available for plant uptake although nutrients in solution are more readily available and exchangeable nutrients are in reserve. The exchangeable potassium level in the soil of the C+VEF treatment was moderately high at 4,550 lbs/AF. Potassium- $\mathrm{K}_{2} \mathrm{O}$ in solution of the soils in the control, $\mathrm{LCC}+\mathrm{VEF}$, and VEF treatments was moderately low at 65.2, 75.4, and $66.7 \mathrm{lbs} / \mathrm{AF}$, respectively. The C+VEF treatment had a level of $\mathrm{K}_{2} \mathrm{O}$ in the soil solution of $218 \mathrm{lbs} / \mathrm{AF}$, which is within the optimum range. All treatments had potassium leaf tissue levels inside the optimum range. 


\section{Calcium}

Exchangeable calcium levels of all treatments were in the FGL optimum range. The exchangeable calcium level in the soil of the LCC+VEF treatment may have been slightly lower due to the calcium uptake by the cover crops and was not reincorporated back into the soil. The levels of calcium in solution in the soil of the LCC+VEF, VEF, and control treatments reported similar values at 147, 169, and $159 \mathrm{lbs} / \mathrm{AF}$ respectively. The C+VEF treatment had an amount of $374 \mathrm{lbs} / \mathrm{AF}$ of calcium in solution. The C+VEF treatment produced more than twice the amount of calcium in soil solution than any of the other treatments due to the fact that the compost amendment contained $46.6 \mathrm{lbs}$ of calcium per ton. The microbial processes present in the compost may have increased the level of calcium in the soil solution. All treatments had calcium leaf tissue levels inside the optimum range.

\section{Magnesium}

The levels of exchangeable magnesium in the soils of the VEF and control treatments were similar at 4,090 and 4,120 lbs/AF respectively, whereas the LCC+VEF treatment had a slightly lower amount of exchangeable Mg at 3,800 lbs/AF. This may be due to cover crop uptake of the nutrient and the plant material was not reincorporated back into the soil by the time of soil sampling. The C+VEF treatment had a slightly higher amount of exchangeable Mg at 4,420 lbs/AF. The levels of Mg in solution of the soils in the LCC, VEF, and control treatments had similar amounts at 89.9, 105, and 95.3 lbs/AF, whereas the C+VEF treatment had an amount of 226 lbs/AF. All treatments had leaf magnesium levels inside the FGL standard optimum range. 
Sodium

All four treatments had soil exchangeable sodium levels inside the FGL optimum range. The LCC+VEF and control treatments had similar values of sodium in solution inside the FGL optimum range for NWO production. The VEF treatment had a soil sodium in solution value slightly higher than the optimum range and the C+VEF treatment had a high level of sodium in solution.

The leaf sodium percentages of the control and LCC+VEF treatment were inside the FGL standard optimum range at $0.12 \%$ and $0.15 \%$ respectively. The VEF and $\mathrm{C}+\mathrm{VEF}$ treatments had high leaf sodium values at $0.23 \%$ and $0.22 \%$ respectively. The high level of sodium in the vermicompost extract shown in the vermicompost extract analysis likely increased the level of sodium in the leaf tissue.

Sulfate

All treatments had soil sulfate levels inside the FGL optimum range. Sulfate was not tested in the leaf analysis.

Zinc

The zinc levels in the soils of the LCC+VEF, VEF, and control treatments had similar values at 1.2, 0.8 , and $0.8 \mathrm{lbs} / \mathrm{AF}$, respectively, and all are considered very low according to FGL. The C+VEF treatment boosted the amount of zinc in the soil to 5.6 lbs/AF, which is considered optimum by FGL. The LCC+VEF, VEF, and control treatment zinc values are considered very low according to FGL.

The leaf zinc levels of all treatments were below the optimum range. The VEF and control treatment zinc levels were categorized as deficient at $14.6 \mathrm{ppm}$ and $15 \mathrm{ppm}$, 
respectively. The $\mathrm{LCC}+\mathrm{VEF}$ and $\mathrm{C}+\mathrm{VEF}$ treatments were categorized as low at 16.3 ppm and 16.6 ppm, respectively, but both treatments still allow for greater uptake potential for WNO trees than the other two treatments.

Manganese

All treatments resulted in optimum levels of soil manganese. However, all treatments had leaf levels that were categorized as low.

Iron

The LCC+VEF, VEF, and control treatments had very low levels of soil iron as evaluated by FGL. The C+VEF treatment had a moderately low amount of soil iron. All treatments had levels of iron in the leaves that were categorized as low.

\section{Copper}

All treatments had optimum levels of copper in the soil as well as in the leaves.

Boron

All treatments also had optimum levels of boron in the soil as well as the leaves.

Chloride

Levels of chloride were inside the FGL optimum range for all treatments.

Chloride levels were not tested in the leaves.

\section{Soil Properties}

All treatments had soil pH values categorized as moderately alkaline by FGL standards. The $\mathrm{C}+\mathrm{VEF}$ treatment reported the lowest $\mathrm{pH}$ value at 7.92 and the 
LCC+VEF, VEF, and control treatments had soil $\mathrm{pH}$ values of 8.10, 8.18, and 8.16, respectively.

The soil salinity levels of the treatments were similar and were categorized as satisfactory by FGL. The animal manures used in the compost may have slightly increased the soil salinity of the C+VEF treatment.

The sodium absorption ratio (SAR) values of the LCC+VEF, VEF, and control treatments were similar at 5.6, 5.6, and 5.4 respectively. The C+VEF treatment had a slightly lower SAR value at 4.8. All treatment SAR values were categorized as satisfactory by FGL. The slightly lower SAR level of C+VEF treatment reflects the greater amounts of added calcium and magnesium to the soil solution in relation to sodium.

The limestone percentages in the treatment soils were $0.9 \%$ and $1 \%$ in the $\mathrm{LCC}+\mathrm{VEF}$ and control treatments, respectively, and 1.4\% in both the C+VEF and VEF treatments. All treatments had high soil limestone percentages categorized as a possible problem by FGL standards. No lime inputs were required. The high limestone percentages of the treatment soils directly reflect the prominence of limestone in the soil parent material.

The soil moisture percentages of the treatments all were in the optimum range for WNO production according to FGL standards. Moisture percentage is a measurement of the soil sample weight as received and after drying to determine the percentage of water content in the soil. The higher soil moisture percentage of the C+VEF treatment made more water available for WNO tree uptake during hot, arid conditions of summer and early fall. 
The soil water saturation percentages of the treatments are low according to FGL standards in the LCC+VEF, VEF, and control treatments and optimum in the C+VEF treatment. The soil saturation percentage is a measurement of the dry weight of the sample and the amount of water necessary for complete saturation of soil pores, and reflects soil texture, which affects water holding capacity. The greater water saturation percentage of the soil in the $\mathrm{C}+\mathrm{VEF}$ treatment allowed WNO trees more capacity for water uptake.

The percentage of soil organic matter in the LCC+VEF, VEF, and control treatments had similar values at $1.28,1.39$, and 1.43 respectively. The slightly lower value of the LCC+VEF treatment reflects the organic matter consumed by soil microbes as the fixed nitrogen on the root nodules of the leguminous cover crop breaks down. The cover crops were incorporated minimally with a shovel and hoe so as not to disturb the roots of the trees. Thus, most of the above ground plant material was effectively a mulch so it likely did not contribute to soil organic matter. The C+VEF treatment had the highest organic matter percentage at 3.76\%.

The nitrogen to potassium ratios in the leaves of the treatments was 1.5 for the LCC+VEF, VEF, and control treatments, and 1.9 in the C+VEF treatment (Table 7). The optimum range of $\mathrm{N}: \mathrm{K}$ ratios is 1.6 to 2.2 with nitrogen percentage greater than $1.8 \%$ and potassium greater than 0.9\% (Davies and Albrigo, 1998). All treatments had nitrogen and potassium percentages above $1.8 \%$ and $0.9 \%$, respectively. 


\section{Fruit Yield and Fruit Nutrient Content}

There were significant differences in fruit yield among treatments. The C+VEF treatment had a significantly greater fruit yield (Figure 1; Appendix B, page 75) and number of fruit per treatment (Figure 2; Appendix B, page 77) than the other treatments. There were no significant differences in fruit yield and number among the LCC+VEF, VEF, and control treatments. No significant difference was found in fruit size among all four treatments (Figure 3; Appendix B, page 79).

\section{CON}

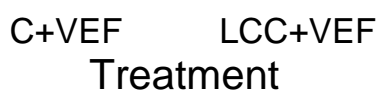

VEF

Fig. 1. Effect of Four Nutrient Treatments on Washington Navel Orange Yield. The boxplot graph shows sample minimum, lower quartile, median, upper quartile, and sample maximum. The $\mathrm{x}$-axis treatments are: CON (control), C+VEF (compost and vermicompost extract foliar applications), LCC+VEF (legume cover cropping and vermicompost extract foliar applications), and VEF (vermicompost extract foliar applications). 


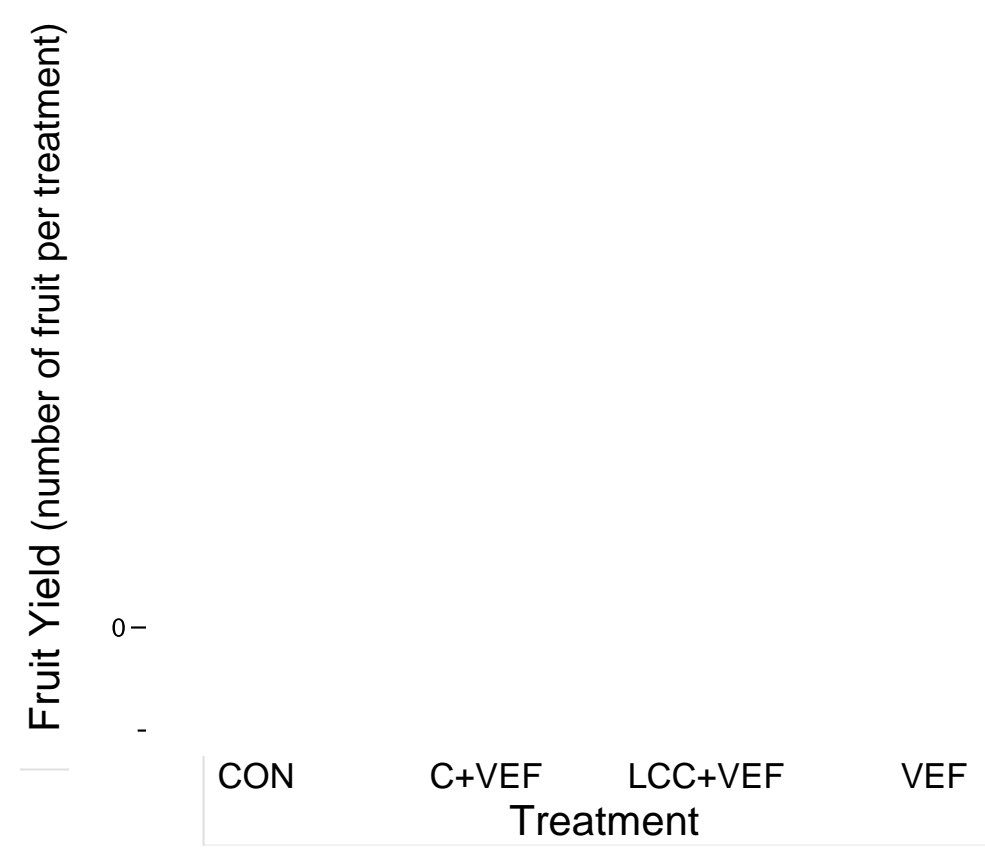

Fig. 2. Effect of Four Nutrient Treatments on Washington Navel Orange Yield. The boxplot graph shows sample minimum, lower quartile, median, upper quartile, and sample maximum. The x-axis treatments are: CON (control), C+VEF (compost and vermicompost extract foliar applications), LCC+VEF (legume cover cropping and vermicompost extract foliar applications), and VEF (vermicompost extract foliar applications).

The results of measurements taken on tree height (Figure 4; Appendix B, page 80) and circumference (Figure 5; Appendix B, page 80) indicated no significant difference among treatments. These measurements were taken to isolate WNO fruit yield from tree size.

The effect of the four nutrition treatments on fruit yield, expressed this time as pounds per tree, were compared with nutrient output (nutrient removal due to yield), which was calculated from the data (Table 8). Nutrient output results were based upon a compromised sampling due to confiscation. The C+VEF treatment apparently had a greater removal of nutrients as a result of yield than the other treatments, but statistical 
analysis was not conducted. The overall production performance of the C+VEF treatment may have been enhanced due to the added nitrogen and potassium made available for uptake by the compost during phase 1 and 2 of fruit development.

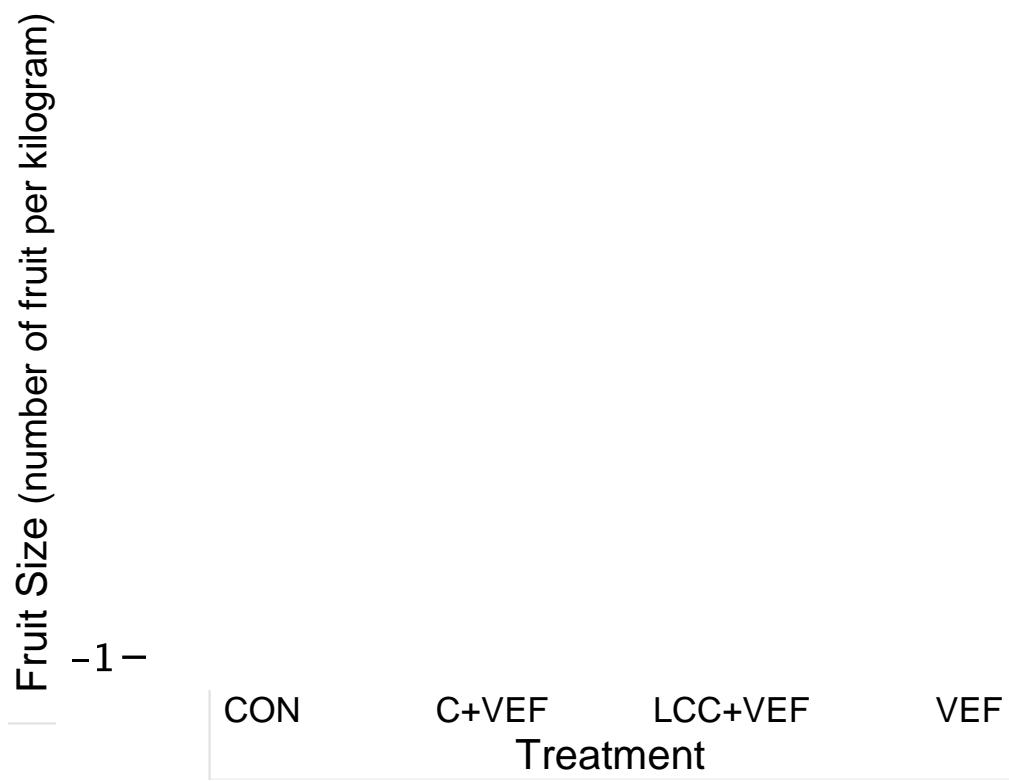

Fig. 3. Effect of Four Nutrient Treatments on Fruit Size of Washington Navel Orange. The boxplot graph shows sample minimum, lower quartile, median, upper quartile, and sample maximum. The x-axis treatments are: CON (control), C+VEF (compost and vermicompost extract foliar applications), LCC+VEF (legume cover cropping and vermicompost extract foliar applications), and VEF (vermicompost extract foliar applications). 


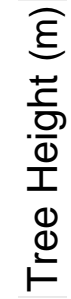

$2-$

CON

$C+V E F \quad$ LCC+VEF VEF

Treatment

Fig. 4. Height of Washington Navel Orange Trees Per Treatment, Measured at Harvest. The boxplot graph shows sample minimum, lower quartile, median, upper quartile, and sample maximum. The $\mathrm{x}$-axis treatments are: CON (control), C+VEF (compost and vermicompost extract foliar applications), LCC+VEF (legume cover cropping and vermicompost extract foliar applications), and VEF (vermicompost extract foliar applications). 


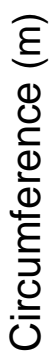

$5-$

CON C+VEF LCC+VEF VEF Treatment

Fig. 5. Circumference of Washington Navel Orange Trees Per Treatment, Measured at Harvest. The boxplot graph shows sample minimum, lower quartile, median, upper quartile, and sample maximum. The $\mathrm{x}$-axis treatments are: CON (control), C+VEF (compost and vermicompost extract foliar applications), LCC+VEF (legume cover cropping and vermicompost extract foliar applications), and VEF (vermicompost extract foliar applications).

Table 8. Effect of Four Nutrition Treatments on Mean Fruit Yield and Mean Nutrient Output of Washington Navel Orange Trees. Average of Each Treatment. C stands for compost; VEF stands for vermicompost extract foliar; and LCC stands for legume cover cropping.

\begin{tabular}{|l|l|l|l|l|}
\hline \multicolumn{1}{|c|}{ Treatments } & C+VEF & LCC+VEF & \multicolumn{1}{c|}{ VEF } & Control \\
\hline Units in Pounds Per Tree & \multicolumn{5}{|c|}{} \\
\hline Fruit Yield & 28.3 & 7.3 & 5.6 & 8.48 \\
\hline Nutrient Output & & & & \\
\hline Nitrogen & 0.094 & 0.013 & 0.011 & 0.025 \\
\hline Phosphorus & 0.095 & 0.0025 & 0.0048 & 0.0061 \\
\hline Potassium & 0.122 & 0.02 & 0.026 & 0.033 \\
\hline Calcium & 0.056 & 0.015 & 0.009 & 0.011 \\
\hline Magnesium & 0.012 & 0.0018 & 0.0025 & 0.003 \\
\hline Sodium & 0.0023 & 0.00075 & 0.00028 & 0.00048 \\
\hline Boron & 0.00033 & 0.000063 & 0.000057 & 0.000072 \\
\hline Copper & 0.0009 & 0.000037 & 0.000038 & 0.000048 \\
\hline Iron & 0.00078 & 0.000075 & 0.000052 & 0.000061 \\
\hline Manganese & 0.00056 & 0.000012 & 0.0000093 & 0.000012 \\
\hline
\end{tabular}

Page 36 
In terms of the performance of the different treatments to compensate for nutrient removal due to fruit harvest, the $\mathrm{C}+\mathrm{VEF}$ treatment added the most nutrients to the soil and improved soil qualities for WNO tree uptake of nutrients for future crops more than the other treatments (Table 6). The LCC+VEF treatment doubled the amount of soil nitrate-nitrogen of that in the control treatment, but organic matter and CEC decreased.

The VEF treatment added leaf nitrogen for tree growth and increased sodium levels to the high range. Further research is needed to develop a vermicompost extract for WNO leaf surfaces that would lower sodium levels and increase other nutrients.

Further research is needed to fully understand the potential of mineralized nutrients realized by increased microbial activity in the soil stimulated as a result of compost applications. Humic acid levels of compost may aid in nutrient uptake and testing humic acid in the treatment soils may provide a better understanding of the contribution of compost applications on WNO tree nutrient uptake (Canellas et al., 2002).

The percentage of total soluble solids (TSS) of all treatments exceeded the $10 \%$ to 20\% range for fresh fruit stated by (Davies and Albrigo, 1998) to be indicative of high quality. The TSS percentages of the treatments showed C+VEF 28\%, LCC+VEF 21.9\%, VEF $24.6 \%$ and the control 25.1\%. Fruit TSS contains carbohydrates, organic acids, proteins, fats and various minerals (Davies and Albrigo, 1998). 


\section{CHAPTER 5}

\section{Conclusions and Recommendations}

The optimum levels of all nutrients are required for WNO trees to produce maximum yields. The experiment showed that compost applications can supply sufficient nutrients to increase yields for WNO trees. Legume cover crops did not supply nutrients required to increase yield during the experiment but did increase soil and leaf nitrogen content. Vermicompost extract also did not increase yield but did increase leaf nitrogen content. All the treatments have their merit and can be effective nutrient contributors to WNO production with the correct application.

Compost applications were proven to increase WNO fruit yield, soil and leaf nutrient content, and enhance soil properties that could improve nutrient uptake for future crops. The increases in soil organic matter, soil moisture, and saturation as a result of the compost applications will provide a substantial amount of available water and nutrients for WNO trees in the hot, dry summer and early-fall season when the orchard is irrigated once every three weeks. Another sampling of the soil and leaves in 2012 would help determine the amount of nutrient uptake by the WNO trees as a result of the compost applications and the rate of nutrient dispersion in the soil. This information could be used to monitor nutrient levels. If the nutrient levels remain the same or increase then the compost application rate could be reduced to once every 6 months or a year to maintain optimum levels. It is important to apply compost frequently at first to establish optimum nutrient content and improve soil properties and then reduce application rates to maintain optimum levels. Testing the soil microbial activity and humic acid levels could further 
the understanding of nutrient availability for WNO tree uptake as a result of the applied compost.

The legume cover crop was not incorporated into the soil sufficiently enough to increase soil nutrient levels, except for nitrogen, or soil organic matter, thus fruit yield did not increase. The added nitrogen provided by root nodules of the nitrogen-fixing crops may have been responsible for increased nitrogen content in the leaves and the decrease in organic matter. A more thorough incorporation of the cover crops would have been a great disturbance to the shallow roots of the WNO trees. Planting the cover crop in the orchard alleys would allow space for proper incorporation into the soil and thus the potential benefits of the cover crop as green manure could be realized. The current management uses the orchard alleys for livestock feed and periodically lets the alleys go fallow. The cover crop cultivars used in the experiment are traditionally planted and harvested as a food crop and field residues are used for livestock feed. Incorporating these residues into the soil would increase soil nutrient content and improve soil properties.

Vermicompost extract foliar applications did provide WNO trees with increased leaf nitrogen content compared to the control, but did not provide enough nutrients to increase yield. Vermicompost extract could be most effective applied twice a week during phase 1 of WNO fruit development when nutrient requirement for fruit development is at its peak. The quality of the extract could be improved by aeration and by using finished compost to feed the worms. Further experimentation with extract quality and timing of foliar applications on WNO trees is required to determine the potential benefits. 
A great diversity of microorganisms are ingested and distributed by worms throughout the soil environment. This includes both human pathogens and plant pathogens. Prior to vermicomposting, manures should be composted for a sufficient amount of time and at a sufficiently high temperature in order to eliminate these pathogenic microorganisms.

All nutrient enhancing strategies employed in the experiment were constructed onsite from materials derived onsite. The livestock manures and carbon materials used in the compost translated into increased yield in WNO trees with labor being the only farm expenditure. The cycling of nutrients inside a small, diversified farming system could increase productivity and improve efficiency of the farm as a whole.

In summary, the following recommendations stem from this research:

1) Another sampling of soil and leaves in 2012;

2) Compost application rates could be reduced to every six months or a year;

3) Testing the soil microbial activity and humic acid levels;

4) Planting the cover crop in orchard alleys; and

5) Further experimentation with vermicompost extract quality and timing of foliar applications. 


\section{References}

Alexander, M. 1977. Introduction to microbiology. Krieger Publishing Company, Malabar, Florida.

Canellas, L.P., F.L. Olivares, A.L. Okorokova-Facanha and A.R. Facanha. 2002. Humic acids isolated from earthworm compost enhance root elongation, lateral root emergence, and plasma membrane $\mathrm{H}+$-ATPase activity in maize roots. Plant Physiology. 130(4):1951-1957.

Comundu Municipal Census. 2008.

Davies, F.S. and L.G. Albrigo. 1998. Citrus. CAB International, Wallingford, UK.

Diacono, M. and F. Montemurro. 2010. Long-term effects of organic amendments on soil fertility. Agronomy for Sustainable Development. Apr-June, v. 30(2):401-422.

Douds Jr., D.D., L. Galvez, M. Franke-Synyder, C. Reider and L.E. Drinkwater. 1997. Effect of compost addition and crop rotation point upon VAM fungi. Agriculture, Ecosystems and Environment. 65:257-266.

Edwards, C.A. and P.J. Bohlen. 1996. Biology and ecology of earthworms. Chapman and Hall, Boundary Row, London, UK.

Fruit Growers Laboratory, Inc. 2011. Santa Paula, California.

Garcia, F. 1915. Peas as an orchard green manure and cover crop. Rio Grand Publishing Company, Las Cruces, New Mexico.

Gaskell, M., J. Mitchell, R. Smith, S. Koike and C. Fouche. 2000. Soil Fertility Management for Organic Crops. The Regents of the University of California, Division of Agriculture and Natural Resources, California. 


\section{References (continued)}

Hernandez, A., H. Castillo, D. Ojeta, A. Arras, J. Lopez and E. Sanchez. 2010. Effect of vermicompost and compost on lettuce production. Chilean Journal of Agriculture Research.

Ingham, E. 2005. The compost tea manual, 5th edition. Soil Foodweb Inc. Corvallis, Oregon.

Jouquet, E.P., E. Bloquel, T. Thu Doan, M. Ricoy, D. Orange, C. Rumpel and T. Tran Duc. 2011. Do compost and vermicompost improve macronutrient retention and plant growth in degraded tropical soils? Compost Science and Utilization. 19(1):15-24.

Kuepper, G. 2003. Manures for organic crop production, soil systems guide. ATTRANational Sustainable Agriculture Information Service. Fayetteville, Arkansas.

Ovalle C., A. del Pozo, M.B. Peoples and A. Lavin. 2010. Estimating the contribution of nitrogen nutrition from legume cover crops to the nitrogen nutrition of grapevines using a ${ }^{15} \mathrm{~N}$ dilution technique. Plant Soil. 334:247-259.

Plant, A.P., T.J. Radovich, N.V. Hue, S.T. Talcott and K.A. Krenek. 2009. Vermicompost extracts influence growth, mineral nutrients, phytonutrients and antioxidant activity in pak choi (Brassica rapa cv. Bonsai, Chinensis group) grown under vermicompost and chemical fertilizer. Journal of the Science of Food and Agriculture. 89:2383-2392.

Rodale, J.I. 1971. The complete book of composting. Rodale Books Inc. Emmaus, Pennsylvania. 


\section{References (continued)}

Singh, R., R.K. Gupta, R.T. Patil, R.R. Sharma, R. Asrey, A. Kumar and K.K. Jangra. 2009. Sequential foliar application of vermicompost leachates improves marketable fruit yield and quality of strawberry (Fragarria x ananassa Dutch).

Smith, P.F. 1966a. Citrus nutrition. Horticulture Publications, Rutgers State University, New Brunswick, New Jersey.

Smith, P.F. 1966b. Leaf analysis of citrus. Horticulture Publications, Rutgers State University, New Brunswick, New Jersey.

Storey, R. and M.T. Treeby. 2001. Nutrient uptake into navel oranges during fruit development. CSIRO Plant Industry, Horticulture Unit, Merbein Laboratory, Victoria Australia.

Sullivan, P. 2003. Overview of cover crops and green manures, fundamentals of sustainable agriculture. ATTRA Publication \#IP024.

Weir, R.G., D.B. Letham, P. Broadbent and P.J. Nicholls. 1978. The effect of phosphorus and vesicular-mycorrhizal development on growth of citrus in a sandmount series. Proceedings of the Intl. Society of Citriculture, June 15, 1980. pp 288-292. 


\section{Appendices}
A. Fruit Growers Laboratory, Inc. Soil, Leaf, Water, and Amendment Analysis Results
B. Statistical Analysis of Fruit Yield and Tree Size
C. Photo Essay of the Experiment 


\section{APPENDIX A}

Fruit Growers Laboratory, Inc. Soil, Leaf, Water, and Amendment Analysis Results 
June 27, 2011

Patty Frazer

102 Ravenhill Road

Orinda, CA 94563

Description : GMCC + VTF

Project :Payton Carling/Cal Poly Thesis
Lab ID : SP 1105923-002

Customer ID : 2-23787

Sampled On : May 23, 2011

Sampled By : Payton Carling

Received On : June 13, 2011

Depth : N/A

Meth Irrg. :

WASHINGTON SOIL ANALYSIS

\begin{tabular}{|c|c|c|c|c|c|c|c|c|}
\hline Test Description & Result & Units & Optimum Range & & Graphical & esults Pr & entation & \\
\hline Primary Nutrients & & & & $\begin{array}{l}\text { Very } \\
\text { Low }\end{array}$ & $\begin{array}{l}\text { Moderately } \\
\text { Low }\end{array}$ & Optimum & $\begin{array}{c}\text { Moderately } \\
\text { High }\end{array}$ & $\begin{array}{l}\text { Very } \\
\text { High }\end{array}$ \\
\hline $\begin{array}{l}\text { Nitrate-Nitrogen } \\
\text { Phosphorus- } \mathrm{P}_{2} \mathrm{O}_{5} \\
\text { Potassium-K2 } \mathrm{K}_{2} \mathrm{O} \text { (Exch) } \\
\text { Potassium- } \mathrm{K}_{2} \mathrm{O} \quad \text { (Sol) }\end{array}$ & $\begin{array}{c}41.6 \\
64 \\
2600 \\
75.4 \\
\end{array}$ & $\begin{array}{l}\mathrm{Lbs} / \mathrm{AF} \\
\mathrm{Lbs} / \mathrm{AF} \\
\mathrm{Lbs} / \mathrm{AF} \\
\mathrm{Lbs} / \mathrm{AF}\end{array}$ & $\begin{array}{c}40-80 \\
140-280 \\
600-3600 \\
94-470 \\
\end{array}$ & & $\square_{3 \%}$ & & & \\
\hline $\begin{array}{l}\text { Secondary Nutrients } \\
\text { Calcium (Exch) } \\
\text { Calcium (Sol) } \\
\text { Magnesium (Exch) } \\
\text { Magnesium (Sol) } \\
\text { Sodium (Exch) } \\
\text { Sodium (Sol) } \\
\text { Sulfate } \\
\end{array}$ & $\begin{array}{c}17000 \\
147 \\
3800 \\
89.9 \\
1120 \\
693 \\
174 \\
\end{array}$ & $\begin{array}{l}\mathrm{Lbs} / \mathrm{AF} \\
\mathrm{Lbs} / \mathrm{AF} \\
\mathrm{Lbs} / \mathrm{AF} \\
\mathrm{Lbs} / \mathrm{AF} \\
\mathrm{Lbs} / \mathrm{AF} \\
\mathrm{Lbs} / \mathrm{AF} \\
\mathrm{Lbs} / \mathrm{AF}\end{array}$ & $\begin{array}{c}15000-20000 \\
160-640 \\
1500-3100 \\
73-220 \\
0.0-1400 \\
0.0-740 \\
120-3800 \\
\end{array}$ & & & $16 \%$ & $\square$ & \\
\hline $\begin{array}{l}\text { Micro Nutrients } \\
\text { Zinc } \\
\text { Manganese } \\
\text { Iron } \\
\text { Copper } \\
\text { Boron } \\
\text { Chloride } \\
\end{array}$ & $\begin{array}{l}1.20 \\
17.2 \\
16.4 \\
2.40 \\
1.48 \\
485\end{array}$ & $\begin{array}{l}\mathrm{Lbs} / \mathrm{AF} \\
\mathrm{Lbs} / \mathrm{AF} \\
\mathrm{Lbs} / \mathrm{AF} \\
\mathrm{Lbs} / \mathrm{AF} \\
\mathrm{Lbs} / \mathrm{AF} \\
\mathrm{Lbs} / \mathrm{AF}\end{array}$ & $\begin{array}{l}4.0-160 \\
6.0-240 \\
40-200 \\
1.2-41 \\
1.2-8.4 \\
14-660 \\
\end{array}$ & & & & & \\
\hline $\mathrm{CEC}$ & 31.6 & $\mathrm{meq} / 100 \mathrm{~g}$ & $14-35$ & & & & & \\
\hline $\begin{array}{l}\text { \% Base Saturation } \\
\text { CEC - Calcium } \\
\text { CEC - Magnesium } \\
\text { CEC - Potassium } \\
\text { CEC - Sodium } \\
\text { CEC - Hydrogen }\end{array}$ & $\begin{array}{l}67.1 \\
24.7 \\
4.37 \\
3.86 \\
0.00\end{array}$ & $\begin{array}{l}\% \\
\% \\
\% \\
\% \\
\%\end{array}$ & $\begin{array}{l}60-80 \\
10-20 \\
1.0-6.0 \\
0.0-5.0 \\
0.0-3.0\end{array}$ & & & & & \\
\hline \multirow{2}{*}{ 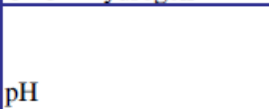 } & & & \multirow[b]{2}{*}{$6.0-7.5$} & $\begin{array}{c}\text { Strongly } \\
\text { Acidic }\end{array}$ & $\begin{array}{c}\text { Moderately } \\
\text { Acidic }\end{array}$ & $\begin{array}{c}\text { Near } \\
\text { Neutral }\end{array}$ & $\begin{array}{c}\text { Moderately } \\
\text { Alkaline }\end{array}$ & $\begin{array}{l}\text { Strongly } \\
\text { Alkaline }\end{array}$ \\
\hline & 8.10 & -- & & & & & & \\
\hline
\end{tabular}

Good $\quad$ Problem Indicates physical conditions and/or phenological and amendment requirements.

Note: Color coded bar graphs have been used to provide you with 'AT-A-GLANCE' interpretations.

\begin{tabular}{lllll}
\hline Corporate Offices \& Laboratory & Office \& Laboratory & Office \& Laboratory & Office \& Laboratory & Field Office \\
853 Corporation Street & 2500 Stagecoach Road & 563 East Lindo Avenue & 3442 Empresa Drive, Suite D & Visalia, California \\
Santa Paula, CA 93060 & Stockton, CA 95215 & Chico, CA 95926 & San Luis Obispo, CA 93401 & TEL: (559) 734-9473 \\
TEL: (805) 392-2000 & TEL: (209) 942-0182 & TEL: (530) 343-5818 & TEL: (805) 783-2940 & FAX: (559) 734-8435 \\
FAX: (805) 392-2063 & FAX: (209) 942-0423 & FAX: (530) 343-3807 & FAX: (805) 392-2063 & Mobile: (559) 737-2399
\end{tabular}


June 27, 2011

Lab ID : : SP 1105923-002

Patty Frazer

Customer ID : 2-23787

Description : GMCC + VTF

WASHINGTON SOIL ANALYSIS

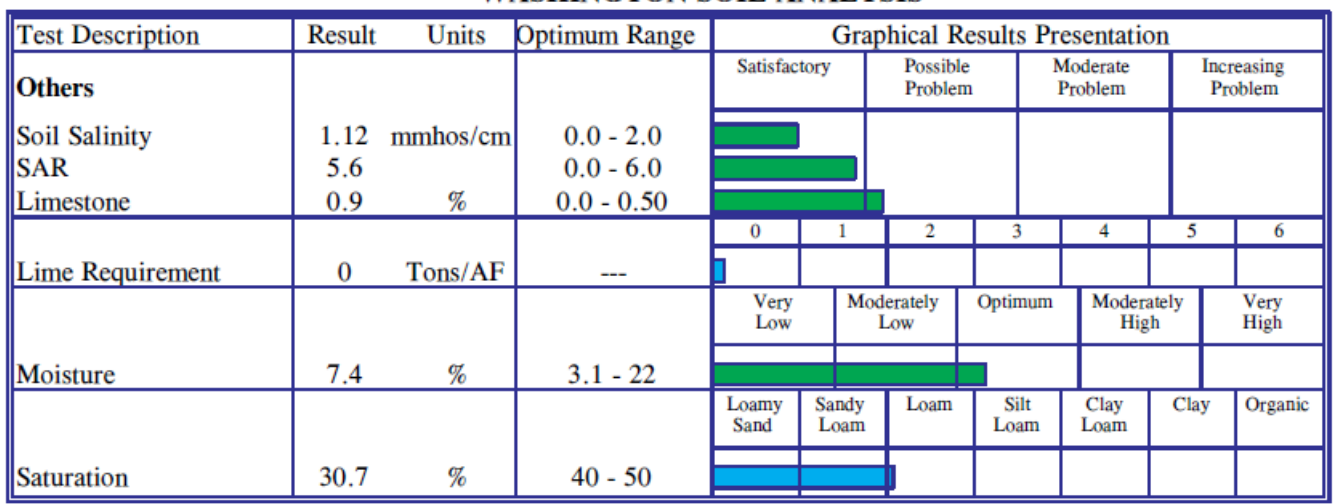

Good $\quad$ Problem Indicates physical conditions and/or phenological and amendment requirements.

Note: Color coded bar graphs have been used to provide you with 'AT-A-GLANCE' interpretations.

1) The need for soil Nitrate is dependant upon crop phenology (Growth Stage) and crop requirement. A soil Nitrate level of $10-40 \mathrm{ppm}$ is preferred for a short time during critical periods of uptake into the tree. It is highly desirable to have low soil Nitrate $(<5 \mathrm{ppm})$ prior to winter rainfall and cold soil conditions. Use the leaf Nitrogen level to determine primary Nitrogen requirement

2) Trifoliate \& Citrumelo rootstocks are very sensitive to limestone and should not be planted in soils containing limestone.

Other rootstock are moderately sensitive to limestone. Ascertain the rootstock tolerance prior to planting.

CEL:JRJ
FRUIT GROWERS LABORATORY, INC.

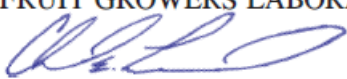

Chad Lessard, Director of Ag. Services 


\section{FRUIT GROWERS LABORATORY, INC.}

\section{Analytical Chemists}

www.fglinc.com

June 27, 2011

Patty Frazer

102 Ravenhill Road

Orinda, CA 94563

Description : VTF

Project :Payton Carling/Cal Poly Thesis
Lab ID : SP 1105923-003

Customer ID : 2-23787

Sampled On : May 23, 2011

Sampled By : Payton Carling

Received On : June 13, 2011

Depth :N/A

Meth Irrg. :

WASHINGTON SOIL ANALYSIS

\begin{tabular}{|c|c|c|c|c|c|c|c|c|}
\hline Test Description & Result & Units & Optimum Range & \multicolumn{5}{|c|}{ Graphical Results Presentation } \\
\hline Primary Nutrients & & & & $\begin{array}{l}\text { Very } \\
\text { Low }\end{array}$ & $\begin{array}{c}\text { Moderately } \\
\text { Low }\end{array}$ & Optimum & $\begin{array}{c}\text { Moderately } \\
\text { High }\end{array}$ & $\begin{array}{l}\text { Very } \\
\text { High }\end{array}$ \\
\hline Nitrate-Nitrogen & 19.6 & $\mathrm{Lbs} / \mathrm{AF}$ & $40-80$ & & & & & \\
\hline Phosphorus- $\mathrm{P}_{2} \mathrm{O}_{5}$ & 55 & $\mathrm{Lbs} / \mathrm{AF}$ & $140-280$ & & & & & \\
\hline Potassium- $\mathrm{K}_{2} \mathrm{O}$ (Exch) & 2300 & $\mathrm{Lbs} / \mathrm{AF}$ & $640-3800$ & & & & & \\
\hline Potassium- $\mathrm{K}_{2} \mathrm{O}$ (Sol) & 66.7 & $\mathrm{Lbs} / \mathrm{AF}$ & $94-470$ & & ]$_{3 \%}$ & & & \\
\hline Secondary Nutrients & & & & & & & & \\
\hline Calcium (Exch) & 18500 & $\mathrm{Lbs} / \mathrm{AF}$ & $16000-22000$ & & & & & \\
\hline Calcium (Sol) & 169 & $\mathrm{Lbs} / \mathrm{AF}$ & $160-640$ & & & $17 \%$ & & \\
\hline Magnesium (Exch) & 4090 & $\mathrm{Lbs} / \mathrm{AF}$ & $1600-3300$ & & & & $\square$ & \\
\hline Magnesium (Sol) & 105 & $\mathrm{Lbs} / \mathrm{AF}$ & $73-220$ & & & $17 \%$ & & \\
\hline Sodium (Exch) & 1160 & $\mathrm{Lbs} / \mathrm{AF}$ & $0.0-1600$ & & & & & \\
\hline Sodium (Sol) & 748 & $\mathrm{Lbs} / \mathrm{AF}$ & $0.0-800$ & & & & $4 \%$ & \\
\hline Sulfate & 207 & $\mathrm{Lbs} / \mathrm{AF}$ & $120-3800$ & & & & & \\
\hline Micro Nutrients & & & & & & & & \\
\hline Zinc & 0.800 & Lbs/AF & $4.0-160$ & & & & & \\
\hline Manganese & 18.8 & Lbs/AF & $6.0-240$ & & & & & \\
\hline Iron & 18.8 & Lbs/AF & $40-200$ & & & & & \\
\hline Copper & 2.00 & Lbs/AF & $1.2-41$ & & & & & \\
\hline Boron & 1.32 & $\mathrm{Lbs} / \mathrm{AF}$ & $1.2-8.4$ & & & & & \\
\hline Chloride & 525 & $\mathrm{Lbs} / \mathrm{AF}$ & $14-660$ & & & & & \\
\hline CEC & 34.0 & meq $/ 100 \mathrm{~g}$ & $14-35$ & & & & & \\
\hline$\%$ Base Saturation & & & & & & & & \\
\hline CEC - Calcium & 67.9 & $\%$ & $60-80$ & & & & & \\
\hline CEC - Magnesium & 24.8 & $\%$ & $10-20$ & & & & $\square$ & \\
\hline CEC - Potassium & 3.59 & $\%$ & $1.0-6.0$ & & & & & \\
\hline CEC - Sodium & 3.71 & $\%$ & $0.0-5.0$ & & & & & \\
\hline CEC - Hydrogen & 0.00 & $\%$ & $0.0-3.0$ & & & & & \\
\hline & & & & $\begin{array}{l}\text { Strongly } \\
\text { Acidic }\end{array}$ & $\begin{array}{l}\text { Moderately } \\
\text { Acidic }\end{array}$ & $\begin{array}{c}\text { Near } \\
\text { Neutral }\end{array}$ & $\begin{array}{c}\text { Moderately } \\
\text { Alkaline }\end{array}$ & $\begin{array}{l}\text { Strongly } \\
\text { Alkaline }\end{array}$ \\
\hline $\mathrm{pH}$ & 8.18 & - & $6.0-7.5$ & & & & & \\
\hline
\end{tabular}

Good $\quad$ Problem Indicates physical conditions and/or phenological and amendment requirements.

Note: Color coded bar graphs have been used to provide you with 'AT-A-GLANCE' interpretations.

\begin{tabular}{lllll}
\hline Corporate Offices \& Laboratory & Office \& Laboratory & Office \& Laboratory & Office \& Laboratory & Field Office \\
853 Corporation Street & 2500 Stagecoach Road & 563 East Lindo Avenue & 3442 Empresa Drive, Suite D & Visalia, California \\
Santa Paula, CA 93060 & Stockton, CA 95215 & Chico, CA 95926 & San Luis Obispo, CA 93401 & TEL: (559) 734-9473 \\
TEL: (805) 392-2000 & TEL: (209) 942-0182 & TEL: (530) 343-5818 & TEL: (805) 783-2940 & FAX: (559) 734-8435 \\
FAX: (805) 392-2063 & FAX: (209) $942-0423$ & FAX: (530) 343-3807 & FAX: (805) 392-2063 & Mobile: (559) 737-2399
\end{tabular}


June 27, 2011

Lab ID : : SP 1105923-003

Patty Frazer

Customer ID : 2-23787

Description : VTF

WASHINGTON SOIL ANALYSIS

\begin{tabular}{|c|c|c|c|c|c|c|c|c|c|c|}
\hline Test Description & \multirow{3}{*}{\multicolumn{2}{|c|}{\begin{tabular}{cc|} 
Result & Units \\
& \\
& \\
1.22 & $\mathrm{mmhos} / \mathrm{cm}$ \\
5.6 & \\
1.4 & $\%$
\end{tabular}}} & Optimum Range & \multicolumn{7}{|c|}{ Graphical Results Presentation } \\
\hline Others & & & \multirow{3}{*}{$\begin{array}{c}0.0-2.0 \\
0.0-6.0 \\
0.0-0.50 \\
\end{array}$} & \multicolumn{2}{|c|}{\begin{tabular}{l|l|l} 
Satisfactory & \\
\end{tabular}} & \multicolumn{2}{|c|}{\begin{tabular}{l|l} 
Possible \\
Problem
\end{tabular}} & $\begin{array}{l}\text { Moderate } \\
\text { Problem }\end{array}$ & \multicolumn{2}{|c|}{$\begin{array}{l}\text { Increasing } \\
\text { Problem }\end{array}$} \\
\hline $\begin{array}{l}\text { Soil Salinity } \\
\text { SAR } \\
\text { Limestone }\end{array}$ & & & & & & & & & & \\
\hline \multirow[b]{2}{*}{ Lime Requirement } & & & & 0 & 1 & 2 & $\frac{1}{3}$ & 4 & 5 & 6 \\
\hline & 0 & Tons/AF & $\ldots$ & & & & & & & \\
\hline \multirow[b]{2}{*}{ Moisture } & \multirow[b]{2}{*}{6.5} & \multirow[b]{2}{*}{$\%$} & \multirow[b]{2}{*}{$3.3-23$} & \multicolumn{3}{|c|}{\begin{tabular}{|c|}
$\begin{array}{c}\text { Moderately } \\
\text { Low }\end{array}$ \\
\end{tabular}} & Optimum & \multicolumn{2}{|c|}{$\begin{array}{c}\text { Moderately } \\
\text { High }\end{array}$} & $\begin{array}{l}\text { Very } \\
\text { High }\end{array}$ \\
\hline & & & & & & & & & & \\
\hline \multirow[b]{2}{*}{ Saturation } & \multirow[b]{2}{*}{33.1} & \multirow[b]{2}{*}{$\%$} & \multirow[b]{2}{*}{$40-50$} & $\begin{array}{l}\text { Loamy } \\
\text { Sand }\end{array}$ & $\begin{array}{l}\text { Sandy } \\
\text { Loam }\end{array}$ & Loam & $\begin{array}{c}\text { Silt } \\
\text { Loam }\end{array}$ & $\begin{array}{l}\text { Clay } \\
\text { Loam }\end{array}$ & Clay & Organic \\
\hline & & & & & & $\sqsupset$ & & & & \\
\hline
\end{tabular}

Good $\quad$ Problem Indicates physical conditions and/or phenological and amendment requirements.

Note: Color coded bar graphs have been used to provide you with 'AT-A-GLANCE' interpretations.

1) The need for soil Nitrate is dependant upon crop phenology (Growth Stage) and crop requirement. A soil Nitrate level of $10-40 \mathrm{ppm}$ is preferred for a short time during critical periods of uptake into the tree. It is highly desirable to have low soil Nitrate $(<5 \mathrm{ppm})$ prior to winter rainfall and cold soil conditions. Use the leaf Nitrogen level to determine primary Nitrogen requirement.

2) Trifoliate \& Citrumelo rootstocks are very sensitive to limestone and should not be planted in soils containing limestone.

Other rootstock are moderately sensitive to limestone. Ascertain the rootstock tolerance prior to planting.

CEL:JRJ
FRUIT GROWERS LABORATORY, INC.

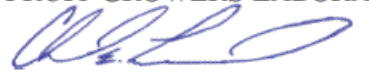

Chad Lessard, Director of Ag. Services 


\section{FRUIT GROWERS LABORATORY, INC.}

\section{Analytical Chemists}

www.fglinc.com

June 27, 2011

Patty Frazer

102 Ravenhill Road

Orinda, CA 94563

Description : Control

Project $\quad$ :Payton Carling/Cal Poly Thesis
Lab ID : SP 1105923-004

Customer ID : 2-23787

Sampled On : May 23, 2011

Sampled By : Payton Carling

Received On : June 13, 2011

Depth :N/A

Meth Irrg. :

WASHINGTON SOIL ANALYSIS

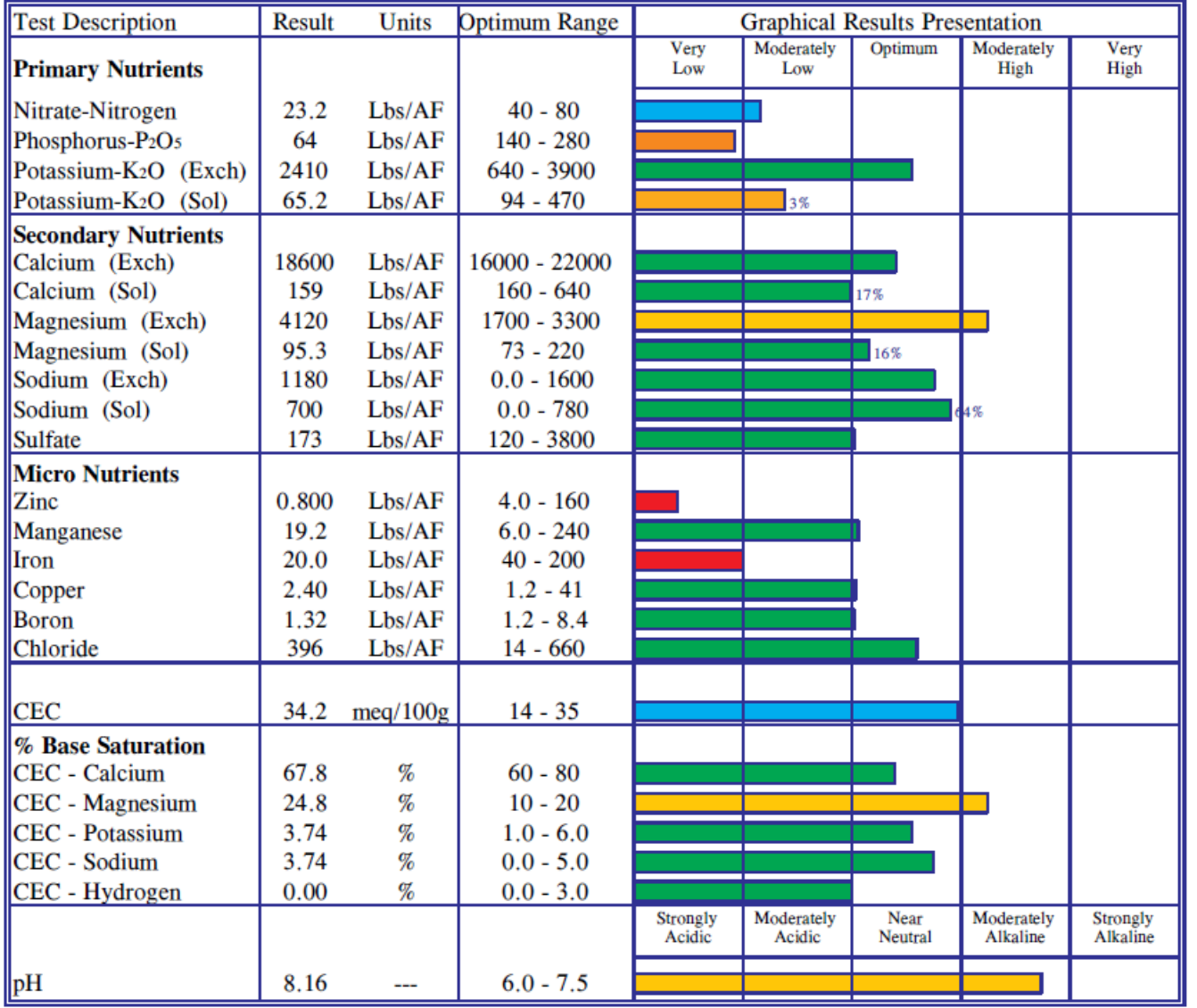

Good $\quad$ Problem Indicates physical conditions and/or phenological and amendment requirements. Note: Color coded bar graphs have been used to provide you with 'AT-A-GLANCE' interpretations.

\begin{tabular}{lllll}
\hline Corporate Offices \& Laboratory & Office \& Laboratory & Office \& Laboratory & Office \& Laboratory & Field Office \\
853 Corporation Street & 2500 Stagecoach Road & 563 East Lindo Avenue & 3442 Empresa Drive, Suite D & Visalia, California \\
Santa Paula, CA 93060 & Stockton, CA 95215 & Chico, CA 95926 & San Luis Obispo, CA 93401 & TEL: (559) 734-9473 \\
TEL: (805) 392-2000 & TEL: (209) 942-0182 & TEL: (530) 343-5818 & TEL: (805) 783-2940 & FAX: (559) 734-8435 \\
FAX: (805) 392-2063 & FAX: (209) $942-0423$ & FAX: (530) 343-3807 & FAX: (805) 392-2063 & Mobile: (559) 737-2399
\end{tabular}


June 27, 2011

Lab ID : : SP 1105923-004

Patty Frazer

Customer ID : 2-23787

Description : Control

WASHINGTON SOIL ANALYSIS

\begin{tabular}{|c|c|c|c|c|c|c|c|c|c|c|}
\hline Test Description & Result & Units & Optimum Range & \multicolumn{7}{|c|}{ Graphical Results Presentation } \\
\hline Others & & \multirow{3}{*}{$\begin{array}{c}\text { mmhos } / \mathrm{cm} \\
\%\end{array}$} & \multirow{3}{*}{$\begin{array}{c}0.0-2.0 \\
0.0-6.0 \\
0.0-0.50 \\
\end{array}$} & \multicolumn{2}{|c|}{\begin{tabular}{l|l} 
Satisfactory & \\
\end{tabular}} & \multicolumn{2}{|c|}{\begin{tabular}{l|l}
$\begin{array}{l}\text { Possible } \\
\text { Problem }\end{array}$ & \\
\end{tabular}} & $\begin{array}{l}\text { Moderate } \\
\text { Problem }\end{array}$ & \multicolumn{2}{|c|}{$\begin{array}{c}\begin{array}{c}\text { Increasing } \\
\text { Problem }\end{array} \\
\end{array}$} \\
\hline $\begin{array}{l}\text { Soil Salinity } \\
\text { SAR } \\
\text { Limestone }\end{array}$ & $\begin{array}{l}1.10 \\
5.4 \\
1.0\end{array}$ & & & & & & & & & \\
\hline & & & & 0 & 1 & 2 & $\frac{1}{3}$ & 4 & 5 & 6 \\
\hline Lime Requirement & 0 & Tons/AF & --- & & & & & & & \\
\hline \multirow[b]{2}{*}{ Moisture } & \multirow[b]{2}{*}{7.2} & \multirow[b]{2}{*}{$\%$} & \multirow[b]{2}{*}{$3.4-24$} & \multicolumn{3}{|c|}{$\begin{array}{c}\text { Moderately } \\
\text { Low }\end{array}$} & Optimum & \multicolumn{2}{|c|}{$\begin{array}{c}\text { Moderately } \\
\text { High }\end{array}$} & $\begin{array}{l}\text { Very } \\
\text { High }\end{array}$ \\
\hline & & & & & & & & & & \\
\hline \multirow[b]{2}{*}{ Saturation } & \multirow[b]{2}{*}{34.2} & \multirow[b]{2}{*}{$\%$} & \multirow[b]{2}{*}{$40-50$} & $\begin{array}{l}\text { Loamy } \\
\text { Sand }\end{array}$ & $\begin{array}{l}\begin{array}{l}\text { Sandy } \\
\text { Loam }\end{array} \\
\text { Lon }\end{array}$ & Loam & $\begin{array}{c}\text { Silt } \\
\text { Loam }\end{array}$ & $\begin{array}{l}\text { Clay } \\
\text { Loam }\end{array}$ & Clay & Organic \\
\hline & & & & & & $\square$ & & & & \\
\hline
\end{tabular}

Good $\quad$ Problem Indicates physical conditions and/or phenological and amendment requirements.

Note: Color coded bar graphs have been used to provide you with 'AT-A-GLANCE' interpretations.

1) The need for soil Nitrate is dependant upon crop phenology (Growth Stage) and crop requirement. A soil Nitrate level of $10-40 \mathrm{ppm}$ is preferred for a short time during critical periods of uptake into the tree. It is highly desirable to have low soil Nitrate $(<5 \mathrm{ppm})$ prior to winter rainfall and cold soil conditions. Use the leaf Nitrogen level to determine primary Nitrogen requirement.

2) Trifoliate \& Citrumelo rootstocks are very sensitive to limestone and should not be planted in soils containing limestone.

Other rootstock are moderately sensitive to limestone. Ascertain the rootstock tolerance prior to planting.

CEL:JRJ
FRUIT GROWERS LABORATORY, INC.

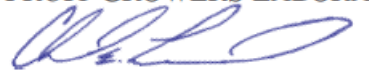

Chad Lessard, Director of Ag. Services 


\section{FRUIT GROWERS LABORATORY, INC.}

June 27, 2011

Patty Frazer

102 Ravenhill Road

Orinda, CA 94563

Description : Hurricane Effected Orchard Project

$$
\begin{array}{ll}
\text { Lab ID } & \text { : SP 1105923-007 } \\
\text { Customer ID } & : \text { 2-23787 } \\
\text { Sampled On } & : \text { May 23, 2011 } \\
\text { Sampled By } & \text { : Payton Carling } \\
\text { Received On } & \text { : June 13, 2011 } \\
\text { Depth } & \text { : N/A } \\
\text { Meth Irrg. } & :
\end{array}
$$

\begin{tabular}{|c|c|c|c|c|c|c|c|c|}
\hline Test Description & Result & Units & Optimum Range & & Graphical & esults Pr & entation & \\
\hline Primary Nutrients & & & & $\begin{array}{l}\text { Very } \\
\text { Low }\end{array}$ & $\begin{array}{l}\text { Moderately } \\
\text { Low }\end{array}$ & Optimum & $\begin{array}{l}\text { Moderately } \\
\text { High }\end{array}$ & $\begin{array}{l}\text { Very } \\
\text { High }\end{array}$ \\
\hline Nitrate-Nitrogen & 32.4 & $\mathrm{Lbs} / \mathrm{AF}$ & $40-80$ & & & & & \\
\hline Phosphorus- $\mathrm{P}_{2} \mathrm{O}_{5}$ & 55 & $\mathrm{Lbs} / \mathrm{AF}$ & $140-280$ & $\longrightarrow$ & & & & \\
\hline Potassium- $\mathrm{K}_{2} \mathrm{O}$ (Exch) & 3670 & $\mathrm{Lbs} / \mathrm{AF}$ & $1000-6300$ & & & & & \\
\hline Potassium- $\mathrm{K}_{2} \mathrm{O}$ (Sol) & 40.5 & $\mathrm{Lbs} / \mathrm{AF}$ & $94-470$ & & 6 & & & \\
\hline Secondary Nutrients & & & & & & & & \\
\hline Calcium (Exch) & 26100 & Lbs/AF & $27000-36000$ & & & & & \\
\hline Calcium (Sol) & 156 & $\mathrm{Lbs} / \mathrm{AF}$ & $160-640$ & & & $1 \%$ & & \\
\hline Magnesium (Exch) & 7870 & $\mathrm{Lbs} / \mathrm{AF}$ & $2700-5400$ & & & & & \\
\hline Magnesium (Sol) & 114 & $\mathrm{Lbs} / \mathrm{AF}$ & $73-220$ & & & $13 \%$ & & \\
\hline Sodium (Exch) & 4880 & $\mathrm{Lbs} / \mathrm{AF}$ & $0.0-2600$ & & & & & \\
\hline Sodium (Sol) & 1280 & $\mathrm{Lbs} / \mathrm{AF}$ & $0.0-810$ & & & & $76 \%$ & \\
\hline Sulfate & 507 & $\mathrm{Lbs} / \mathrm{AF}$ & $120-3800$ & & & & & \\
\hline $\begin{array}{l}\text { Micro Nutrients } \\
\text { Zinc }\end{array}$ & 1.20 & $\mathrm{Lbs} / \mathrm{AF}$ & $4.0-160$ & & & & & \\
\hline Manganese & 18.0 & $\mathrm{Lbs} / \mathrm{AF}$ & $6.0-240$ & & & & & \\
\hline Iron & 39.6 & $\mathrm{Lbs} / \mathrm{AF}$ & $40-200$ & & & & & \\
\hline Copper & 3.60 & $\mathrm{Lbs} / \mathrm{AF}$ & $1.2-41$ & & & & & \\
\hline Boron & 4.24 & $\mathrm{Lbs} / \mathrm{AF}$ & $1.2-8.4$ & & & & & \\
\hline Chloride & 1080 & $\mathrm{Lbs} / \mathrm{AF}$ & $14-660$ & & & & & \\
\hline CEC & 56.0 & meq $/ 100 \mathrm{~g}$ & $14-35$ & & & & & \\
\hline$\%$ Base Saturation & & & & & & & & \\
\hline CEC - Calcium & 58.0 & $\%$ & $60-80$ & & & & & \\
\hline CEC - Magnesium & 28.9 & $\%$ & $10-20$ & & & & & \\
\hline CEC - Potassium & 3.48 & $\%$ & $1.0-6.0$ & & & & & \\
\hline CEC - Sodium & 9.48 & $\%$ & $0.0-5.0$ & & & & & \\
\hline CEC - Hydrogen & 0.00 & $\%$ & $0.0-3.0$ & & & & & \\
\hline \multirow{2}{*}{ 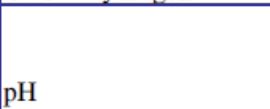 } & \multirow[b]{2}{*}{8.34} & & \multirow[b]{2}{*}{$6.0-7.5$} & $\begin{array}{l}\text { Strongly } \\
\text { Acidic }\end{array}$ & $\begin{array}{l}\text { Moderately } \\
\text { Acidic }\end{array}$ & $\begin{array}{l}\text { Near } \\
\text { Neutral }\end{array}$ & $\begin{array}{l}\text { Moderately } \\
\text { Alkaline }\end{array}$ & $\begin{array}{l}\text { Strongly } \\
\text { Alkaline }\end{array}$ \\
\hline & & -- & & & & & & \\
\hline
\end{tabular}

WASHINGTON SOIL ANALYSIS

Good $\quad$ Problem Indicates physical conditions and/or phenological and amendment requirements. Note: Color coded bar graphs have been used to provide you with 'AT-A-GLANCE' interpretations.

\begin{tabular}{lllll}
\hline Corporate Offices \& Laboratory & Office \& Laboratory & Office \& Laboratory & Office \& Laboratory & Field Office \\
853 Corporation Street & 2500 Stagecoach Road & 563 East Lindo Avenue & 3442 Empresa Drive, Suite D & Visalia, California \\
Santa Paula, CA 93060 & Stockton, CA 95215 & Chico, CA 95926 & San Luis Obispo, CA 93401 & TEL: (559) 734-9473 \\
TEL: (805) 392-2000 & TEL: (209) 942-0182 & TEL: (530) 343-5818 & TEL: (805) 783-2940 & FAX: (559) 734-8435 \\
FAX: (805) 392-2063 & FAX: (209) $942-0423$ & FAX: (530) 343-3807 & FAX: (805) 392-2063 & Mobile: (559) 737-2399
\end{tabular}


June 27, 2011

Lab ID : : SP 1105923-007

Patty Frazer

Customer ID : 2-23787

Description : Hurricane Effected Orchard

WASHINGTON SOIL ANALYSIS

\begin{tabular}{|c|c|c|c|c|c|c|c|c|c|c|}
\hline Test Description & \multirow{5}{*}{\multicolumn{2}{|c|}{\begin{tabular}{cc|} 
Result & Units \\
& \\
& \\
1.87 & $\mathrm{mmhos} / \mathrm{cm}$ \\
9.5 & \\
2.1 & $\%$
\end{tabular}}} & Optimum Range & \multicolumn{7}{|c|}{ Graphical Results Presentation } \\
\hline \multirow{5}{*}{$\begin{array}{l}\text { Others } \\
\text { Soil Salinity } \\
\text { SAR } \\
\text { Limestone }\end{array}$} & & & \multirow{4}{*}{$\begin{array}{c}0.0-2.0 \\
0.0-6.0 \\
0.0-0.50 \\
\end{array}$} & \multicolumn{2}{|c|}{\begin{tabular}{l|l} 
Satisfactory & \\
\end{tabular}} & \multicolumn{2}{|c|}{\begin{tabular}{l|l|} 
Possible & \\
Problem
\end{tabular}} & $\begin{array}{c}\text { Moderate } \\
\text { Problem }\end{array}$ & \multicolumn{2}{|c|}{$\begin{array}{c}\text { Increasing } \\
\text { Problem }\end{array}$} \\
\hline & & & & & & & & & & \\
\hline & & & & & & & & & & \\
\hline & & & & & & $コ$ & & & & \\
\hline & & & & 0 & 1 & 2 & 3 & 4 & 5 & 6 \\
\hline Lime Requirement & 0 & Tons/AF & $\ldots$ & & & & & & & \\
\hline & & & & $\begin{array}{l}\text { Very } \\
\text { Low }\end{array}$ & & $\begin{array}{l}\text { rately } \\
\text { ow }\end{array}$ & Optimum & $\begin{array}{r}\text { Moder } \\
\text { His }\end{array}$ & & $\begin{array}{l}\text { Very } \\
\text { High }\end{array}$ \\
\hline Moisture & 4.2 & $\%$ & $3.5-25$ & & & & & & & \\
\hline & & & & $\begin{array}{l}\text { Loamy } \\
\text { Sand }\end{array}$ & $\begin{array}{l}\text { Sandy } \\
\text { Loam }\end{array}$ & Loam & $\begin{array}{c}\text { Silt } \\
\text { Loam }\end{array}$ & $\begin{array}{c}\text { Clay } \\
\text { Loam }\end{array}$ & Clay & Organic \\
\hline Saturation & 35.2 & $\%$ & $40-50$ & & & $\square$ & & & & \\
\hline
\end{tabular}

Good $\quad$ Problem Indicates physical conditions and/or phenological and amendment requirements.

Note: Color coded bar graphs have been used to provide you with 'AT-A-GLANCE' interpretations.

1) The need for soil Nitrate is dependant upon crop phenology (Growth Stage) and crop requirement. A soil Nitrate level of $10-40 \mathrm{ppm}$ is preferred for a short time during critical periods of uptake into the tree. It is highly desirable to have low soil Nitrate $(<5 \mathrm{ppm})$ prior to winter rainfall and cold soil conditions. Use the leaf Nitrogen level to determine primary Nitrogen requirement.

2) Trifoliate \& Citrumelo rootstocks are very sensitive to limestone and should not be planted in soils containing limestone.

Other rootstock are moderately sensitive to limestone. Ascertain the rootstock tolerance prior to planting.

CEL:JRJ
FRUIT GROWERS LABORATORY, INC.

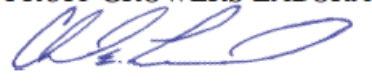

Chad Lessard, Director of Ag. Services 


\section{FRUIT GROWERS LABORATORY, INC.}

\section{Analytical Chemists}

www.fglinc.com

July 12, 2011

Patty Frazer

102 Ravenhill Road

Orinda, CA 94563

Description : C + VTF

Project $\quad$ :Payton Carling/Cal Poly Thesis
Lab ID : : SP 1105923-001

Customer ID : 2-23787

Sampled On : May 23, 2011

Sampled By : Payton Carling

Received On : June 13, 2011

Depth : N/A

Meth Irrg. :

WASHINGTON SOIL ANALYSIS

\begin{tabular}{|c|c|c|c|c|c|c|c|c|}
\hline Test Description & Result & Units & Optimum Range & & Graphical & esults $\operatorname{Pr}$ & entation & \\
\hline Primary Nutrients & & & & $\begin{array}{l}\text { Very } \\
\text { Low }\end{array}$ & $\begin{array}{l}\text { Moderately } \\
\text { Low }\end{array}$ & Optimum & $\begin{array}{c}\text { Moderately } \\
\text { High }\end{array}$ & $\begin{array}{l}\text { Very } \\
\text { High }\end{array}$ \\
\hline Nitrate-Nitrogen & 96.4 & $\mathrm{Lbs} / \mathrm{AF}$ & $40-80$ & & & & $\square$ & \\
\hline Phosphorus- $\mathrm{P}_{2} \mathrm{O}_{5}$ & 651 & $\mathrm{Lbs} / \mathrm{AF}$ & $140-280$ & & & & & \\
\hline Potassium- $\mathrm{K}_{2} \mathrm{O}$ (Exch) & 4550 & $\mathrm{Lbs} / \mathrm{AF}$ & $680-4100$ & & & & & \\
\hline Potassium- $\mathrm{K}_{2} \mathrm{O}$ (Sol) & 218 & $\mathrm{Lbs} / \mathrm{AF}$ & $94-470$ & & & $6 \%$ & & \\
\hline Secondary Nutrients & & & & & & & & \\
\hline Calcium (Exch) & 18800 & $\mathrm{Lbs} / \mathrm{AF}$ & $18000-23000$ & & & & & \\
\hline Calcium (Sol) & 374 & $\mathrm{Lbs} / \mathrm{AF}$ & $160-640$ & & & I22\% & & \\
\hline Magnesium (Exch) & 4420 & $\mathrm{Lbs} / \mathrm{AF}$ & $1800-3500$ & & & & $\square$ & \\
\hline Magnesium (Sol) & 226 & $\mathrm{Lbs} / \mathrm{AF}$ & $73-220$ & & & & $22 \%$ & \\
\hline Sodium (Exch) & 1280 & $\mathrm{Lbs} / \mathrm{AF}$ & $0.0-1700$ & & & & & \\
\hline Sodium (Sol) & 956 & $\mathrm{Lbs} / \mathrm{AF}$ & $0.0-1200$ & & & & $\%$ & \\
\hline Sulfate & 359 & $\mathrm{Lbs} / \mathrm{AF}$ & $120-3800$ & & & & & \\
\hline Micro Nutrients & & & & & & & & \\
\hline Zinc & 5.60 & $\mathrm{Lbs} / \mathrm{AF}$ & $4.0-160$ & & & & & \\
\hline Manganese & 28.4 & $\mathrm{Lbs} / \mathrm{AF}$ & $6.0-240$ & & & & & \\
\hline Iron & 21.6 & $\mathrm{Lbs} / \mathrm{AF}$ & $40-200$ & & & & & \\
\hline Copper & 2.40 & Lbs/AF & $1.2-41$ & & & & & \\
\hline Boron & 3.00 & $\mathrm{Lbs} / \mathrm{AF}$ & $1.2-8.4$ & & & & & \\
\hline Chloride & 478 & $\mathrm{Lbs} / \mathrm{AF}$ & $14-660$ & & & & & \\
\hline $\mathrm{CEC}$ & 36.3 & $\mathrm{meq} / 100 \mathrm{~g}$ & $14-35$ & & & & & \\
\hline$\%$ Base Saturation & & & & & & & & \\
\hline CEC - Calcium & 64.5 & $\%$ & $60-80$ & & & & & \\
\hline CEC - Magnesium & 25.1 & $\%$ & $10-20$ & & & & $\square$ & \\
\hline CEC - Potassium & 6.67 & $\%$ & $1.0-6.0$ & & & & & \\
\hline CEC - Sodium & 3.83 & $\%$ & $0.0-5.0$ & & & & & \\
\hline CEC - Hydrogen & 0.00 & $\%$ & $0.0-3.0$ & & & & & \\
\hline \multirow{2}{*}{ 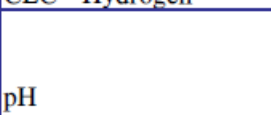 } & & & \multirow[b]{2}{*}{$6.0-7.5$} & $\begin{array}{l}\text { Strongly } \\
\text { Acidic }\end{array}$ & $\begin{array}{l}\text { Moderately } \\
\text { Acidic }\end{array}$ & $\begin{array}{c}\text { Near } \\
\text { Neutral }\end{array}$ & $\begin{array}{l}\text { Moderately } \\
\text { Alkaline }\end{array}$ & $\begin{array}{l}\text { Strongly } \\
\text { Alkaline }\end{array}$ \\
\hline & 7.92 & --- & & & & & & \\
\hline
\end{tabular}

Good $\quad$ Problem Indicates physical conditions and/or phenological and amendment requirements. Note: Color coded bar graphs have been used to provide you with 'AT-A-GLANCE' interpretations.

\begin{tabular}{lllll}
\hline Corporate Offices \& Laboratory & Office \& Laboratory & Office \& Laboratory & Office \& Laboratory & Field Office \\
853 Corporation Street & 2500 Stagecoach Road & 563 East Lindo Avenue & 3442 Empresa Drive, Suite D & Visalia, California \\
Santa Paula, CA 93060 & Stockton, CA 95215 & Chico, CA 95926 & San Luis Obispo, CA 93401 & TEL: (559) 734-9473 \\
TEL: (805) 392-2000 & TEL: (209) 942-0182 & TEL: (530) 343-5818 & TEL: (805) 783-2940 & FAX: (559) 734-8435 \\
FAX: (805) 392-2063 & FAX: (209) $942-0423$ & FAX: (530) 343-3807 & FAX: (805) 392-2063 & Mobile: (559) 737-2399
\end{tabular}


July 12,2011

Lab ID : : SP 1105923-001

Patty Frazer

Customer ID : 2-23787

Description : C + VTF

WASHINGTON SOIL ANALYSIS

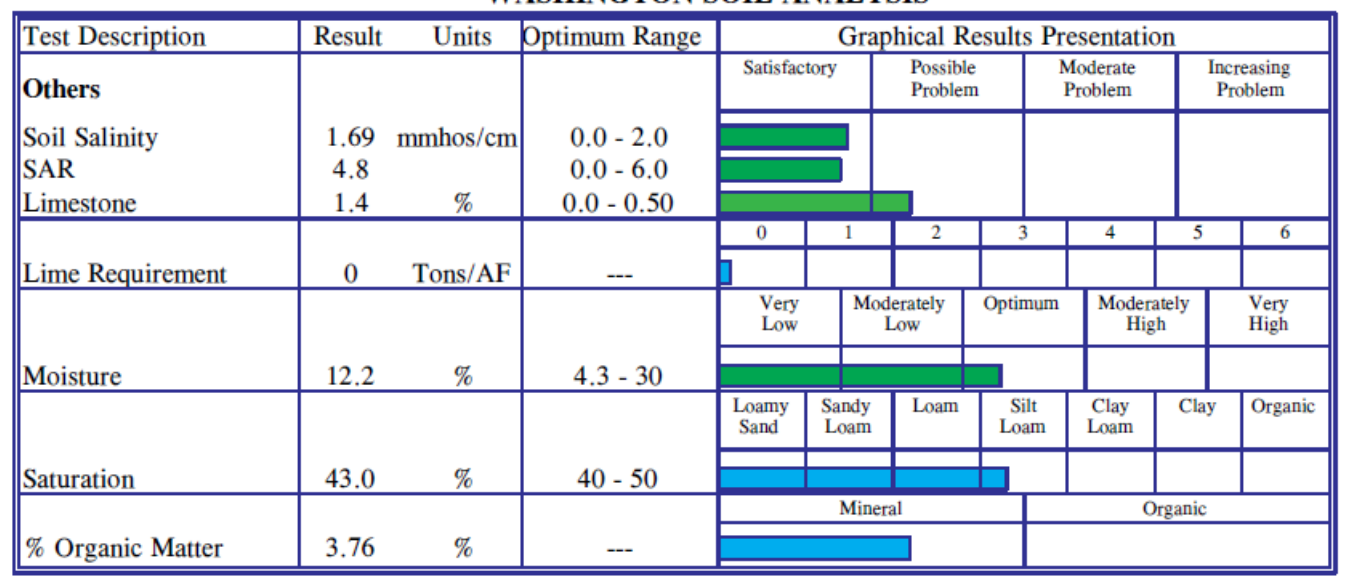

Good $\quad$ Problem Indicates physical conditions and/or phenological and amendment requirements. Note: Color coded bar graphs have been used to provide you with 'AT-A-GLANCE' interpretations.

1) The need for soil Nitrate is dependant upon crop phenology (Growth Stage) and crop requirement. A soil Nitrate level of $10-40 \mathrm{ppm}$ is preferred for a short time during critical periods of uptake into the tree. It is highly desirable to have low soil Nitrate $(<5 \mathrm{ppm})$ prior to winter rainfall and cold soil conditions. Use the leaf Nitrogen level to determine primary Nitrogen requirement.

2) Trifoliate \& Citrumelo rootstocks are very sensitive to limestone and should not be planted in soils containing limestone. Other rootstock are moderately sensitive to limestone. Ascertain the rootstock tolerance prior to planting.

FRUIT GROWERS LABORATORY, INC.

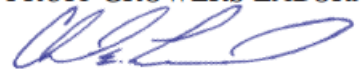

Chad Lessard, Director of Ag. Services 


\section{FRUIT GROWERS LABORATORY, INC.}

Analytical Chemists

July 12, 2011

Patty Frazer

102 Ravenhill Road

Orinda, CA 94563

Description :GMCC + VTF

Project $\quad$ :Payton Carling/Cal Poly Thesis
Lab ID : SP 1105923-002

Customer ID : 2-23787

Sampled On : May 23, 2011

Sampled By : Payton Carling

Received On : June 13, 2011

Depth : N/A

Meth Irrg. :

WASHINGTON SOIL ANALYSIS

\begin{tabular}{|c|c|c|c|c|c|c|c|c|}
\hline Test Description & Result & Units & Optimum Range & & Graphical & esults $\operatorname{Pr}$ & entation & \\
\hline Primary Nutrients & & & & $\begin{array}{l}\text { Very } \\
\text { Low }\end{array}$ & $\begin{array}{l}\text { Moderately } \\
\text { Low }\end{array}$ & Optimum & $\begin{array}{l}\text { Moderately } \\
\text { High }\end{array}$ & $\begin{array}{l}\text { Very } \\
\text { High }\end{array}$ \\
\hline Nitrate-Nitrogen & 41.6 & $\mathrm{Lbs} / \mathrm{AF}$ & $40-80$ & & & & & \\
\hline Phosphorus- $\mathrm{P}_{2} \mathrm{O}_{5}$ & 64 & $\mathrm{Lbs} / \mathrm{AF}$ & $140-280$ & & & & & \\
\hline Potassium- $\mathrm{K}_{2} \mathrm{O}$ (Exch) & 2600 & $\mathrm{Lbs} / \mathrm{AF}$ & $600-3600$ & & & & & \\
\hline Potassium- $\mathrm{K}_{2} \mathrm{O}$ (Sol) & 75.4 & $\mathrm{Lbs} / \mathrm{AF}$ & $94-470$ & & ]$_{3 \%}$ & & & \\
\hline Secondary Nutrients & & & & & & & & \\
\hline Calcium (Exch) & 17000 & $\mathrm{Lbs} / \mathrm{AF}$ & $15000-20000$ & & & & & \\
\hline Calcium (Sol) & 147 & $\mathrm{Lbs} / \mathrm{AF}$ & $160-640$ & & & & & \\
\hline Magnesium (Exch) & 3800 & $\mathrm{Lbs} / \mathrm{AF}$ & $1500-3100$ & & & & $\square$ & \\
\hline Magnesium (Sol) & 89.9 & $\mathrm{Lbs} / \mathrm{AF}$ & $73-220$ & & & $16 \%$ & & \\
\hline Sodium (Exch) & 1120 & $\mathrm{Lbs} / \mathrm{AF}$ & $0.0-1400$ & & & & & \\
\hline Sodium (Sol) & 693 & $\mathrm{Lbs} / \mathrm{AF}$ & $0.0-740$ & & & & $5 \%$ & \\
\hline Sulfate & 174 & $\mathrm{Lbs} / \mathrm{AF}$ & $120-3800$ & & & & & \\
\hline $\begin{array}{l}\text { Micro Nutrients } \\
\text { Zinc }\end{array}$ & 1.20 & $\mathrm{Lbs} / \mathrm{AF}$ & $4.0-160$ & & & & & \\
\hline Manganese & 17.2 & $\mathrm{Lbs} / \mathrm{AF}$ & $6.0-240$ & & & & & \\
\hline Iron & 16.4 & $\mathrm{Lbs} / \mathrm{AF}$ & $40-200$ & & & & & \\
\hline Copper & 2.40 & $\mathrm{Lbs} / \mathrm{AF}$ & $1.2-41$ & & & & & \\
\hline Boron & 1.48 & Lbs/AF & $1.2-8.4$ & & & & & \\
\hline Chloride & 485 & $\mathrm{Lbs} / \mathrm{AF}$ & $14-660$ & & & & & \\
\hline CEC & 31.6 & $\mathrm{meq} / 100 \mathrm{~g}$ & $14-35$ & & & & & \\
\hline$\%$ Base Saturation & & & & & & & & \\
\hline CEC - Calcium & 67.1 & $\%$ & $60-80$ & & & & & \\
\hline CEC - Magnesium & 24.7 & $\%$ & $10-20$ & & & & & \\
\hline CEC - Potassium & 4.37 & $\%$ & $1.0-6.0$ & & & & & \\
\hline CEC - Sodium & 3.86 & $\%$ & $0.0-5.0$ & & & & & \\
\hline CEC - Hydrogen & 0.00 & $\%$ & $0.0-3.0$ & & & & & \\
\hline \multirow[t]{2}{*}{ 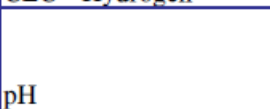 } & \multirow[b]{2}{*}{8.10} & & \multirow[b]{2}{*}{$6.0-7.5$} & $\begin{array}{l}\text { Strongly } \\
\text { Acidic }\end{array}$ & $\begin{array}{l}\text { Moderately } \\
\text { Acidic }\end{array}$ & $\begin{array}{l}\text { Near } \\
\text { Neutral }\end{array}$ & $\begin{array}{l}\text { Moderately } \\
\text { Alkaline }\end{array}$ & $\begin{array}{l}\text { Strongly } \\
\text { Alkaline }\end{array}$ \\
\hline & & -- & & & & & & \\
\hline
\end{tabular}

Good $\quad$ Problem Indicates physical conditions and/or phenological and amendment requirements.

Note: Color coded bar graphs have been used to provide you with 'AT-A-GLANCE' interpretations.

\begin{tabular}{lllll}
\hline Corporate Offices \& Laboratory & Office \& Laboratory & Office \& Laboratory & Office \& Laboratory & Field Office \\
853 Corporation Street & 2500 Stagecoach Road & 563 East Lindo Avenue & 3442 Empresa Drive, Suite D & Visalia, California \\
Santa Paula, CA 93060 & Stockton, CA 95215 & Chico, CA 95926 & San Luis Obispo, CA 93401 & TEL: (559) 734-9473 \\
TEL: (805) 392-2000 & TEL: (209) 942-0182 & TEL: (530) 343-5818 & TEL: (805) 783-2940 & FAX: (559) 734-8435 \\
FAX: (805) 392-2063 & FAX: (209) $942-0423$ & FAX: (530) 343-3807 & FAX: (805) 392-2063 & Mobile: (559) 737-2399
\end{tabular}


July 12,2011

Lab ID : SP 1105923-002

Patty Frazer

Customer ID : 2-23787

Description : GMCC + VTF

WASHINGTON SOIL ANALYSIS

\begin{tabular}{|c|c|c|c|c|c|c|c|c|c|c|}
\hline Test Description & Result & Units & Optimum Range & \multicolumn{7}{|c|}{ Graphical Results Presentation } \\
\hline \multirow{2}{*}{$\begin{array}{l}\text { Others } \\
\text { Soil Salinity } \\
\text { SAR } \\
\text { Limestone } \\
\end{array}$} & \multirow[b]{2}{*}{$\begin{array}{r}1.12 \\
5.6 \\
0.9 \\
\end{array}$} & \multirow[b]{2}{*}{$\begin{array}{c}\mathrm{mmhos} / \mathrm{cm} \\
\% \\
\end{array}$} & \multirow[b]{2}{*}{$\begin{array}{c}0.0-2.0 \\
0.0-6.0 \\
0.0-0.50 \\
\end{array}$} & \multicolumn{2}{|c|}{\begin{tabular}{l|l} 
Satisfactory & \\
\end{tabular}} & \multicolumn{2}{|c|}{\begin{tabular}{l|l}
$\begin{array}{l}\text { Possible } \\
\text { Problem }\end{array}$ & \\
\end{tabular}} & $\begin{array}{l}\text { Moderate } \\
\text { Problem }\end{array}$ & \multicolumn{2}{|c|}{$\begin{array}{c}\text { Increasing } \\
\text { Problem }\end{array}$} \\
\hline & & & & & & & & & & \\
\hline \multirow[b]{2}{*}{ Lime Requirement } & & & \multirow[b]{2}{*}{$\ldots$} & 0 & 1 & 2 & 3 & 4 & 5 & 6 \\
\hline & 0 & Tons/AF & & & & & & & & \\
\hline \multirow[b]{2}{*}{ Moisture } & \multirow[b]{2}{*}{7.4} & \multirow[t]{2}{*}{ 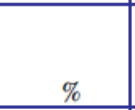 } & \multirow[b]{2}{*}{$3.1-22$} & \multicolumn{3}{|c|}{$\begin{array}{c}\text { Moderately } \\
\text { Low }\end{array}$} & Optimum & \multicolumn{2}{|c|}{$\begin{array}{c}\text { Moderately } \\
\text { High }\end{array}$} & $\begin{array}{l}\text { Very } \\
\text { High }\end{array}$ \\
\hline & & & & & & & & & & \\
\hline \multirow[b]{2}{*}{ Saturation } & & & \multirow[b]{2}{*}{$40-50$} & $\begin{array}{l}\text { Loamy } \\
\text { Sand }\end{array}$ & $\begin{array}{l}\text { Sandy } \\
\text { Loam }\end{array}$ & Loam & $\begin{array}{c}\begin{array}{c}\text { Silt } \\
\text { Loam }\end{array} \\
\end{array}$ & $\begin{array}{l}\text { Clay } \\
\text { Loam }\end{array}$ & Clay & Organic \\
\hline & 30.7 & $\%$ & & & & & & & & \\
\hline \multirow[b]{2}{*}{$\%$ Organic Matter } & & & & \multirow{2}{*}{\multicolumn{3}{|c|}{ Mineral }} & \multirow{2}{*}{\multicolumn{3}{|c|}{ Organic }} & \\
\hline & 1.23 & $\%$ & -- & & & & & & & \\
\hline
\end{tabular}

Good $\quad$ Problem $\quad$ Indicates physical conditions and/or phenological and amendment requirements. Note: Color coded bar graphs have been used to provide you with 'AT-A-GLANCE' interpretations.

1) The need for soil Nitrate is dependant upon crop phenology (Growth Stage) and crop requirement. A soil Nitrate level of $10-40 \mathrm{ppm}$ is preferred for a short time during critical periods of uptake into the tree. It is highly desirable to have low soil Nitrate $(<5 \mathrm{ppm})$ prior to winter rainfall and cold soil conditions. Use the leaf Nitrogen level to determine primary Nitrogen requirement.

2) Trifoliate \& Citrumelo rootstocks are very sensitive to limestone and should not be planted in soils containing limestone. Other rootstock are moderately sensitive to limestone. Ascertain the rootstock tolerance prior to planting.

FRUIT GROWERS LABORATORY, INC.

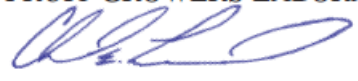

Chad Lessard, Director of Ag. Services 


\section{FRUIT GROWERS LABORATORY, INC.}

\section{Analytical Chemists}

www.fglinc.com

July 12, 2011

Patty Frazer

102 Ravenhill Road

Orinda, CA 94563

Description : VTF

Project :Payton Carling/Cal Poly Thesis
Lab ID : SP 1105923-003

Customer ID : 2-23787

Sampled On : May 23, 2011

Sampled By : Payton Carling

Received On : June 13, 2011

Depth : N/A

Meth Irrg. :

WASHINGTON SOIL ANALYSIS

\begin{tabular}{|c|c|c|c|c|c|c|c|c|}
\hline Test Description & Result & Units & Optimum Range & \multicolumn{5}{|c|}{ Graphical Results Presentation } \\
\hline Primary Nutrients & & & & $\begin{array}{l}\text { Very } \\
\text { Low }\end{array}$ & $\begin{array}{c}\text { Moderately } \\
\text { Low }\end{array}$ & Optimum & $\begin{array}{c}\text { Moderately } \\
\text { High }\end{array}$ & $\begin{array}{l}\text { Very } \\
\text { High }\end{array}$ \\
\hline $\begin{array}{l}\text { Nitrate-Nitrogen } \\
\text { Phosphorus- } \mathrm{P}_{2} \mathrm{O}_{5} \\
\text { Potassium- } \mathrm{K}_{2} \mathrm{O} \text { (Exch) } \\
\text { Potassium- } \mathrm{K}_{2} \mathrm{O} \text { (Sol) }\end{array}$ & $\begin{array}{c}19.6 \\
55 \\
2300 \\
66.7 \\
\end{array}$ & $\begin{array}{l}\mathrm{Lbs} / \mathrm{AF} \\
\mathrm{Lbs} / \mathrm{AF} \\
\mathrm{Lbs} / \mathrm{AF} \\
\mathrm{Lbs} / \mathrm{AF}\end{array}$ & $\begin{array}{c}40-80 \\
140-280 \\
640-3800 \\
94-470 \\
\end{array}$ & 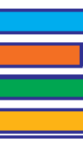 & $\beth_{3 \%}$ & & & \\
\hline $\begin{array}{l}\text { Secondary Nutrients } \\
\text { Calcium (Exch) } \\
\text { Calcium (Sol) } \\
\text { Magnesium (Exch) } \\
\text { Magnesium (Sol) } \\
\text { Sodium (Exch) } \\
\text { Sodium (Sol) } \\
\text { Sulfate } \\
\end{array}$ & $\begin{array}{c}18500 \\
169 \\
4090 \\
105 \\
1160 \\
748 \\
207 \\
\end{array}$ & $\begin{array}{l}\mathrm{Lbs} / \mathrm{AF} \\
\mathrm{Lbs} / \mathrm{AF} \\
\mathrm{Lbs} / \mathrm{AF} \\
\mathrm{Lbs} / \mathrm{AF} \\
\mathrm{Lbs} / \mathrm{AF} \\
\mathrm{Lbs} / \mathrm{AF} \\
\mathrm{Lbs} / \mathrm{AF}\end{array}$ & $\begin{array}{c}16000-22000 \\
160-640 \\
1600-3300 \\
73-220 \\
0.0-1600 \\
0.0-800 \\
120-3800 \\
\end{array}$ & & & $\overline{17 \%}$ & $\square$ & \\
\hline $\begin{array}{l}\text { Micro Nutrients } \\
\text { Zinc } \\
\text { Manganese } \\
\text { Iron } \\
\text { Copper } \\
\text { Boron } \\
\text { Chloride } \\
\end{array}$ & $\begin{array}{c}0.800 \\
18.8 \\
18.8 \\
2.00 \\
1.32 \\
525 \\
\end{array}$ & $\begin{array}{l}\mathrm{Lbs} / \mathrm{AF} \\
\mathrm{Lbs} / \mathrm{AF} \\
\mathrm{Lbs} / \mathrm{AF} \\
\mathrm{Lbs} / \mathrm{AF} \\
\mathrm{Lbs} / \mathrm{AF} \\
\mathrm{Lbs} / \mathrm{AF}\end{array}$ & $\begin{array}{l}4.0-160 \\
6.0-240 \\
40-200 \\
1.2-41 \\
1.2-8.4 \\
14-660 \\
\end{array}$ & & & & & \\
\hline CEC & 34.0 & meq $/ 100 \mathrm{~g}$ & $14-35$ & & & & & \\
\hline $\begin{array}{l}\text { \% Base Saturation } \\
\text { CEC - Calcium } \\
\text { CEC - Magnesium } \\
\text { CEC - Potassium } \\
\text { CEC - Sodium } \\
\text { CEC - Hydrogen }\end{array}$ & $\begin{array}{l}67.9 \\
24.8 \\
3.59 \\
3.71 \\
0.00\end{array}$ & $\begin{array}{l}\% \\
\% \\
\% \\
\% \\
\%\end{array}$ & $\begin{array}{c}60-80 \\
10-20 \\
1.0-6.0 \\
0.0-5.0 \\
0.0-3.0\end{array}$ & & & & & \\
\hline & & & & $\begin{array}{c}\text { Strongly } \\
\text { Acidic }\end{array}$ & $\begin{array}{c}\text { Moderately } \\
\text { Acidic }\end{array}$ & $\begin{array}{c}\text { Near } \\
\text { Neutral }\end{array}$ & $\begin{array}{c}\text { Moderately } \\
\text { Alkaline }\end{array}$ & $\begin{array}{l}\text { Strongly } \\
\text { Alkaline }\end{array}$ \\
\hline $\mathrm{pH}$ & 8.18 & -- & $6.0-7.5$ & & & & & \\
\hline
\end{tabular}

Good $\quad$ Problem Indicates physical conditions and/or phenological and amendment requirements. Note: Color coded bar graphs have been used to provide you with 'AT-A-GLANCE' interpretations.

\begin{tabular}{lllll}
\hline Corporate Offices \& Laboratory & Office \& Laboratory & Office \& Laboratory & Office \& Laboratory & Field Office \\
853 Corporation Street & 2500 Stagecoach Road & 563 East Lindo Avenue & 3442 Empresa Drive, Suite D & Visalia, California \\
Santa Paula, CA 93060 & Stockton, CA 95215 & Chico, CA 95926 & San Luis Obispo, CA 93401 & TEL: (559) 734-9473 \\
TEL: (805) 392-2000 & TEL: (209) 942-0182 & TEL: (530) 343-5818 & TEL: (805) 783-2940 & FAX: (559) 734-8435 \\
FAX: (805) 392-2063 & FAX: (209) 942-0423 & FAX: (530) 343-3807 & FAX: (805) 392-2063 & Mobile: (559) 737-2399
\end{tabular}


July 12,2011

Lab ID : SP 1105923-003

Patty Frazer

Customer ID : 2-23787

Description : VTF

WASHINGTON SOIL ANALYSIS

\begin{tabular}{|c|c|c|c|c|c|c|c|c|c|c|}
\hline Test Description & Result & Units & Optimum Range & \multicolumn{7}{|c|}{ Graphical Results Presentation } \\
\hline Others & \multirow[b]{2}{*}{$\begin{array}{r}1.22 \\
5.6 \\
1.4 \\
\end{array}$} & \multirow{3}{*}{$\begin{array}{c}\text { mmhos/cm } \\
\% \\
\end{array}$} & \multirow{3}{*}{$\begin{array}{c}0.0-2.0 \\
0.0-6.0 \\
0.0-0.50 \\
\end{array}$} & \multicolumn{2}{|c|}{\begin{tabular}{l|l} 
Satisfactory & \\
\end{tabular}} & \multicolumn{2}{|c|}{\begin{tabular}{l|l}
$\begin{array}{l}\text { Possible } \\
\text { Problem }\end{array}$ & \\
\end{tabular}} & $\begin{array}{l}\text { Moderate } \\
\text { Problem }\end{array}$ & \multicolumn{2}{|c|}{ 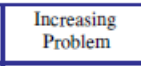 } \\
\hline $\begin{array}{l}\text { Soil Salinity } \\
\text { SAR } \\
\text { Limestone }\end{array}$ & & & & & & & & & & \\
\hline & & & & 0 & 1 & 2 & 3 & 4 & 5 & 6 \\
\hline Lime Requirement & 0 & Tons/AF & --- & & & & & & & \\
\hline \multirow[b]{2}{*}{ Moisture } & \multirow[b]{2}{*}{6.5} & \multirow[b]{2}{*}{$\%$} & \multirow[b]{2}{*}{$3.3-23$} & \multicolumn{3}{|c|}{\begin{tabular}{|c|}
$\begin{array}{c}\text { Moderately } \\
\text { Low }\end{array}$ \\
\end{tabular}} & Optimum & \multirow{2}{*}{\multicolumn{2}{|c|}{\begin{tabular}{|c|}
$\begin{array}{c}\text { Moderately } \\
\text { High }\end{array}$ \\
\end{tabular}}} & $\begin{array}{l}\text { Very } \\
\text { High }\end{array}$ \\
\hline & & & & & & & 1 & & & \\
\hline \multirow[b]{2}{*}{ Saturation } & & & \multirow[b]{2}{*}{$40-50$} & $\begin{array}{l}\text { Loamy } \\
\text { Sand }\end{array}$ & $\begin{array}{l}\begin{array}{l}\text { Sandy } \\
\text { Loam }\end{array} \\
\text { L }\end{array}$ & Loam & $\begin{array}{c}\text { Silt } \\
\text { Loam }\end{array}$ & $\begin{array}{l}\text { Clay } \\
\text { Loam }\end{array}$ & Clay & Organic \\
\hline & 33.1 & $\%$ & & & & $\square$ & & \multirow{2}{*}{\multicolumn{3}{|c|}{ Organic }} \\
\hline & & & & \multicolumn{4}{|c|}{ Mineral } & & & \\
\hline \% Organic Matter & 1.39 & $\%$ & -- & $\square$ & & & & & & \\
\hline
\end{tabular}

Good Problem Indicates physical conditions and/or phenological and amendment requirements.

Note: Color coded bar graphs have been used to provide you with 'AT-A-GLANCE' interpretations.

1) The need for soil Nitrate is dependant upon crop phenology (Growth Stage) and crop requirement. A soil Nitrate level of $10-40 \mathrm{ppm}$ is preferred for a short time during critical periods of uptake into the tree. It is highly desirable to have low soil Nitrate $(<5 \mathrm{ppm})$ prior to winter rainfall and cold soil conditions. Use the leaf Nitrogen level to determine primary Nitrogen requirement.

2) Trifoliate \& Citrumelo rootstocks are very sensitive to limestone and should not be planted in soils containing limestone. Other rootstock are moderately sensitive to limestone. Ascertain the rootstock tolerance prior to planting.

FRUIT GROWERS LABORATORY, INC.

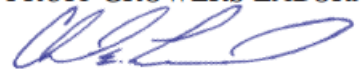

Chad Lessard, Director of Ag. Services 


\section{FRUIT GROWERS LABORATORY, INC.}

\section{Analytical Chemists}

www.fglinc.com

July 12, 2011

Patty Frazer

102 Ravenhill Road

Orinda, CA 94563

Description : Control

Project $\quad$ :Payton Carling/Cal Poly Thesis
Lab ID : SP 1105923-004

Customer ID : 2-23787

Sampled On : May 23, 2011

Sampled By : Payton Carling

Received On : June 13, 2011

Depth : N/A

Meth Irrg. :

WASHINGTON SOIL ANALYSIS

\begin{tabular}{|c|c|c|c|c|c|c|c|c|}
\hline Test Description & Result & Units & Optimum Range & \multicolumn{5}{|c|}{ Graphical Results Presentation } \\
\hline Primary Nutrients & & & & $\begin{array}{l}\text { Very } \\
\text { Low }\end{array}$ & $\begin{array}{c}\text { Moderately } \\
\text { Low }\end{array}$ & Optimum & $\begin{array}{c}\text { Moderately } \\
\text { High }\end{array}$ & $\begin{array}{l}\text { Very } \\
\text { High }\end{array}$ \\
\hline Nitrate-Nitrogen & 23.2 & $\mathrm{Lbs} / \mathrm{AF}$ & $40-80$ & & $\neg$ & & & \\
\hline Phosphorus- $\mathrm{P}_{2} \mathrm{O}_{5}$ & 64 & $\mathrm{Lbs} / \mathrm{AF}$ & $140-280$ & & & & & \\
\hline Potassium- $\mathrm{K}_{2} \mathrm{O}$ (Exch) & 2410 & $\mathrm{Lbs} / \mathrm{AF}$ & $640-3900$ & & & & & \\
\hline Potassium- $\mathrm{K}_{2} \mathrm{O}$ (Sol) & 65.2 & $\mathrm{Lbs} / \mathrm{AF}$ & $94-470$ & & ]$_{3 \%}$ & & & \\
\hline Secondary Nutrients & & & & & & & & \\
\hline Calcium (Exch) & 18600 & $\mathrm{Lbs} / \mathrm{AF}$ & $16000-22000$ & & & & & \\
\hline Calcium (Sol) & 159 & $\mathrm{Lbs} / \mathrm{AF}$ & $160-640$ & & & $17 \%$ & & \\
\hline Magnesium (Exch) & 4120 & $\mathrm{Lbs} / \mathrm{AF}$ & $1700-3300$ & & & & $\square$ & \\
\hline Magnesium (Sol) & 95.3 & $\mathrm{Lbs} / \mathrm{AF}$ & $73-220$ & & & $16 \%$ & & \\
\hline Sodium (Exch) & 1180 & $\mathrm{Lbs} / \mathrm{AF}$ & $0.0-1600$ & & & & & \\
\hline Sodium (Sol) & 700 & $\mathrm{Lbs} / \mathrm{AF}$ & $0.0-780$ & & & & $4 \%$ & \\
\hline Sulfate & 173 & $\mathrm{Lbs} / \mathrm{AF}$ & $120-3800$ & & & & & \\
\hline Micro Nutrients & & & & & & & & \\
\hline Zinc & 0.800 & $\mathrm{Lbs} / \mathrm{AF}$ & $4.0-160$ & & & & & \\
\hline Manganese & 19.2 & $\mathrm{Lbs} / \mathrm{AF}$ & $6.0-240$ & & & & & \\
\hline Iron & 20.0 & Lbs/AF & $40-200$ & & & & & \\
\hline Copper & 2.40 & Lbs/AF & $1.2-41$ & & & & & \\
\hline Boron & 1.32 & $\mathrm{Lbs} / \mathrm{AF}$ & $1.2-8.4$ & & & & & \\
\hline Chloride & 396 & $\mathrm{Lbs} / \mathrm{AF}$ & $14-660$ & & & & & \\
\hline CEC & 34.2 & meq $/ 100 \mathrm{~g}$ & $14-35$ & & & & & \\
\hline$\%$ Base Saturation & & & & & & & & \\
\hline CEC - Calcium & 67.8 & $\%$ & $60-80$ & & & & & \\
\hline CEC - Magnesium & 24.8 & $\%$ & $10-20$ & & & & $\square$ & \\
\hline CEC - Potassium & 3.74 & $\%$ & $1.0-6.0$ & & & & & \\
\hline CEC - Sodium & 3.74 & $\%$ & $0.0-5.0$ & & & & & \\
\hline CEC - Hydrogen & 0.00 & $\%$ & $0.0-3.0$ & & & & & \\
\hline & & & & $\begin{array}{r}\text { Strongly } \\
\text { Acidic }\end{array}$ & $\begin{array}{c}\text { Moderately } \\
\text { Acidic }\end{array}$ & $\begin{array}{c}\text { Near } \\
\text { Neutral }\end{array}$ & $\begin{array}{c}\text { Moderately } \\
\text { Alkaline }\end{array}$ & $\begin{array}{l}\text { Strongly } \\
\text { Alkaline }\end{array}$ \\
\hline $\mathrm{pH}$ & 8.16 & - & $6.0-7.5$ & & & & & \\
\hline
\end{tabular}

Good $\quad$ Problem Indicates physical conditions and/or phenological and amendment requirements. Note: Color coded bar graphs have been used to provide you with 'AT-A-GLANCE' interpretations.

\begin{tabular}{lllll}
\hline Corporate Offices \& Laboratory & Office \& Laboratory & Office \& Laboratory & Office \& Laboratory & Field Office \\
853 Corporation Street & 2500 Stagecoach Road & 563 East Lindo Avenue & 3442 Empresa Drive, Suite D & Visalia, California \\
Santa Paula, CA 93060 & Stockton, CA 95215 & Chico, CA 95926 & San Luis Obispo, CA 93401 & TEL: (559) 734-9473 \\
TEL: (805) 392-2000 & TEL: (209) 942-0182 & TEL: (530) 343-5818 & TEL: (805) 783-2940 & FAX: (559) 734-8435 \\
FAX: (805) 392-2063 & FAX: (209) $942-0423$ & FAX: (530) 343-3807 & FAX: (805) 392-2063 & Mobile: (559) 737-2399
\end{tabular}


July 12, 2011

Lab ID : : SP 1105923-004

Patty Frazer

Customer ID : 2-23787

Description : Control

WASHINGTON SOIL ANALYSIS

\begin{tabular}{|c|c|c|c|c|c|c|c|c|c|c|}
\hline Test Description & Result & Units & Optimum Range & \multicolumn{7}{|c|}{ Graphical Results Presentation } \\
\hline Others & \multirow[b]{2}{*}{$\begin{array}{l}1.10 \\
5.4 \\
1.0 \\
\end{array}$} & \multirow{3}{*}{$\begin{array}{c}\text { mmhos/cm } \\
\% \\
\end{array}$} & \multirow[b]{2}{*}{$\begin{array}{c}0.0-2.0 \\
0.0-6.0 \\
0.0-0.50 \\
\end{array}$} & \multicolumn{2}{|c|}{\begin{tabular}{l|l} 
Satisfactory & \\
\end{tabular}} & \multicolumn{2}{|c|}{\begin{tabular}{l|l}
$\begin{array}{l}\text { Possible } \\
\text { Problem }\end{array}$ & \\
\end{tabular}} & $\begin{array}{l}\text { Moderate } \\
\text { Problem }\end{array}$ & \multicolumn{2}{|c|}{$\begin{array}{c}\begin{array}{c}\text { Increasing } \\
\text { Problem }\end{array} \\
\end{array}$} \\
\hline $\begin{array}{l}\text { Soil Salinity } \\
\text { SAR } \\
\text { Limestone }\end{array}$ & & & & & & & & & & \\
\hline & & & \multirow[b]{2}{*}{--} & 0 & 1 & 2 & 3 & 4 & 5 & 6 \\
\hline Lime Requirement & 0 & Tons/AF & & & & & & & & \\
\hline \multirow[b]{2}{*}{ Moisture } & \multirow[b]{2}{*}{7.2} & \multirow[b]{2}{*}{$\%$} & \multirow[b]{2}{*}{$3.4-24$} & \multicolumn{3}{|c|}{\begin{tabular}{|c|}
$\begin{array}{c}\text { Moderately } \\
\text { Low }\end{array}$ \\
\end{tabular}} & Optimum & \multicolumn{2}{|c|}{\begin{tabular}{|c|}
$\begin{array}{c}\text { Moderately } \\
\text { High }\end{array}$ \\
\end{tabular}} & $\begin{array}{l}\text { Very } \\
\text { High }\end{array}$ \\
\hline & & & & & & & 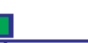 & & & \\
\hline \multirow[b]{2}{*}{ Saturation } & & & \multirow[b]{2}{*}{$40-50$} & $\begin{array}{l}\text { Loamy } \\
\text { Sand }\end{array}$ & $\begin{array}{l}\text { Sandy } \\
\text { Loam }\end{array}$ & Loam & \begin{tabular}{|c|} 
Silt \\
Loam
\end{tabular} & $\begin{array}{l}\text { Clay } \\
\text { Loam }\end{array}$ & Clay & Organic \\
\hline & 34.2 & $\%$ & & & & $\square$ & & & & \\
\hline \multirow[b]{2}{*}{ \% Organic Matter } & & & & \multicolumn{4}{|c|}{ Mineral } & \multicolumn{3}{|c|}{ Organic } \\
\hline & 1.43 & $\%$ & -- & $\square$ & & & & & & \\
\hline
\end{tabular}

Good $\quad$ Problem $\quad$ Indicates physical conditions and/or phenological and amendment requirements. Note: Color coded bar graphs have been used to provide you with 'AT-A-GLANCE' interpretations.

1) The need for soil Nitrate is dependant upon crop phenology (Growth Stage) and crop requirement. A soil Nitrate level of $10-40 \mathrm{ppm}$ is preferred for a short time during critical periods of uptake into the tree. It is highly desirable to have low soil Nitrate $(<5 \mathrm{ppm})$ prior to winter rainfall and cold soil conditions. Use the leaf Nitrogen level to determine primary Nitrogen requirement.

2) Trifoliate \& Citrumelo rootstocks are very sensitive to limestone and should not be planted in soils containing limestone. Other rootstock are moderately sensitive to limestone. Ascertain the rootstock tolerance prior to planting.

FRUIT GROWERS LABORATORY, INC.

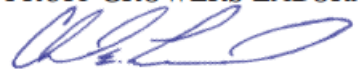

Chad Lessard, Director of Ag. Services 


\section{FRUIT GROWERS LABORATORY, INC.}

\section{Analytical Chemists}

www.fglinc.com

July 12, 2011

Patty Frazer

102 Ravenhill Road

Orinda, CA 94563

Description : Hurricane Effected Orchard Project

$$
\begin{array}{ll}
\text { Lab ID } & : \text { SP 1105923-007 } \\
\text { Customer ID } & : \text { 2-23787 } \\
\text { Sampled On } & : \text { May 23, 2011 } \\
\text { Sampled By } & \text { : Payton Carling } \\
\text { Received On } & \text { : June 13, 2011 } \\
\text { Depth } & : \text { N/A } \\
\text { Meth Irrg. } & :
\end{array}
$$

\begin{tabular}{|c|c|c|c|c|c|c|c|c|}
\hline Test Description & Result & Units & Optimum Range & & Graphical & esults Pre & entation & \\
\hline Primary Nutrients & & & & $\begin{array}{l}\text { Very } \\
\text { Low }\end{array}$ & $\begin{array}{c}\text { Moderately } \\
\text { Low }\end{array}$ & Optimum & $\begin{array}{c}\text { Moderately } \\
\text { High }\end{array}$ & $\begin{array}{l}\text { Very } \\
\text { High }\end{array}$ \\
\hline $\begin{array}{l}\text { Nitrate-Nitrogen } \\
\text { Phosphorus- } \mathrm{P}_{2} \mathrm{O}_{5} \\
\text { Potassium- } \mathrm{K}_{2} \mathrm{O} \text { (Exch) } \\
\text { Potassium- } \mathrm{K}_{2} \mathrm{O} \text { (Sol) }\end{array}$ & $\begin{array}{c}32.4 \\
55 \\
3670 \\
40.5\end{array}$ & $\begin{array}{l}\mathrm{Lbs} / \mathrm{AF} \\
\mathrm{Lbs} / \mathrm{AF} \\
\mathrm{Lbs} / \mathrm{AF} \\
\mathrm{Lbs} / \mathrm{AF}\end{array}$ & $\begin{array}{c}40-80 \\
140-280 \\
1000-6300 \\
94-470\end{array}$ & $\square$ & & & & \\
\hline $\begin{array}{l}\text { Secondary Nutrients } \\
\text { Calcium (Exch) } \\
\text { Calcium (Sol) } \\
\text { Magnesium (Exch) } \\
\text { Magnesium (Sol) } \\
\text { Sodium (Exch) } \\
\text { Sodium (Sol) } \\
\text { Sulfate } \\
\end{array}$ & $\begin{array}{c}26100 \\
156 \\
7870 \\
114 \\
4880 \\
1280 \\
507 \\
\end{array}$ & $\begin{array}{l}\mathrm{Lbs} / \mathrm{AF} \\
\mathrm{Lbs} / \mathrm{AF} \\
\mathrm{Lbs} / \mathrm{AF} \\
\mathrm{Lbs} / \mathrm{AF} \\
\mathrm{Lbs} / \mathrm{AF} \\
\mathrm{Lbs} / \mathrm{AF} \\
\mathrm{Lbs} / \mathrm{AF}\end{array}$ & $\begin{array}{c}27000-36000 \\
160-640 \\
2700-5400 \\
73-220 \\
0.0-2600 \\
0.0-810 \\
120-3800 \\
\end{array}$ & & & $\square_{13 \%}$ & $\square$ & \\
\hline $\begin{array}{l}\text { Micro Nutrients } \\
\text { Zinc } \\
\text { Manganese } \\
\text { Iron } \\
\text { Copper } \\
\text { Boron } \\
\text { Chloride }\end{array}$ & $\begin{array}{l}1.20 \\
18.0 \\
39.6 \\
3.60 \\
4.24 \\
1080\end{array}$ & $\begin{array}{l}\mathrm{Lbs} / \mathrm{AF} \\
\mathrm{Lbs} / \mathrm{AF} \\
\mathrm{Lbs} / \mathrm{AF} \\
\mathrm{Lbs} / \mathrm{AF} \\
\mathrm{Lbs} / \mathrm{AF} \\
\mathrm{Lbs} / \mathrm{AF}\end{array}$ & $\begin{array}{l}4.0-160 \\
6.0-240 \\
40-200 \\
1.2-41 \\
1.2-8.4 \\
14-660\end{array}$ & & & | & & \\
\hline CEC & 56.0 & meq $/ 100 \mathrm{~g}$ & $14-35$ & & & & & \\
\hline $\begin{array}{l}\% \text { Base Saturation } \\
\text { CEC - Calcium } \\
\text { CEC - Magnesium } \\
\text { CEC - Potassium } \\
\text { CEC - Sodium } \\
\text { CEC - Hydrogen }\end{array}$ & $\begin{array}{l}58.0 \\
28.9 \\
3.48 \\
9.48 \\
0.00 \\
\end{array}$ & $\begin{array}{l}\% \\
\% \\
\% \\
\% \\
\%\end{array}$ & $\begin{array}{c}60-80 \\
10-20 \\
1.0-6.0 \\
0.0-5.0 \\
0.0-3.0\end{array}$ & & & & & \\
\hline \multirow[b]{2}{*}{$\mathrm{pH}$} & \multirow[b]{2}{*}{8.34} & \multirow[b]{2}{*}{--} & \multirow[b]{2}{*}{$6.0-7.5$} & $\begin{array}{l}\text { Strongly } \\
\text { Acidic }\end{array}$ & $\begin{array}{l}\text { Moderately } \\
\text { Acidic }\end{array}$ & $\begin{array}{c}\text { Near } \\
\text { Neutral }\end{array}$ & $\begin{array}{l}\text { Moderately } \\
\text { Alkaline }\end{array}$ & 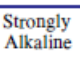 \\
\hline & & & & & & & & \\
\hline
\end{tabular}

WASHINGTON SOIL ANALYSIS

Good $\quad$ Problem Indicates physical conditions and/or phenological and amendment requirements. Note: Color coded bar graphs have been used to provide you with 'AT-A-GLANCE' interpretations.

\begin{tabular}{lllll}
\hline Corporate Offices \& Laboratory & Office \& Laboratory & Office \& Laboratory & Office \& Laboratory & Field Office \\
853 Corporation Street & 2500 Stagecoach Road & 563 East Lindo Avenue & 3442 Empresa Drive, Suite D & Visalia, California \\
Santa Paula, CA 93060 & Stockton, CA 95215 & Chico, CA 95926 & San Luis Obispo, CA 93401 & TEL: (559) 734-9473 \\
TEL: (805) 392-2000 & TEL: (209) 942-0182 & TEL: (530) 343-5818 & TEL: (805) 783-2940 & FAX: (559) 734-8435 \\
FAX: (805) 392-2063 & FAX: (209) $942-0423$ & FAX: (530) 343-3807 & FAX: (805) 392-2063 & Mobile: (559) 737-2399
\end{tabular}


July 12,2011

Lab ID : : SP 1105923-007

Patty Frazer

Customer ID : 2-23787

Description : Hurricane Effected Orchard

WASHINGTON SOIL ANALYSIS

\begin{tabular}{|c|c|c|c|c|c|c|c|c|c|c|}
\hline Test Description & Result & Units & Optimum Range & \multicolumn{7}{|c|}{ Graphical Results Presentation } \\
\hline Others & \multirow{5}{*}{$\begin{array}{l}1.87 \\
9.5 \\
2.1 \\
\end{array}$} & \multirow{4}{*}{$\begin{array}{c}\text { mmhos } / \mathrm{cm} \\
\% \\
\end{array}$} & \multirow{5}{*}{$\begin{array}{r}0.0-2.0 \\
0.0-6.0 \\
0.0-0.50 \\
\end{array}$} & \multicolumn{2}{|c|}{\begin{tabular}{l|l} 
Satisfactory & \\
\end{tabular}} & \multicolumn{2}{|c|}{\begin{tabular}{l|l}
$\begin{array}{l}\text { Possible } \\
\text { Problem }\end{array}$ & \\
\end{tabular}} & $\begin{array}{c}\begin{array}{c}\text { Moderate } \\
\text { Problem }\end{array} \\
\end{array}$ & \multicolumn{2}{|c|}{$\begin{array}{c}\text { Increasing } \\
\text { Problem } \\
\end{array}$} \\
\hline Soil Salinity & & & & & & & & & & \\
\hline SAR & & & & & & & & & & \\
\hline Limestone & & & & & & $\square$ & & & & \\
\hline & & \multirow[b]{2}{*}{ Tons/AF } & & 0 & 1 & 2 & 3 & 4 & 5 & 6 \\
\hline Lime Requirement & 0 & & --- & & & & & & & \\
\hline \multirow[b]{2}{*}{ Moisture } & \multirow[b]{2}{*}{4.2} & \multirow[b]{2}{*}{$\%$} & \multirow[b]{2}{*}{$3.5-25$} & \multicolumn{3}{|c|}{\begin{tabular}{|c|}
$\begin{array}{c}\text { Moderately } \\
\text { Low }\end{array}$ \\
\end{tabular}} & Optimum & \multirow{2}{*}{\multicolumn{2}{|c|}{$\begin{array}{c}\begin{array}{c}\text { Moderately } \\
\text { High }\end{array} \\
\end{array}$}} & $\begin{array}{l}\text { Very } \\
\text { High }\end{array}$ \\
\hline & & & & & & & & & & \\
\hline \multirow[b]{2}{*}{ Saturation } & & & \multirow[b]{2}{*}{$40-50$} & $\begin{array}{l}\text { Loamy } \\
\text { Sand }\end{array}$ & $\begin{array}{l}\text { Sandy } \\
\text { Loam }\end{array}$ & Loam & $\begin{array}{c}\begin{array}{c}\text { Silt } \\
\text { Loam }\end{array} \\
\text { L }\end{array}$ & $\begin{array}{l}\text { Clay } \\
\text { Loam }\end{array}$ & Clay & Organic \\
\hline & 35.2 & $\%$ & & & & $\square$ & & & & \\
\hline \multirow[b]{2}{*}{ \% Organic Matter } & & & & \multicolumn{4}{|c|}{ Mineral } & \multicolumn{3}{|c|}{ Organic } \\
\hline & 1.71 & $\%$ & -- & $\square$ & & & & & & \\
\hline
\end{tabular}

Good $\quad$ Problem $\quad$ Indicates physical conditions and/or phenological and amendment requirements. Note: Color coded bar graphs have been used to provide you with 'AT-A-GLANCE' interpretations.

1) The need for soil Nitrate is dependant upon crop phenology (Growth Stage) and crop requirement. A soil Nitrate level of $10-40 \mathrm{ppm}$ is preferred for a short time during critical periods of uptake into the tree. It is highly desirable to have low soil Nitrate $(<5 \mathrm{ppm})$ prior to winter rainfall and cold soil conditions. Use the leaf Nitrogen level to determine primary Nitrogen requirement.

2) Trifoliate \& Citrumelo rootstocks are very sensitive to limestone and should not be planted in soils containing limestone. Other rootstock are moderately sensitive to limestone. Ascertain the rootstock tolerance prior to planting.

FRUIT GROWERS LABORATORY, INC.

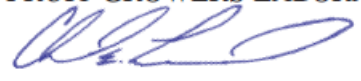

Chad Lessard, Director of Ag. Services 


\section{Pint FRUIT GROWERS LABORATORY, INC.}

July 12, 2011

Patty Frazer

102 Ravenhill Road

Orinda, CA 94563

Description : Worm Castings

Project :Payton Carling/Cal Poly Thesis

ORGANIC AMENDMENT ANALYSIS

\begin{tabular}{|c|c|c|c|c|c|}
\hline Constituent & Units & Dried & As Received & $\begin{array}{l}\text { Lbs./cu.yd As } \\
\text { Received }\end{array}$ & $\begin{array}{l}\text { Lbs./Ton As } \\
\text { Received }\end{array}$ \\
\hline Total Nitrogen & $\%$ & 1.95 & 0.796 & 7.45 & 15.9 \\
\hline Total Phosphorus $\left(\mathrm{P}_{2} \mathrm{O}_{5}\right)$ & $\%$ & 1.63 & 0.665 & 6.23 & 13.3 \\
\hline Total Potassium $\left(\mathrm{K}_{2} \mathrm{O}\right)$ & $\%$ & 1.29 & 0.526 & 4.93 & 10.5 \\
\hline Total Chloride & $\%$ & 0.225 & 0.0918 & 0.86 & 1.84 \\
\hline Total Sodium & $\%$ & 0.286 & 0.117 & 1.09 & 2.33 \\
\hline Boron & ppm & 77.2 & 31.5 & 0.0295 & 0.063 \\
\hline Calcium & $\%$ & 2.90 & 1.18 & 11.1 & 23.7 \\
\hline Magnesium & $\%$ & 0.938 & 0.383 & 3.59 & 7.65 \\
\hline Zinc & ppm & 50.3 & 20.5 & 0.0192 & 0.041 \\
\hline Manganese & $\mathrm{ppm}$ & 259 & 106 & 0.099 & 0.211 \\
\hline Iron & $\mathrm{ppm}$ & 2600 & 1060 & 0.994 & 2.12 \\
\hline Copper & $\mathrm{ppm}$ & 17 & 6.94 & 0.0065 & 0.0139 \\
\hline Salinity (EC) & $\mathrm{mmhos} / \mathrm{cm}$ & & 10.1 & & \\
\hline $\mathrm{pH}$ & units & & 8.39 & & \\
\hline Moisture & $\%$ & & 59.2 & & \\
\hline Organic Matter & $\%$ & 40.8 & 16.6 & & \\
\hline Ash & $\%$ & 59.2 & 24.2 & & \\
\hline Bulk Density & Lbs/yd3 & & 937 & & \\
\hline Carbon & $\%$ & 23.6 & 9.63 & 90.2 & 193 \\
\hline Carbon:Nitrogen & Ratio & & 12.1 & & \\
\hline
\end{tabular}

Lab ID : SP 1105923-005

Customer ID : 2-23787

Sampled On : May 23, 2011-:

Sampled By : Payton Carling

Received On : June 13, 2011-16:00

Matrix : Compost 
FRUIT GROWERS LABORATORY, INC.

Analytical Chemists

July 12, 2011

Patty Frazer

102 Ravenhill Road

Orinda, CA 94563

Description : Compost

Project : Payton Carling/Cal Poly Thesis

ORGANIC AMENDMENT ANALYSIS

\begin{tabular}{||l|c|c|c|c|c||}
\hline Constituent & Units & Dried & As Received & $\begin{array}{c}\text { Lbs./cu.yd As } \\
\text { Received }\end{array}$ & $\begin{array}{c}\text { Lbs./Ton As } \\
\text { Received }\end{array}$ \\
\hline \hline Total Nitrogen & $\%$ & 1.10 & 0.793 & 6.32 & 15.9 \\
Total Phosphorus $\left(\mathrm{P}_{2} \mathrm{O}\right.$ s) & $\%$ & 1.44 & 1.04 & 8.27 & 20.8 \\
Total Potassium $\left(\mathrm{K}_{2} \mathrm{O}\right)$ & $\%$ & 1.09 & 0.786 & 6.26 & 15.7 \\
Total Chloride & $\%$ & 0.225 & 0.162 & 1.29 & 3.24 \\
Total Sodium & $\%$ & 0.240 & 0.173 & 1.38 & 3.46 \\
Boron & $\mathrm{ppm}$ & 39.1 & 28.2 & 0.0225 & 0.0564 \\
Calcium & $\%$ & 3.23 & 2.33 & 18.6 & 46.6 \\
Magnesium & $\%$ & 0.571 & 0.412 & 3.28 & 8.23 \\
Zinc & $\mathrm{ppm}$ & 41.0 & 29.6 & 0.0236 & 0.0591 \\
Manganese & $\mathrm{ppm}$ & 212 & 153 & 0.122 & 0.306 \\
Iron & $\mathrm{ppm}$ & 2810 & 2030 & 1.61 & 4.05 \\
Copper & $\mathrm{ppm}$ & 11.9 & 8.58 & 0.00684 & 0.0172 \\
Salinity (EC) & $\mathrm{mmhs} / \mathrm{cm}$ & & 16.4 & & \\
pH & units & & 7.52 & & \\
Moisture & $\%$ & & 27.9 & & \\
Organic Matter & $\%$ & 16.3 & 11.8 & & \\
Ash & $\%$ & 83.7 & 60.3 & & \\
Bulk Density & Lbs/yd3 & & 797 & & \\
Carbon & $\%$ & 9.47 & 6.83 & 54.4 & \\
Carbon:Nitrogen & Ratio & & 8.61 & & \\
\hline \hline
\end{tabular}

Lab ID : SP 1105923-006

Customer ID : 2-23787

Sampled On : May 23, 2011-:

Sampled By : Payton Carling

Received On : June 13, 2011-16:00

Matrix : Compost 


\section{FRUIT GROWERS LABORATORY, INC.}

Analytical Chemists

June 9, 2011

Patty Frazer

102 Ravenhill Road

Orinda, CA 94563

Description : C +VTF Navel

Project : Payton Carling/Cal Poly Thesis
Lab ID : : SP 1105542-001

Customer ID : 2-23787

Sampled On : May 27, 2011

Sampled By : Payton Carling

Received On : June 6, 2011

Age : Mature

Meth Irrg. :

WASHINGTON PLANT TISSUE ANALYSIS

\begin{tabular}{|c|c|c|c|c|c|c|c|c|}
\hline Test Description & Result & Units & Optimum Range & \multicolumn{5}{|c|}{ Graphical Results Presentation } \\
\hline Macro Nutrients & & & & Deficient & Low & Ample & High & Excessive \\
\hline Total Nitrogen (Leaf) & 2.60 & $\%$ & $2.6-2.8$ & & & & & \\
\hline Phosphorus (Leaf) & 0.53 & $\%$ & $0.12-0.21$ & & & & & \\
\hline Potassium (Leaf) & 1.38 & $\%$ & $0.70-3.3$ & & & & & \\
\hline Calcium (Leaf) & 4.14 & $\%$ & $3.0-5.5$ & & & & & \\
\hline Magnesium (Leaf) & 0.41 & $\%$ & $0.26-0.60$ & & & & & \\
\hline Micro Nutrients & & & & & & & & \\
\hline Zinc (Leaf) & 16.5 & $\mathrm{ppm}$ & $25-200$ & & J & & & \\
\hline Manganese (Leaf) & 19 & $\mathrm{ppm}$ & $25-300$ & & $\square$ & & & \\
\hline Iron (Leaf) & 44 & $\mathrm{ppm}$ & $60-200$ & & $\square$ & & & \\
\hline Copper (Leaf) & 12 & ppm & $5.0-40$ & & & & & \\
\hline Boron (Leaf) & 160 & ppm & $31-300$ & & & & & \\
\hline Sodium (Leaf) & 0.222 & $\%$ & $0.0-0.16$ & & & & & \\
\hline
\end{tabular}

Good 1 Problem $\quad$ Indicates physical conditions andior phenologikal and amendment requirements.

Note: Color coded bar graphs have been used to provide you with 'AT-A-GL-ANCE' interprecacions.

These standards are based on a dry weight basis in 5 to 7 month old navels, bloom cycle leaves from non-fruiting, non-flushing terminals. Adapted and revised from Jones and Embleton, University of California. The optimum range for total nitrogen in navel oranges as listed is based on FGL laboratory information and is higher than that for valencia oranges. All leaves and/or petioles are thoroughly washed prior to drying.

FRUIT GROWERS LABORATOKY, INC

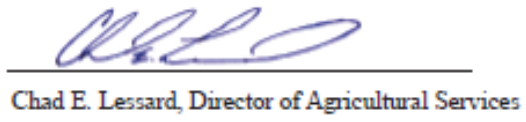

\begin{tabular}{ll}
\hline Corporate Omooc \& Laboratory & Ornoo \& Laboratory \\
853 Corporatlon 3treet & 2500 Otagecosch Rosd \\
Santa Paula, CA 93060 & Otockton, CA 95215 \\
TEL: (805) 392-2000 & TEL: (209) 942-0182 \\
FAX: (805) 392-2063 & FAX: (209) 942-0423
\end{tabular}

Omloo \& Laboratory
563 East Lindo Avenue
Chico, CA 95926
TEL: (530) $343-5818$
FAX: $(530) 343-3807$

Omloo \& Laboratory 3442 Empreas Drive, Sulte D

Oan Lula Obispo, CA 93401

FAX: (805) 392-2063

Fleid Otnos

TEL: (209) 942-018

FAX: (530) 343-3807

TEL: (559) $734-9473$

FAX: (559) 734-8435

TEL: (805) 392-2000

Fix: (209) 9420423

Page 66 
June 9, 2011

Patty Frazer

102 Ravenhill Road

Orinda, CA 94563

Description : GMCC+VTF Navel

Project : Payton Carling/Cal Poly Thesis
Lab ID : : SP 1105542-002

Customer ID : 2-23787

Sampled On : May 27, 2011

Sampled By : Payton Carling

Received On : June 6, 2011

Age : Mature

Meth Irrg. :

\section{WASHINGTON PLANT TISSUE ANALYSIS}

\begin{tabular}{|c|c|c|c|c|c|c|c|c|}
\hline \multirow{7}{*}{$\begin{array}{l}\text { Test Description } \\
\text { Macro Nutrients } \\
\text { Total Nitrogen (Leaf) } \\
\text { Phosphorus (Leaf) } \\
\text { Potassium (Leaf) } \\
\text { Calcium (Leaf) } \\
\text { Magnesium (Leaf) } \\
\end{array}$} & Result & Units & Optimum Range & \multicolumn{5}{|c|}{ Graphical Results Presentation } \\
\hline & \multirow{6}{*}{$\begin{array}{l}2.48 \\
0.51 \\
1.64 \\
3.69 \\
0.38 \\
\end{array}$} & \multirow[b]{2}{*}{$\%$} & \multirow[b]{2}{*}{$2.6-2.8$} & Deficient & Low & Ample & Hight & Excessive \\
\hline & & & & & $\square$ & & & \\
\hline & & $\%$ & $0.12-0.21$ & & & & & \\
\hline & & $\%$ & $0.70-3.3$ & & & & & \\
\hline & & $\%$ & $3.0-5.5$ & & & & & \\
\hline & & $\%$ & $0.26-0.60$ & & & & & \\
\hline Micro Nutrients & & & & & & & & \\
\hline Zinc (Leaf) & 16.3 & ppm & $25-200$ & & & & & \\
\hline Manganese (Leaf) & 22 & ppm & $25-300$ & & & & & \\
\hline Iron (Leaf) & 43 & ppm & $60-200$ & & $コ$ & & & \\
\hline Copper (Leaf) & 11 & $\mathrm{ppm}$ & $5.0-40$ & & & & & \\
\hline Boron (Leaf) & 134 & $\mathrm{ppm}$ & $31-300$ & & & 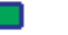 & & \\
\hline Sodium (Leaf) & 0.151 & $\%$ & $0.0-0.16$ & & & & & \\
\hline
\end{tabular}

Good Problem Indicates physical conditions and/or phenological and amendment requirements.

Note: Color coded bar graphs have been used to provide you with 'AT-A-GL.ANCE' interpretacions.

These standards are based on a dry weight basis in 5 to 7 month old navels, bloom cycle leaves from non-fruiting, non-flushing terminals. Adapted and revised from Jones and Embleton, University of California. The optimum range for total nitrogen in navel oranges as listed is based on FGL laboratory information and is higher than that for valencia oranges. All leaves and/or petioles are thoroughly washed prior to drying.

FRUIT GROWERS LABORATOKY, INC

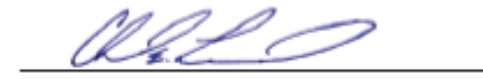

Chad E. Lessard, Director of Agricultural Services

\begin{tabular}{|c|c|c|c|c|}
\hline $\begin{array}{l}\text { Corporato Omose \& Laboratory } \\
\text { 853 Corporation Otreet } \\
\text { Santa Paula, CA } 93060 \\
\text { TEL: (805) 392-2000 }\end{array}$ & $\begin{array}{l}\text { Ofnoo \& Laboratory } \\
2500 \text { otagecosch Road } \\
\text { Otockton, C. 95215 } \\
\text { TEL: (209) 942-0182 }\end{array}$ & $\begin{array}{l}\text { Offloo \& Laboratory } \\
563 \text { East LIndo Avenue } \\
\text { Chico, CA } 95926 \\
\text { TEL: (530) 343-5818 }\end{array}$ & $\begin{array}{l}\text { Omlioe \& Laboratory } \\
3442 \text { Empress Drive, sulte D } \\
\text { Oan Lula Oblspo, CA } 93401 \\
\text { TEL- (805) } 783-2940\end{array}$ & $\begin{array}{l}\text { Flold Othloo } \\
\text { Vizalls, Calfornls } \\
\text { TEL: (559) 734-9473 } \\
\text { FAX: (559) 734-8435 }\end{array}$ \\
\hline FAX: (805) $392-2063$ & FAX: (209) 942-0423 & FAX: $(530)$ 343-3807 & FAX: (805) 392-2063 & Moblle: (559) $737-2399$ \\
\hline
\end{tabular}


June 9, 2011

Patty Frazer

102 Ravenhill Road

Orinda, CA 94563

Description : VTF Navel

Project : Payton Carling/Cal Poly Thesis
Lab ID : SP 1105542-003

Customer ID : 2-23787

Sampled On : May 27, 2011

Sampled By : Payton Carling

Received On : June 6, 2011

Age : Mature

Meth Irrg. :

WASHINGTON PLANT TISSUE ANALYSIS

\begin{tabular}{|c|c|c|c|c|c|c|c|c|}
\hline \multirow{7}{*}{$\begin{array}{l}\text { Test Description } \\
\text { Macro Nutrients } \\
\text { Total Nitrogen (Leaf) } \\
\text { Phosphorus (Leaf) } \\
\text { Potassium (Leaf) } \\
\text { Calcium (Leaf) } \\
\text { Magnesium (Leaf) }\end{array}$} & Result & Units & Optimum Range & \multicolumn{5}{|c|}{ Graphical Results Presentation } \\
\hline & & & & Deficient & Low & Ample & High & Excessive \\
\hline & 2.33 & $\%$ & $2.6-2.8$ & & & & & \\
\hline & 0.42 & $\%$ & $0.12-0.21$ & & & & & \\
\hline & 1.54 & $\%$ & $0.70-3.3$ & & & & & \\
\hline & 3.78 & $\%$ & $3,0-5.5$ & & & & & \\
\hline & 0.40 & $\%$ & $0.26-0.60$ & & & & & \\
\hline Micro Nutrients & & & & & & & & \\
\hline Zinc (Leaf) & 14.6 & ppm & $25-200$ & & & & & \\
\hline Manganese (Leaf) & 22 & $\mathrm{ppm}$ & $25-300$ & & & & & \\
\hline Iron (Leaf) & 45 & ppm & $60-200$ & & & & & \\
\hline Copper (Leaf) & 10 & $\mathrm{ppm}$ & $5.0-40$ & & & & & \\
\hline Boron (Leaf) & 143 & ppm & $31-300$ & & & & & \\
\hline Sodium (Leaf) & 0.234 & $\%$ & $0.0-0.16$ & & & & & \\
\hline
\end{tabular}

Good

Problem

Indicates physical condicions and/or phenological and amendment requirements.

Note: Color coded bar graphs have been used to peovide you with 'AT-A-GL-ANCE' interpretacions.

These standards are based on a dry weight basis in 5 to 7 month old navels, bloom cycle leaves from non-fruiting, non-flushing terminals. Adapted and revised from Jones and Embleton, University of California. The optimum range for total nitrogen in navel oranges as listed is based on FGL laboratory information and is higher than that for valencia oranges. All leaves and/or petioles are thoroughly washed prior to drying.

FRUIT GROWERS LABORATOKY, INC

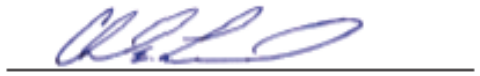

Chad E. Lessard, Director of Agricultural Services 


\section{FRUIT GROWERS LABORATORY, INC.}

Analytical Chemists

www.fglinc.com

Patty Frazer

102 Ravenhill Road

Orinda, CA 94563

Description : Control Navel

Project : Payton Carling/Cal Poly Thesis
June 9, 2011

Lab ID : SP 1105542-004

Customer ID : 2-23787

Sampled On : May 27, 2011

Sampled By : Payton Carling

Received On : June 6, 2011

Age : Mature

Meth Irrg. :

WASHINGTON PLANT TISSUE ANALYSIS

\begin{tabular}{|c|c|c|c|c|c|c|c|c|}
\hline Test Description & Result & Units & Optimum Range & \multicolumn{5}{|c|}{ Graphical Results Presentation } \\
\hline Macro Nutrients & & & & Deficient & Low & Ample & High & Excessive \\
\hline Total Nitrogen (Leaf) & 1.89 & $\%$ & $2.6-2.8$ & & & & & \\
\hline Phosphorus (Leaf) & 0.56 & $\%$ & $0.12-0.21$ & & & & & \\
\hline Potassium (Leaf) & 1.21 & $\%$ & $0.70-3.3$ & & & & & \\
\hline Calcium (Leaf) & 4.64 & $\%$ & $3.0-5.5$ & & & & & \\
\hline Magnesium (Leaf) & 0.42 & $\%$ & $0.26-0.60$ & & & & & \\
\hline Micro Nutrients & & & & & & & & \\
\hline Zinc (Leaf) & 15.0 & ppm & $25-200$ & & & & & \\
\hline Manganese (Leaf) & 22 & $\mathrm{ppm}$ & $25-300$ & & & & & \\
\hline Iron (Leaf) & 46 & $\mathrm{ppm}$ & $60-200$ & & $\square$ & & & \\
\hline Copper (Leaf) & 11 & $\mathrm{ppm}$ & $5.0-40$ & & & & & \\
\hline Boron (Leaf) & 182 & $\mathrm{ppm}$ & $31-300$ & & & & & \\
\hline Sodium (Leaf) & 0.117 & $\%$ & $0.0-0.16$ & & & & & \\
\hline
\end{tabular}

Good $\quad$ Problem $\quad$ Indicates physical condicions andior phenological and amendment requirements.

Note: Color coded bar graphs have been used to provide you with 'AT-A-GL.ANCE' interpretacions.

These standards are based on a dry weight basis in 5 to 7 month old navels, bloom cycle leaves from non-fruiting, non-flushing terminals. Adapted and revised from Jones and Embleton, University of California. The optimum range for total nitrogen in navel oranges as listed is based on FGL laboratory information and is higher than that for valencia oranges. All leaves and/or petioles are thoroughly washed prior to drying.

FRUIT GROWERS LABORATOKY, INC

CEL:JRJ

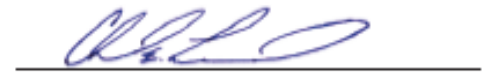

Chad E. Lessard, Director of Agricultural Services

\begin{tabular}{|c|c|c|c|c|}
\hline $\begin{array}{l}\text { Corporate Omooc \& Laboratory } \\
853 \text { Corporation Btreet } \\
\text { Oanta Pauls, CA } 93060\end{array}$ & $\begin{array}{l}\text { Ofnoe \& Laboratory } \\
2500 \text { Stagecosch Road } \\
\text { Otockton, CA 95215 }\end{array}$ & $\begin{array}{l}\text { Omlos \& Laboratory } \\
563 \text { East Lindo Avenue } \\
\text { Chico, CA } 95926\end{array}$ & $\begin{array}{l}\text { Omloo \& Laboratory } \\
3442 \text { Empress Dorlve, Sulte D } \\
\text { Pan Lula Oblspo, CA } 93401\end{array}$ & $\begin{array}{l}\text { Flold Othoo } \\
\text { Visalla, Calfornla } \\
\text { TEL: (559) 734-9473 }\end{array}$ \\
\hline TEL: (805) 392-2000 & TEL: (209) 942-0182 & TEL: (530) 343-5818 & TEL: (805) 783-2940 & FAX: (559) 734-8435 \\
\hline FAX: (805) $392-2063$ & FAX: $(209) 942-0423$ & FAX: $(530) 343-3807$ & FAX: (805) 392-2063 & Moblle: (559) $737-2399$ \\
\hline
\end{tabular}




\section{FRUIT GROWERS LABORATORY, INC}

Analytical Chemists

May 24, 2011

Patty Frazer

102 Ravenhill Road

Orinda, CA 94563

Description : San Isidro Canal Water

Project : Cal Poly SLO Masters Thesis
Lab ID : : SP 1104701-002

Customer ID : 2-23787

Sampled On :

Sampled By : Payton Carling

Received On : May 12, 2011

Matrix : Non Potable Water

General Irrigation Suitability Analysis

\begin{tabular}{|c|c|c|c|c|c|c|c|c|c|}
\hline \multirow{2}{*}{$\begin{array}{l}\text { Test Description } \\
\text { Cations }\end{array}$} & \multicolumn{4}{|c|}{ Result } & \multicolumn{5}{|c|}{ Graphical Results Presentation } \\
\hline & $\mathrm{mg} / \mathrm{L}$ & $\mathrm{Me} q / \mathrm{L}$ & $\%$ Meq & \multirow{5}{*}{$\begin{array}{c}\mathrm{Lbs} / \mathrm{AF} \\
60 \\
52 \\
11 \\
310 \\
\end{array}$} & Good & $\begin{array}{l}\text { Possible } \\
\text { Problem }\end{array}$ & $\begin{array}{l}\text { Moderale } \\
\text { Problem }\end{array}$ & $\begin{array}{l}\text { Increasing } \\
\text { Problem }\end{array}$ & $\begin{array}{c}\text { Severe } \\
\text { Problem }\end{array}$ \\
\hline Calcium & 22 & 1.1 & 14 & & ** & & & & \\
\hline Magnesium & 19 & 1.6 & 20 & & $* *$ & & & & \\
\hline Potassium & 4 & 0.1 & 1 & & $* *$ & & & & \\
\hline Sodium & 114 & 5 & 64 & & & & & & \\
\hline \multirow{7}{*}{$\begin{array}{l}\text { Anions } \\
\text { Carbonate } \\
\text { Bicarbonate } \\
\text { Sulfate } \\
\text { Chloride } \\
\text { Nitrate } \\
\text { Fluoride } \\
\end{array}$} & & & & & & & & & \\
\hline & $<10$ & 0 & 0 & 0 & & & & & \\
\hline & 220 & 3.6 & 48 & 600 & ** & & & & \\
\hline & 19 & 0.4 & 5 & 52 & $* 8$ & & & & \\
\hline & 121 & 3.4 & 46 & 330 & & & & & \\
\hline & $<0,4$ & 0 & 0 & 0 & & & & & \\
\hline & 0.5 & 0.026 & 0 & 1 & & & & & \\
\hline \multirow{7}{*}{$\begin{array}{l}\text { Minor Elements } \\
\text { Boron } \\
\text { Copper } \\
\text { Iron } \\
\text { Manganese } \\
\text { Zinc } \\
\text { TDS by Summation } \\
\end{array}$} & & & & & & & & & \\
\hline & 0.40 & & & 1.1 & & & & & \\
\hline & $<0.01$ & & & 0.00 & & & & & \\
\hline & $<0.05$ & & & 0,00 & & & & & \\
\hline & 0,020 & & & 0.054 & & & & & \\
\hline & 0,040 & & & 0.11 & & & & & \\
\hline & 520 & & & 1400 & & & & & \\
\hline \multirow{4}{*}{$\begin{array}{l}\text { Other } \\
\text { pH } \\
\text { E. C. } \\
\text { SAR } \\
\end{array}$} & & & & & & & & & \\
\hline & 8.2 & & & units & & & & & \\
\hline & 766 & & & umhos $/ \mathrm{cm}$ & & & & & \\
\hline & 4.3 & & & & & & & & \\
\hline \multirow{3}{*}{$\begin{array}{l}\text { Crop Suitability } \\
\text { No Amendments } \\
\text { With Amendments }\end{array}$} & & & & & & & & & \\
\hline & Fair & & & & & & & & \\
\hline & Fair & & & & & & & & \\
\hline \multirow{4}{*}{$\begin{array}{l}\text { Amendments } \\
\text { Gypsum Requirement } \\
\text { Sulfuric Acid ( } 98 \% \text { ) } \\
\text { Leaching Requirement }\end{array}$} & & & & & \multirow{4}{*}{\multicolumn{5}{|c|}{$\begin{array}{l}\text { Do not apply if Sulfuric Acid amendment is applied, } \\
\text { Or } 30 \mathrm{oz} / 1000 \mathrm{Gal} \text { of urea Sulfuric Acid }(15 / 49) \text {. }\end{array}$}} \\
\hline & 0.7 & & & Tons/AF & & & & & \\
\hline & 13 & & & $\mathrm{oz} / 1000 \mathrm{Gal}$ & & & & & \\
\hline & 5.8 & & & $\%$ & & & & & \\
\hline
\end{tabular}

Good $\quad$ Problem $\quad$ Indicales physical condicions and/or phenological and amendment requirements.

Note: Color coded bar graphs have been used to provide you with 'AT-A-GL_ANCE' interprecacions. 
May 24, 2011

Lab ID : : SP 1104701-002

Patty Frazer

Customer ID : 2-23787

Description : San Isidro Canal Water

Micro Irrigation System Plugging Hazard

\begin{tabular}{|c|c|c|c|c|c|}
\hline \multirow{3}{*}{$\begin{array}{l}\text { Test Description } \\
\text { Chemical } \\
\text { Manganese } \\
\text { Iron } \\
\text { TDS by Summation }\end{array}$} & \multicolumn{2}{|c|}{ Result } & \multicolumn{3}{|c|}{ Graphical Results Presentation } \\
\hline & & & Slipht & Moderate & Severe \\
\hline & $\begin{array}{l}0.02 \\
<0.05 \\
520\end{array}$ & $\begin{array}{l}\mathrm{mg} / \mathrm{L} \\
\mathrm{mg} / \mathrm{L} \\
\mathrm{mg} / \mathrm{L}\end{array}$ & & & \\
\hline $\begin{array}{l}\text { No Amendments } \\
\mathrm{pH}\end{array}$ & 8.2 & units & & & \\
\hline Alkalinity & 180 & $\mathrm{mg} / \mathrm{L}$ & & & \\
\hline Total Hardness & 133 & $\mathrm{mg} / \mathrm{L}$ & & & \\
\hline $\begin{array}{l}\text { With Amendments } \\
\text { Alkalinity } \\
\text { Total Hardness } \\
\text { pH }\end{array}$ & $\begin{array}{c}36 \\
36 \\
5.4-6.7\end{array}$ & $\begin{array}{l}\mathrm{mg} / \mathrm{L} \\
\mathrm{mg} / \mathrm{L} \\
\text { units }\end{array}$ & & & \\
\hline
\end{tabular}

Good Problem Indicates physical conditions asd/or phenological and amendment requirements.

Note: Color coded bar graphs have been used to provide you with 'AT-A-GLANCE' interpeetacions.

Water Amendments Application Notes:

The Amendments recommended on the previous pages include:

Gypsum:

This should be applied at least once a year to the irrigated soil surface area. Gypsum can also be applied in smaller quantities in the irrigation water. Apply the smaller (bracketed) amount of gypsum when also applying the recommended amount of Sulfuric Acid and the larger amount when applying only Gypsum.

Sulfuric Acid:

These products should be applied as needed to prevent emitter plugging in micro irrigation systems and/or as a soil amendment to adjust soil $\mathrm{pH}$ to improve nutrient availability and to facilitate leaching of salts. Please exercise caution when using this material as excesses may be harmful to the system and/or the plants being irrigated.

The reported Acid requirement is intended to remove approximately $80 \%$ of the alkalinity. The final pH should range from 5.4 to 6.7 . We recommend a field $\mathrm{pH}$ determination to confirm that the $\mathrm{pH}$ you designate is being achieved. This application is based upon the use of a $98 \%$ Sulfuric Acid product. The application of Urea Sulfuric Acid is based upon the use of a product that contains $15 \%$ Urea (1.89 lbs Nitrogen), $49 \%$ Sulfuric Acid and has a specific gravity of 1.52 at $68{ }^{\circ} \mathrm{F}$.

Guidelines for the above interpretations are sourced from USDA \& U.C. Cooperative Extension Service publications. Please contact us if you have any questions.

CEL:EHB
FRUIT GROWERS LABORATORY, INC.

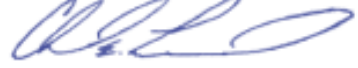

Chad Lessard, Director of Ag. Services 
Patty Frazer

102 Ravenhill Road

Orinda, CA 94563

Description : Worm Tea

Project : Cal Poly SLO Masters Thesis
May 24, 2011

Lab ID : SP 1104701-003

Customer ID : 2-23787

Sampled On :

Sampled By : Payton Carling

Received On : May 12, 2011

Matrix : Non Potable Water

General Irrigation Suitability Analysis

\begin{tabular}{|c|c|c|c|c|c|c|c|c|c|}
\hline Test Description & & Result & & & & iraphica & esults Pre & entation & \\
\hline Cations & $\mathrm{mg} / \mathrm{L}$ & $\mathrm{Meq} / \mathrm{L}$ & $\% \mathrm{Meq}$ & $\mathrm{Lbs} / \mathrm{AF}$ & Good & $\begin{array}{l}\text { Possible } \\
\text { Problem }\end{array}$ & $\begin{array}{l}\text { Moderate } \\
\text { Problem }\end{array}$ & $\begin{array}{l}\text { Tincreasing } \\
\text { Problem }\end{array}$ & $\begin{array}{l}\text { Severe } \\
\text { Problem }\end{array}$ \\
\hline $\begin{array}{l}\text { Calcium } \\
\text { Magnesium } \\
\text { Potassium } \\
\text { Sodium }\end{array}$ & $\begin{array}{c}124 \\
123 \\
1960 \\
789\end{array}$ & $\begin{array}{c}6.2 \\
10 \\
50 \\
34 \\
\end{array}$ & $\begin{array}{c}6 \\
10 \\
50 \\
34\end{array}$ & $\begin{array}{c}340 \\
330 \\
5300 \\
2100\end{array}$ & $\begin{array}{l}* * \\
* * \\
* * 8\end{array}$ & & & & \\
\hline Anions & & & & & & & & & \\
\hline Carbonate & 60 & 2 & 2 & 160 & & & & & \\
\hline Bicarbonate & 3240 & 53 & 46 & 8800 & ** & & & & \\
\hline Sulfate & 300 & 6.2 & 5 & 820 & $* *$ & & & & \\
\hline Chloride & 1720 & 49 & 42 & 4700 & & & & & \\
\hline Nitrate & 270 & 4.4 & 4 & 730 & & & & & \\
\hline Fluoride & $<5$ & 0 & 0 & 0 & $\boldsymbol{Z}$ & & & & \\
\hline Minor Elements & & & & & & & & & \\
\hline Boron & 2.0 & & & 5.4 & & & & & \\
\hline Copper & 0.050 & & & 0.14 & $\beth$ & & & & \\
\hline & 0.68 & & & 1.8 & $\square$ & & & & \\
\hline Manganese & 0.50 & & & 1.4 & $\square$ & & & & \\
\hline Zinc & 0.22 & & & 0.60 & $\square$ & & & & \\
\hline TDS by Summation & 8590 & & & 23000 & & & & & \\
\hline $\begin{array}{l}\text { Other } \\
\mathrm{pH}\end{array}$ & 8.3 & & & units & & & & & \\
\hline E. C. & 11500 & & & umhos $/ \mathrm{cm}$ & & & & & \\
\hline SAR & 12.0 & & & & & & & & \\
\hline Crop Suitability & & & & & & & & & \\
\hline No Amendments & Poor & & & & & & & & \\
\hline With Amendments & Poor & & & & & & & & \\
\hline Amendments & & & & & & & & & \\
\hline Gypsum Requirement & 14.2 & & & Tons/AF & Do not & $y$ if $\mathrm{Sul}$ & ic Acid a & endment & applied. \\
\hline Sulfuric Acid (98\%) & 190 & & & $o z / 1000 \mathrm{Gal}$ & Or 470 & 1000Gal & urea Sulf & ric Acid & 5/49). \\
\hline Leaching Requirement & 460 & & & $\%$ & & & & & \\
\hline
\end{tabular}

Good Problem Indicales physical condicions and/or phenological and amendment requirements.

Note: Color coded bar graphs have been used to provide you with 'AT-A-GLANCE' interprecations.

853 Corporation Street

Canta Pon) $392-2006$

FAX: (805) 392-2063

Ornoe \& Laboratory

2500 otagecosch Roa

TEL: (209) 942-0182

FAX: (209) 942-0423
Omfloo \& Laboratory Chico, CA 95926

TEL: (530) 343-5818

FAX: (530) 343-3807

Omboe \& Laboratory Emprees Drive, Sulte D

ean Lula Oblspo, CA 93401

FAX: (805) 393-2940

Flold Otnoo

FAX: (559) 734-8435

Moblle: (559) 737-2399 
May 24, 2011

Lab ID : SP 1104701-003

Customer ID : 2-23787

Patty Frazer

Description : Worm Tea

Micro Irrigation System Plugging Hazard

\begin{tabular}{|c|c|c|c|c|c|}
\hline Test Description & & & & esults $\mathrm{Pr}$ & \\
\hline Chemical & & & Slight & Moderate & Severe \\
\hline Manganese & 0.5 & $\mathrm{mg} / \mathrm{L}$ & & 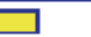 & \\
\hline Iron & 0.68 & $\mathrm{mg} / \mathrm{L}$ & & & \\
\hline TDS by Summation & 8590 & $\mathrm{mg} / \mathrm{L}$ & & & \\
\hline No Amendments & & & & & \\
\hline & 8.3 & units & & & \\
\hline Alkalinity & 2750 & $\mathrm{mg} / \mathrm{L}$ & & & \\
\hline Total Hardness & 815 & $\mathrm{mg} / \mathrm{L}$ & & & \\
\hline With Amendments & & & & & \\
\hline Alkalinity & 550 & $\mathrm{mg} / \mathrm{L}$ & & & \\
\hline Total Hardness & 550 & $\mathrm{mg} / \mathrm{L}$ & & & \\
\hline $\mathrm{pH}$ & $5.4-6.7$ & units & & & \\
\hline
\end{tabular}

Good $\quad$ Problem Indicates physical condicions and/or phenological and amendment requirements.

Nowe: Color coded bar graphs have been used to provide you with 'AT-A-GLANCE' interpertations.

Water Amendments Application Notes:

The Amendments recommended on the previous pages include:

Gypsum:

This should be applied at least once a year to the irrigated soil surface area. Gypsum can also be applied in smaller quantities in the irrigation water. Apply the smaller (bracketed) amount of gypsum when also applying the recommended amount of Sulfuric Acid and the larger amount when applying only Gypsum.

Sulfuric Acid:

These products should be applied as needed to prevent emitter plugging in micro irrigation systems and/or as a soil amendment to adjust soil $\mathrm{pH}$ to improve nutrient availability and to facilitate leaching of salts. Please exercise caution when using this material as excesses may be harmful to the system and/or the plants being irrigated.

The reported Acid requirement is intended to remove approximately $80 \%$ of the alkalinity. The final pH should range from 5.4 to 6.7 . We recommend a field $\mathrm{pH}$ determination to confirm that the $\mathrm{pH}$ you designate is being achieved. This application is based upon the use of a $98 \%$ Sulfuric Acid product. The application of Urea Sulfuric Acid is based upon the use of a product that contains $15 \%$ Urea (1.89 Ibs Nitrogen), $49 \%$ Sulfuric Acid and has a specific gravity of 1.52 at $68{ }^{\circ} \mathrm{F}$.

Guidelines for the above interpretations are sourced from USDA \& U.C. Cooperative Extension Service publications. Please contact us if you have any questions.

CEL:EHB

FRUIT GROWERS LABORATORY, INC.

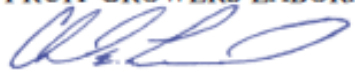

Chad Lessard, Director of Ag. Services 


\section{APPENDIX B}

Statistical Analysis of Fruit Yield and Tree Size

Page 74 
$\checkmark$ Oneway Analysis of fruit kilos By treatment

$\checkmark$ Oneway Anova

$\checkmark$ Summary of Fit

Rsquare

0.491285

Adj Rsquare

0.436779

Root Mean Square Error

4.559868

Mean of Response

5.658438

Observations (or Sum Wgts)

32

$\checkmark$ Analysis of Variance

\begin{tabular}{lrrrrr} 
& \multicolumn{1}{c}{ Sum of } & & & \\
Source & DF & Squares & Mean Square & F Ratio & Prob > F \\
treatment & 3 & 562.2386 & 187.413 & 9.0135 & $0.0002^{*}$ \\
Error & 28 & 582.1870 & 20.792 & & \\
C. Total & 31 & 1144.4256 & & &
\end{tabular}

$\checkmark$ Means for Oneway Anova

$\begin{array}{lrrrrr}\text { Level } & \text { Number } & \text { Mean } & \text { Std Error } & \text { Lower 95\% } & \text { Upper 95\% } \\ \text { con } & 8 & 3.8625 & 1.6122 & 0.560 & 7.165 \\ \text { cvtf } & 8 & 12.8750 & 1.6122 & 9.573 & 16.177 \\ \text { gmcc } & 8 & 3.3250 & 1.6122 & 0.023 & 6.627 \\ \text { vtf } & 8 & 2.5713 & 1.6122 & -0.731 & 5.874\end{array}$

Std Error uses a pooled estimate of error variance 
- Oneway Analysis of fruit kilos By treatment

$\checkmark$ Oneway Anova

v Summary of Fit

ivur inuir syuurc Liru

Mean of Response

T..八นกט

Observations (or Sum Wgts)

32

Analysis of Variance

$\begin{array}{lrrrrr}\text { Source } & \text { DF } & \begin{array}{r}\text { Sum of } \\ \text { Squares }\end{array} & \text { Mean Square } & \text { F Ratio } & \text { Prob > F } \\ \text { treatment } & 3 & 562.2386 & 187.413 & 9.0135 & 0.0002^{*} \\ \text { Error } & 28 & 582.1870 & 20.792 & & \\ \text { C. Total } & 31 & 1144.4256 & & & \end{array}$

$\checkmark$ Means for Oneway Anova

$\begin{array}{lrrrrr}\text { Level } & \text { Number } & \text { Mean } & \text { Std Error } & \text { Lower 95\% } & \text { Upper 95\% } \\ \text { con } & 8 & 3.8625 & 1.6122 & 0.560 & 7.165 \\ \text { cvtf } & 8 & 12.8750 & 1.6122 & 9.573 & 16.177 \\ \text { gmcc } & 8 & 3.3250 & 1.6122 & 0.023 & 6.627 \\ \text { vtf } & 8 & 2.5713 & 1.6122 & -0.731 & 5.874\end{array}$

Std Error uses a pooled estimate of error variance

Means Comparisons

$\checkmark$ Comparisons for all pairs using Tukey-Kramer HSD

$q^{*} \quad$ Alpha

$2.73031 \quad 0.05$

Abs(Dif)-HSD

$\begin{array}{lrrrr} & \text { cvtf } & \text { con } & \text { gmcc } & \text { vtf } \\ \text { cvtf } & -6.2249 & 2.7876 & 3.3251 & 4.0788 \\ \text { con } & 2.7876 & -6.2249 & -5.6874 & -4.9337 \\ \text { gmcc } & 3.3251 & -5.6874 & -6.2249 & -5.4712 \\ \text { vtf } & 4.0788 & -4.9337 & -5.4712 & -6.2249\end{array}$

Positive values show pairs of means that are significantly different.

$\begin{array}{lrr}\text { Level } & & \text { Mean } \\ \text { cvtf } & \text { A } & 12.875000 \\ \text { con } & \text { B } & 3.862500 \\ \text { gmcc } & \text { B } & 3.325000 \\ \text { vtf } & \text { B } & 2.571250\end{array}$

Levels not connected by same letter are significantly different.

$\begin{array}{llrrrrl}\text { Level } & \text { - Level } & \text { Difference } & \text { Std Err Dif } & \text { Lower CL } & \text { Upper CL } & \text { p-Value } \\ \text { cvtf } & \text { vtf } & 10.30375 & 2.279934 & 4.07882 & 16.52868 & 0.0006^{*} \\ \text { cvtf } & \text { gmcc } & 9.55000 & 2.279934 & 3.32507 & 15.77493 & 0.0014^{*} \\ \text { cvtf } & \text { con } & 9.01250 & 2.279934 & 2.78757 & 15.23743 & 0.0025^{*} \\ \text { con } & \text { vtf } & 1.29125 & 2.279934 & -4.93368 & 7.51618 & 0.9412 \\ \text { gmcc } & \text { vtf } & 0.75375 & 2.279934 & -5.47118 & 6.97868 & 0.9873 \\ \text { con } & \text { gmcc } & 0.53750 & 2.279934 & -5.68743 & 6.76243 & 0.9953\end{array}$


Oneway Analysis of fruit \# By treatment

Oneway Anova

$\nabla$ Summary of Fit

Rsquare

0.485536

Adj Rsquare

0.430415

Root Mean Square Error $\quad 31.08234$

Mean of Response 36.65625

Observations (or Sum Wgts)

32

$\checkmark$ Analysis of Variance

$\begin{array}{lrrrrr}\text { Source } & \text { DF } & \begin{array}{r}\text { Sum of } \\ \text { Squares }\end{array} & \text { Mean Square } & \text { F Ratio } & \text { Prob > F } \\ \text { treatment } & 3 & 25530.094 & 8510.03 & 8.8085 & 0.0003^{*} \\ \text { Error } & 28 & 27051.125 & 966.11 & & \\ \text { C. Total } & 31 & 52581.219 & & & \end{array}$

$\checkmark$ Means for Oneway Anova

$\begin{array}{lrrrrr}\text { Level } & \text { Number } & \text { Mean } & \text { Std Error } & \text { Lower 95\% } & \text { Upper 95\% } \\ \text { con } & 8 & 23.3750 & 10.989 & 0.86 & 45.89 \\ \text { cvtf } & 8 & 85.2500 & 10.989 & 62.74 & 107.76 \\ \text { gmcc } & 8 & 22.8750 & 10.989 & 0.36 & 45.39 \\ \text { vtf } & 8 & 15.1250 & 10.989 & -7.39 & 37.64\end{array}$

Std Error uses a pooled estimate of error variance 
- Oneway Analysis of fruit \# By treatment

$\checkmark$ Oneway Anova

$\checkmark$ Summary of Fit Mean of Response 36.65625

Observations (or Sum Wgts)

32

$\checkmark$ Analysis of Variance

\begin{tabular}{lrrrrr} 
& \multicolumn{1}{c}{ Sum of } & & & \\
Source & DF & $\begin{array}{r}\text { Squares } \\
\text { treatment }\end{array}$ & Mean Square & F Ratio & Prob > F \\
Error & 25530.094 & 8510.03 & 8.8085 & $0.0003^{*}$ \\
C. Total & 31 & 27051.125 & 966.11 & &
\end{tabular}

$\checkmark$ Means for Oneway Anova

$\begin{array}{lrrrrr}\text { Level } & \text { Number } & \text { Mean } & \text { Std Error } & \text { Lower 95\% } & \text { Upper 95\% } \\ \text { con } & 8 & 23.3750 & 10.989 & 0.86 & 45.89 \\ \text { cvtf } & 8 & 85.2500 & 10.989 & 62.74 & 107.76 \\ \text { gmcc } & 8 & 22.8750 & 10.989 & 0.36 & 45.39 \\ \text { vtf } & 8 & 15.1250 & 10.989 & -7.39 & 37.64\end{array}$

Std Error uses a pooled estimate of error variance

$\checkmark$ Means Comparisons

$\checkmark$ Comparisons for all pairs using Tukey-Kramer HSD

$$
q^{*} \quad \text { Alpha }
$$

$2.73031 \quad 0.05$

Abs(Dif)-HSD

$\begin{array}{lrrrr} & \text { cvtf } & \text { con } & \text { gmcc } & \text { vtf } \\ \text { cvtf } & -42.432 & 19.443 & 19.943 & 27.693 \\ \text { con } & 19.443 & -42.432 & -41.932 & -34.182 \\ \text { gmcc } & 19.943 & -41.932 & -42.432 & -34.682 \\ \text { vtf } & 27.693 & -34.182 & -34.682 & -42.432\end{array}$

Positive values show pairs of means that are significantly different.

$\begin{array}{lrrr}\text { Level } & & \text { Mean } \\ \text { cvtf } & \text { A } & 85.250000 \\ \text { con } & \text { B } & 23.375000 \\ \text { gmcc } & \text { B } & 22.875000 \\ \text { vtf } & \text { B } & 15.125000\end{array}$

Levels not connected by same letter are significantly different.

$\begin{array}{llrrrrl}\text { Level } & \text { - Level } & \text { Difference } & \text { Std Err Dif } & \text { Lower CL } & \text { Upper CL } & \text { p-Value } \\ \text { cvtf } & \text { vtf } & 70.12500 & 15.54117 & 27.6928 & 112.5572 & 0.0006^{*} \\ \text { cvtf } & \text { gmcc } & 62.37500 & 15.54117 & 19.9428 & 104.8072 & 0.0022^{*} \\ \text { cvtf } & \text { con } & 61.87500 & 15.54117 & 19.4428 & 104.3072 & 0.0024^{*} \\ \text { con } & \text { vtf } & 8.25000 & 15.54117 & -34.1822 & 50.6822 & 0.9508 \\ \text { gmcc } & \text { vtf } & 7.75000 & 15.54117 & -34.6822 & 50.1822 & 0.9587 \\ \text { con gmcc } & 0.50000 & 15.54117 & -41.9322 & 42.9322 & 1.0000\end{array}$


- Oneway Analysis of Size By treatment

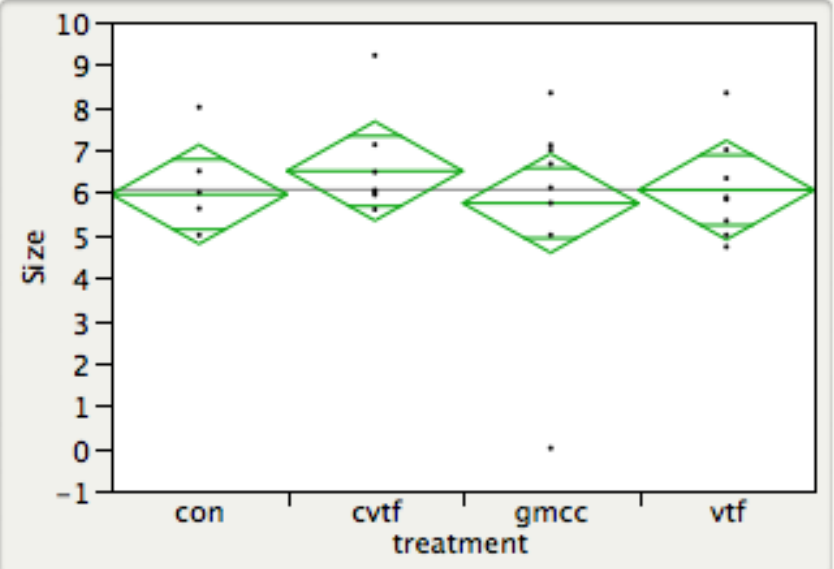

- Oneway Anova

$\checkmark$ Summary of Fit

Rsquare

0.032668

Adj Rsquare

$-0.07097$

1.604555

Root Mean Square Error

6.063899

Mean of Response

32

$\checkmark$ Analysis of Variance

$\begin{array}{lrrrrr}\text { Source } & \text { DF } & \begin{array}{r}\text { Sum of } \\ \text { Squares }\end{array} & \text { Mean Square } & \text { F Ratio } & \text { Prob > F } \\ \text { treatment } & 3 & 2.434511 & 0.81150 & 0.3152 & 0.8142 \\ \text { Error } & 28 & 72.088717 & 2.57460 & & \\ \text { C. Total } & 31 & 74.523228 & & & \end{array}$

$\checkmark$ Means for Oneway Anova

$\begin{array}{lrrrrr}\text { Level } & \text { Number } & \text { Mean } & \text { Std Error } & \text { Lower 95\% } & \text { Upper 95\% } \\ \text { con } & 8 & 5.95313 & 0.56730 & 4.7911 & 7.1152 \\ \text { cvtf } & 8 & 6.50120 & 0.56730 & 5.3391 & 7.6633 \\ \text { gmcc } & 8 & 5.74653 & 0.56730 & 4.5845 & 6.9086 \\ \text { vtf } & 8 & 6.05474 & 0.56730 & 4.8927 & 7.2168\end{array}$

Std Error uses a pooled estimate of error variance 
- Oneway Analysis of tree height By treatment

$\checkmark$ Oneway Anova

$\checkmark$ Summary of Fit Rsquare 0.068528

Adj Rsquare

$-0.03127$

Root Mean Square Error $\quad 0.594143$

Mean of Response 2.55625

Observations (or Sum Wgts)

32

$\checkmark$ Analysis of Variance

$\begin{array}{lrrrrr}\text { Source } & \text { DF } & \begin{array}{r}\text { Sum of } \\ \text { Squares }\end{array} & \text { Mean Square } & \text { F Ratio } & \text { Prob > F } \\ \text { treatment } & 3 & 0.727175 & 0.242392 & 0.6866 & 0.5678 \\ \text { Error } & 28 & 9.884175 & 0.353006 & & \\ \text { C. Total } & 31 & 10.611350 & & & \end{array}$

\section{$\checkmark$ Means for Oneway Anova}

$\begin{array}{lrrrrr}\text { Level } & \text { Number } & \text { Mean } & \text { Std Error } & \text { Lower 95\% } & \text { Upper 95\% } \\ \text { con } & 8 & 2.58500 & 0.21006 & 2.1547 & 3.0153 \\ \text { cvtf } & 8 & 2.78000 & 0.21006 & 2.3497 & 3.2103 \\ \text { gmcc } & 8 & 2.49375 & 0.21006 & 2.0635 & 2.9240 \\ \text { vtf } & 8 & 2.36625 & 0.21006 & 1.9360 & 2.7965\end{array}$

Std Error uses a pooled estimate of error variance

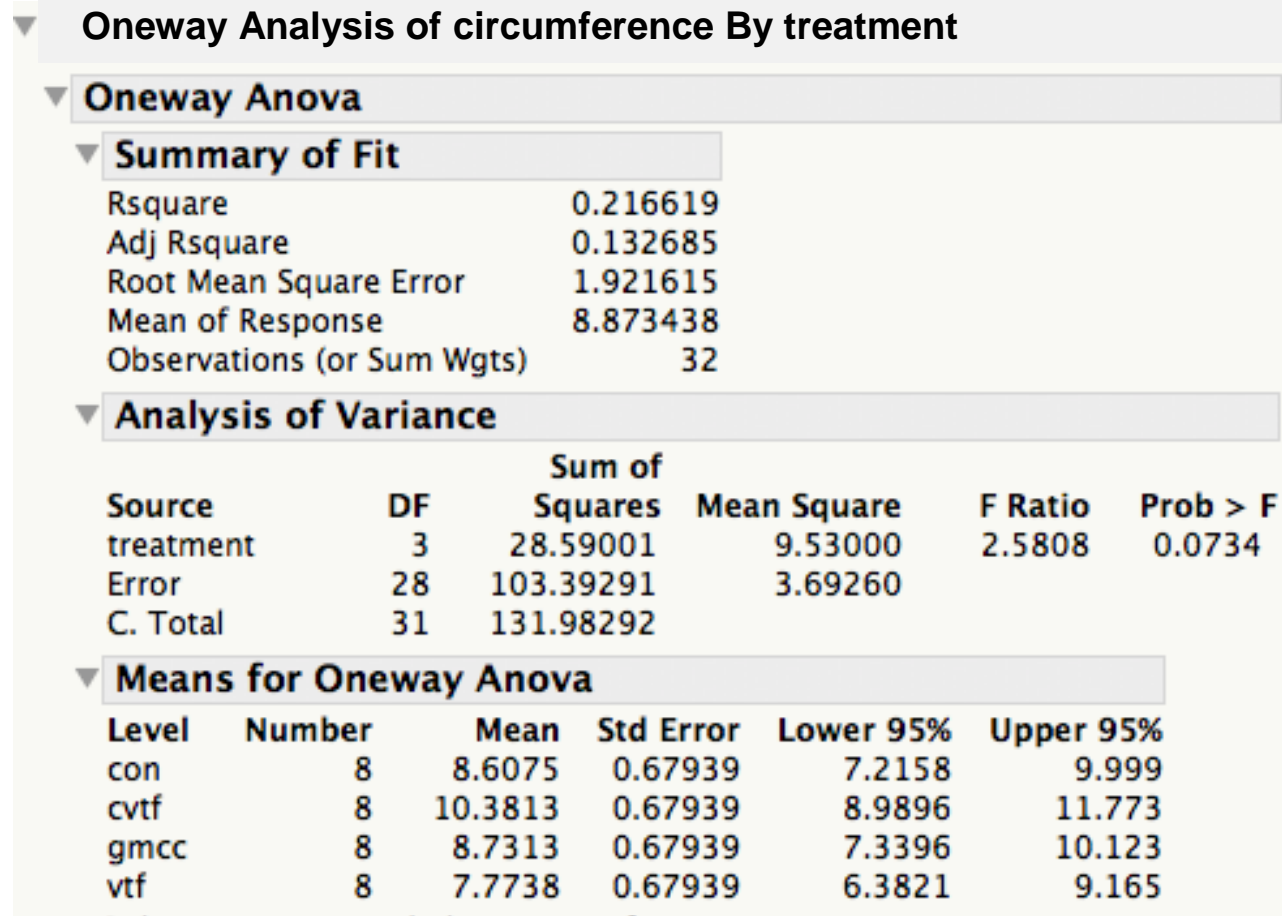

Std Error uses a pooled estimate of error variance 
APPENDIX C

\section{Photo Essay of the Experiment}

\section{Experimental Site}

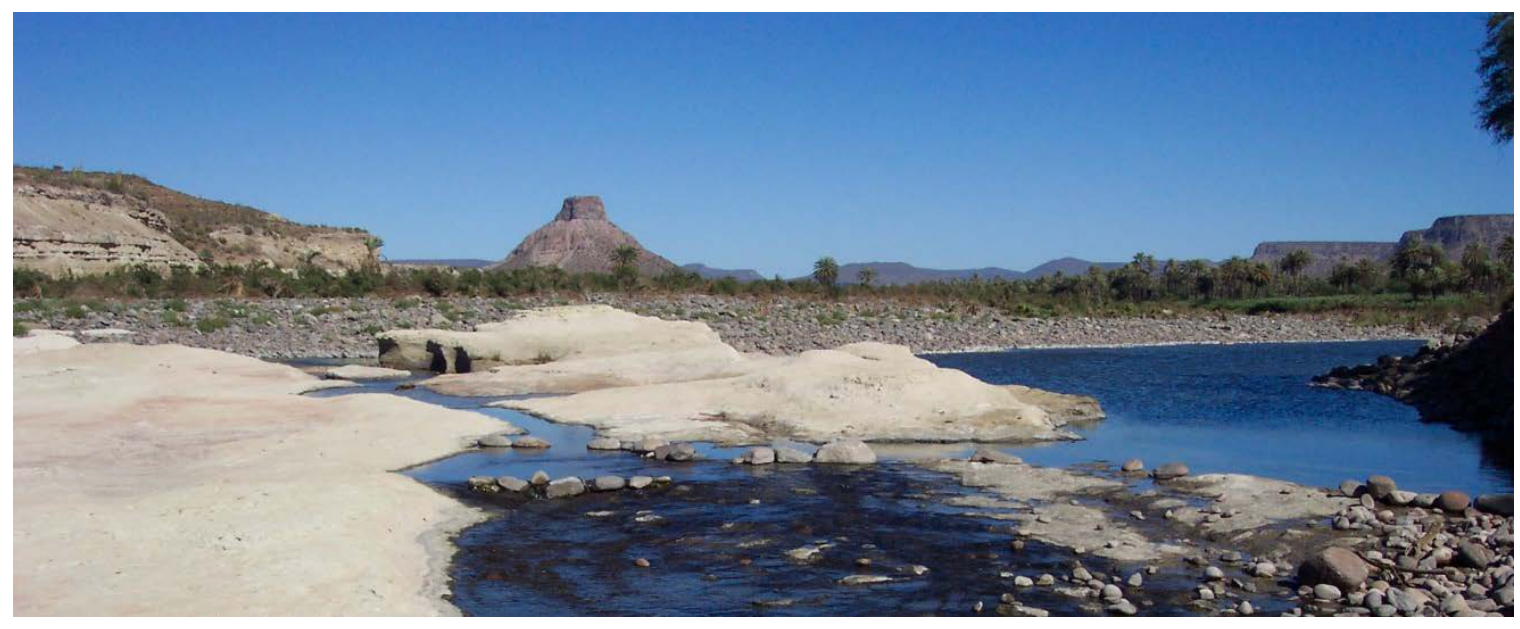

The Cadegomo Oasis Valley, San Isidro, Baja California Sur, Mexico

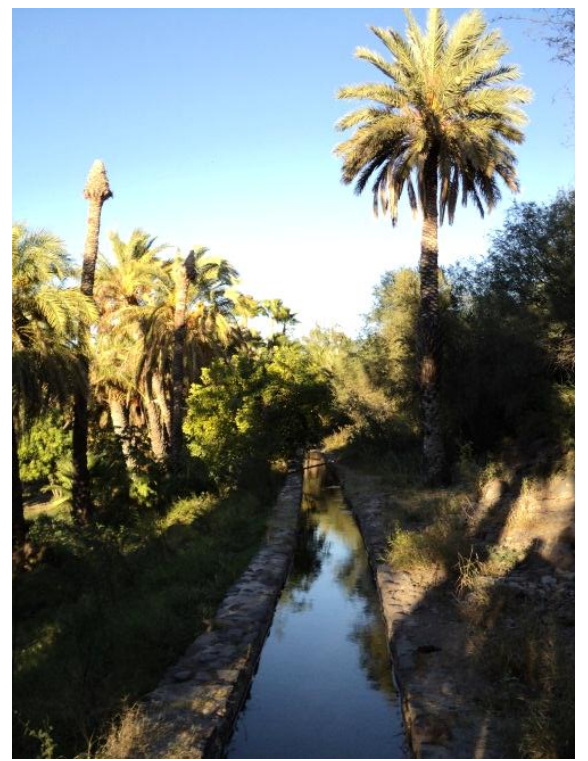

San Isidro Irrigation Canal

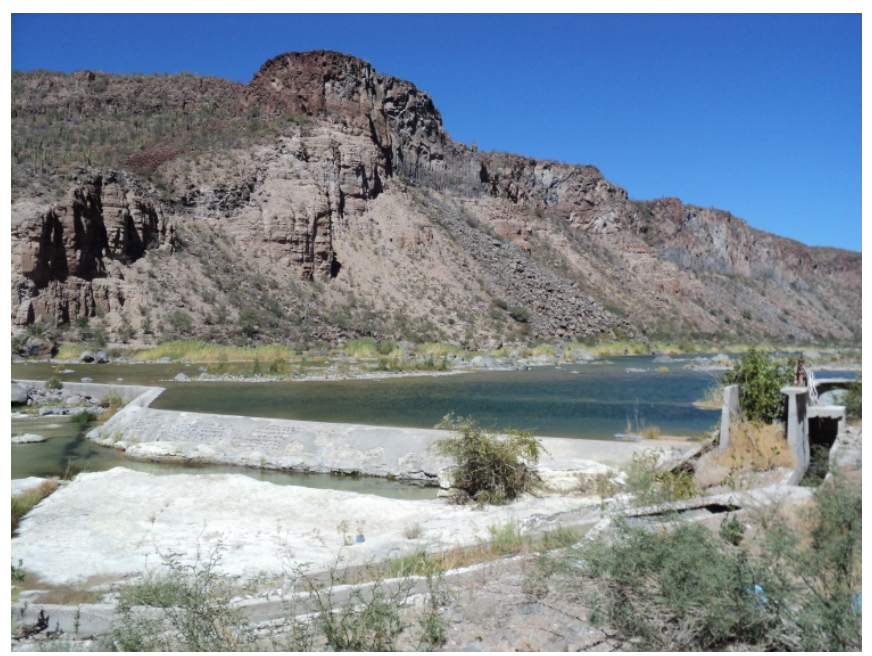

San Isidro Irrigation Dam 


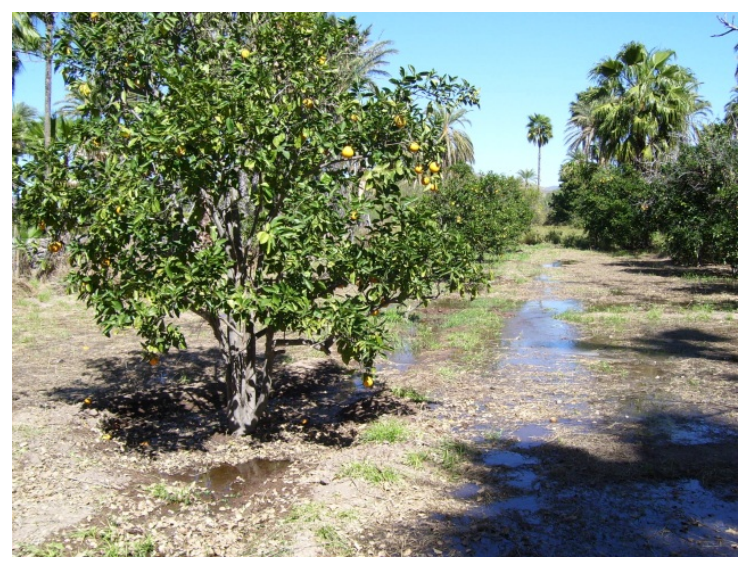

Irrigating the WNO Experimental Orchard

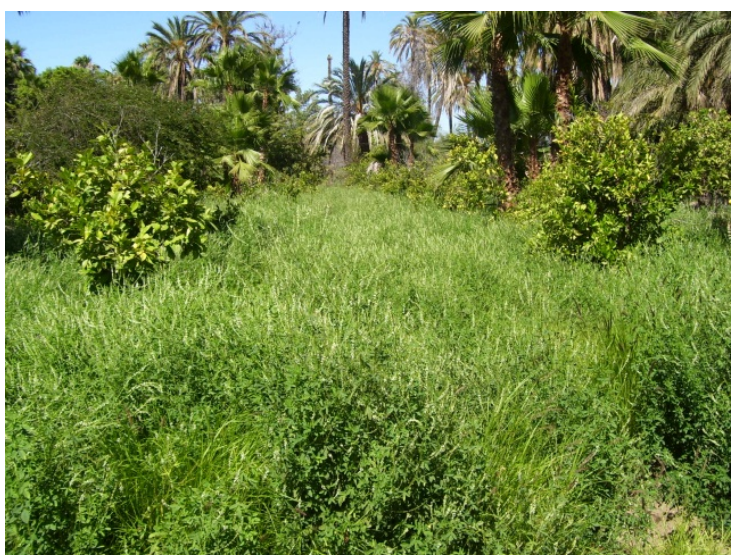

Sweet Clovers Growing in the Alley of the WNO Experimental Orchard

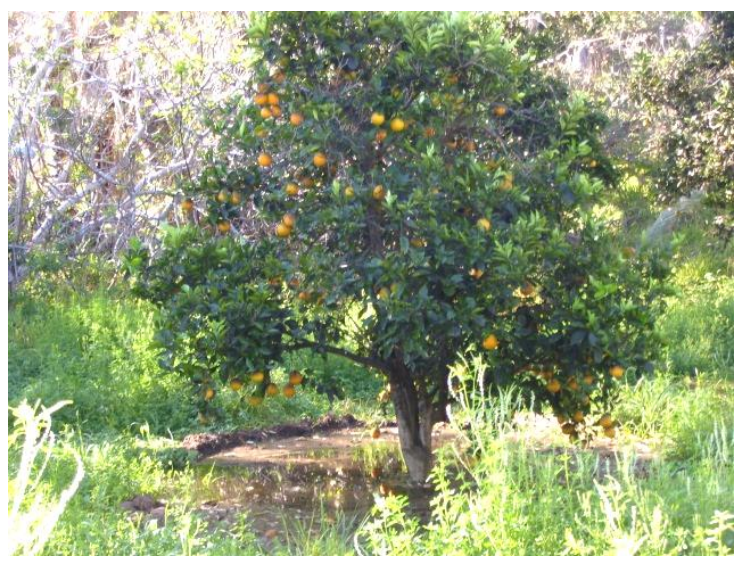

C+VEF Treatment WNO Under Irrigation

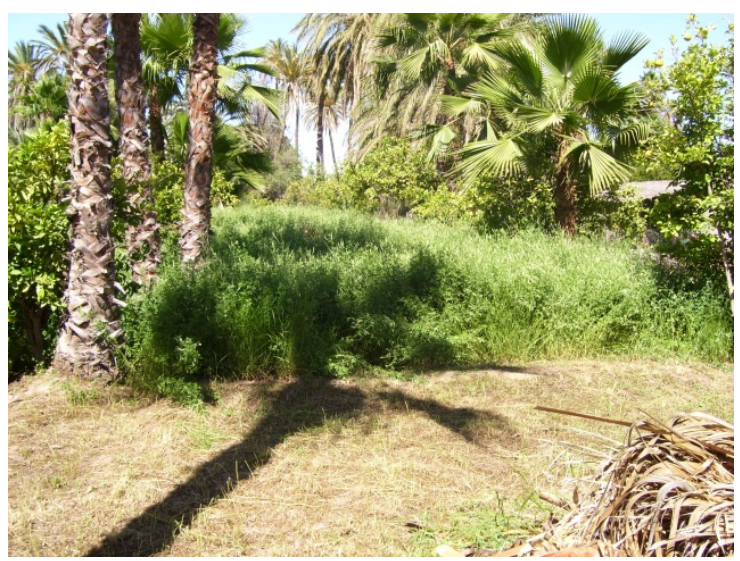

Sweet Clover Partially Cut for Livestock Feed 


\section{Compost}

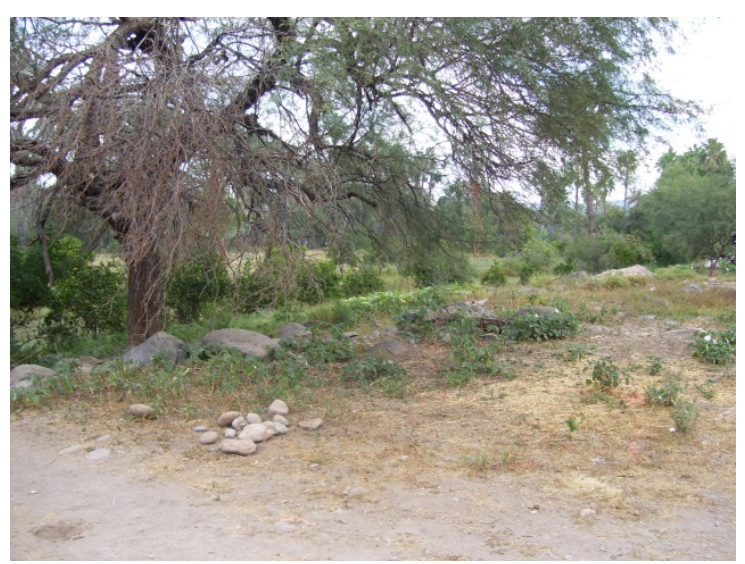

Compost Site Before Construction

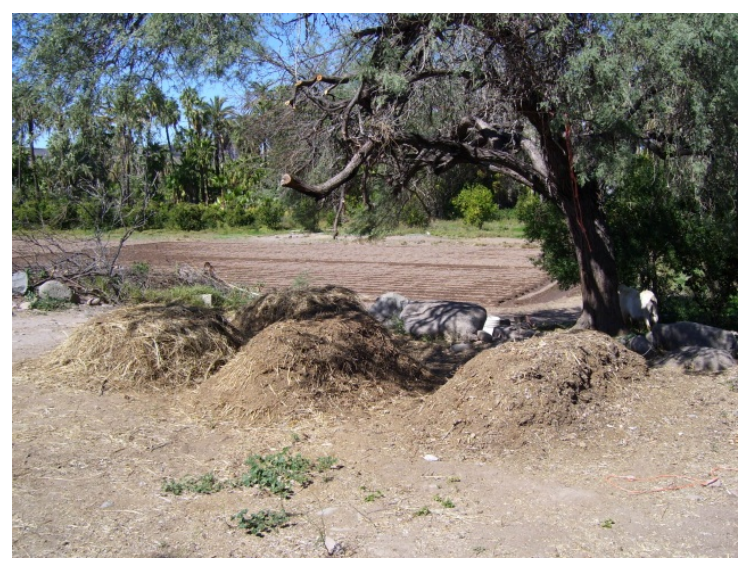

Finished Compost Pile, Compost Pile Turned Once and Recently Constructed Piles

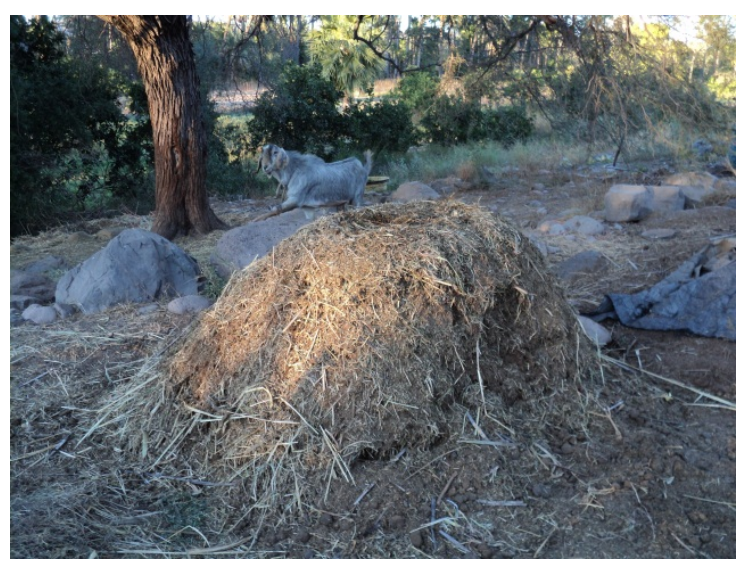

Completed Compost Pile

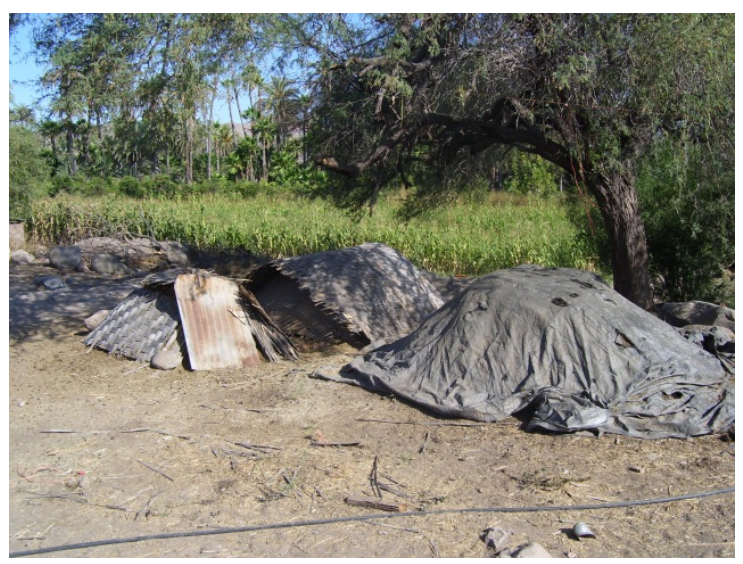

All Compost Covered to Retain Moisture 


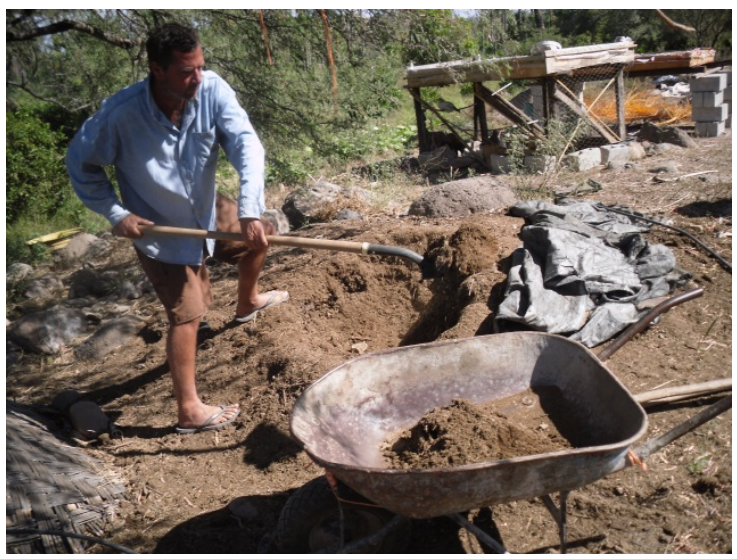

Shoveling Compost for WNO Tree Application

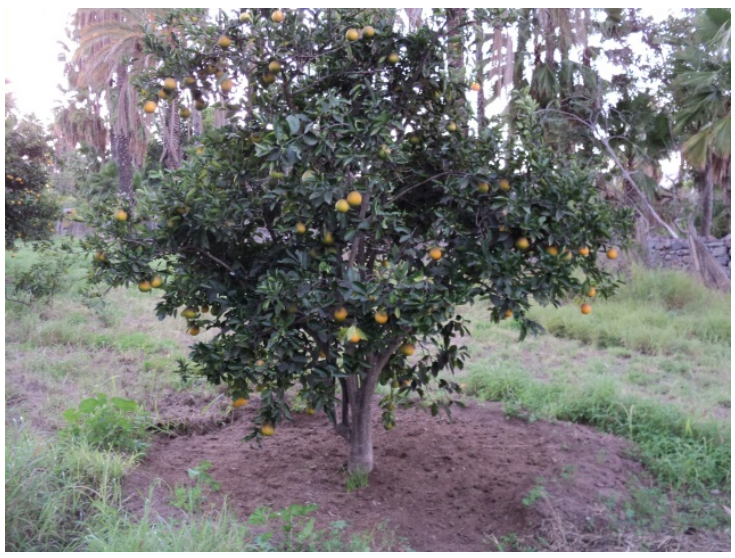

Compost Applied Under WNO Tree

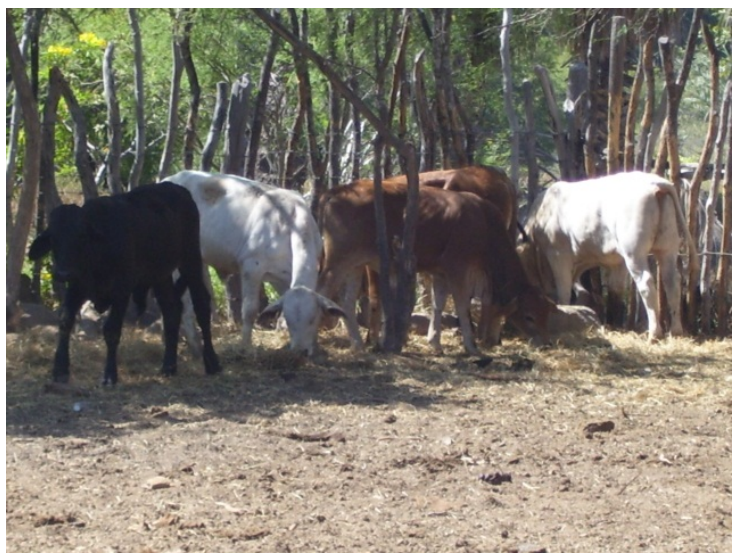

Cows in the Corral Contributed Manure for the Compost

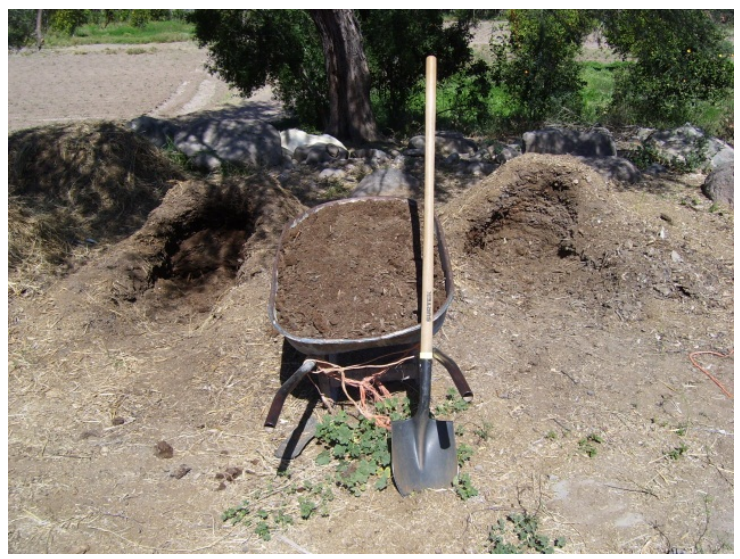

Full Wheelbarrow Taken from Finished Compost Piles

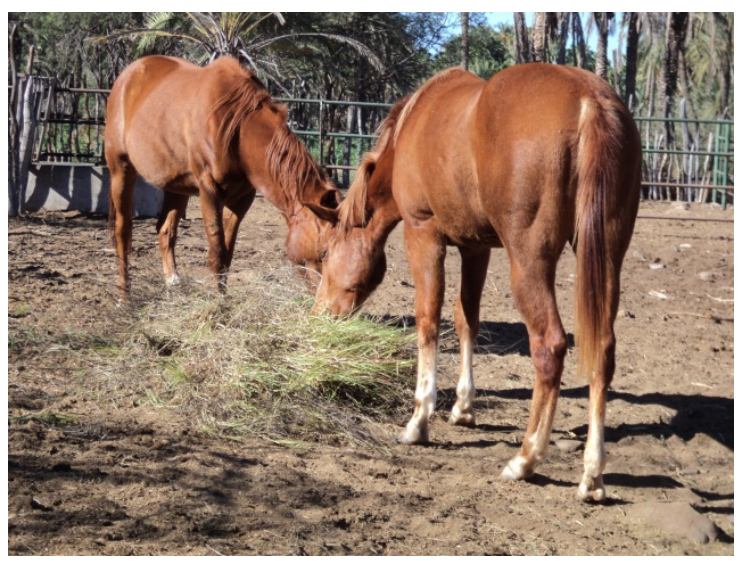

The Farm Horses Contributed Manure for Compost

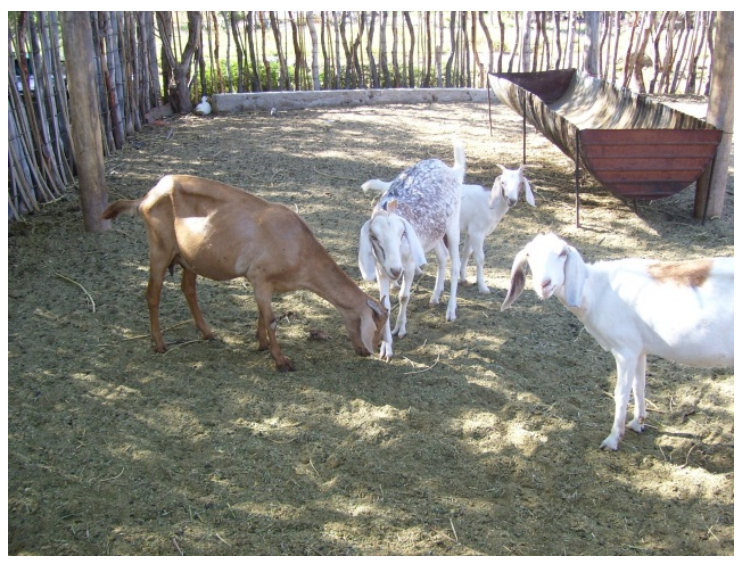

Milking Goats on the Farm Contributed Manure for the Compost 


\section{Legume Cover Crop}

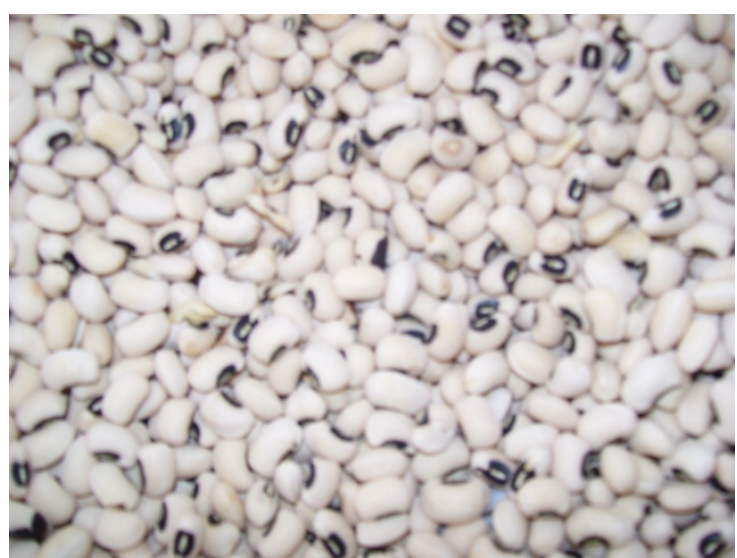

Black-Eyed Pea Seeds

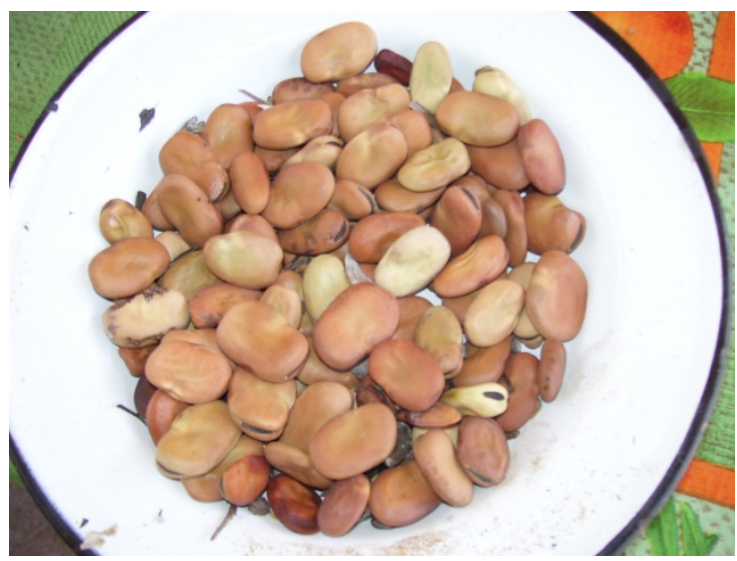

Faba Bean Seeds

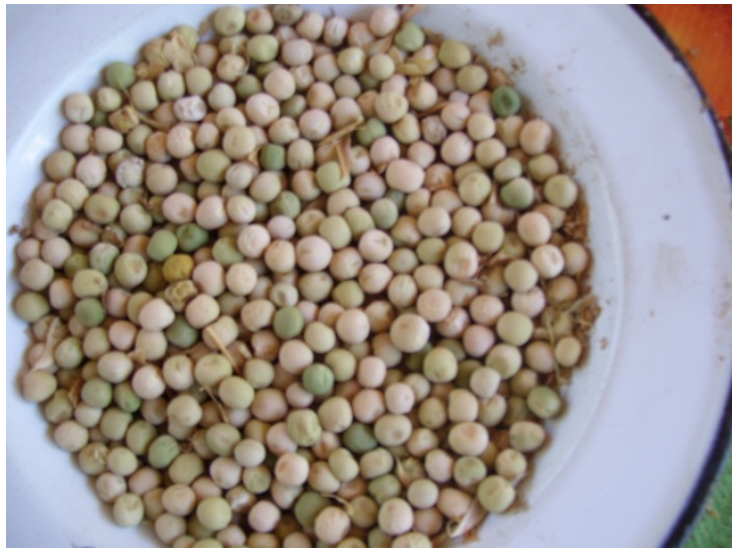

Dry Pea Seeds

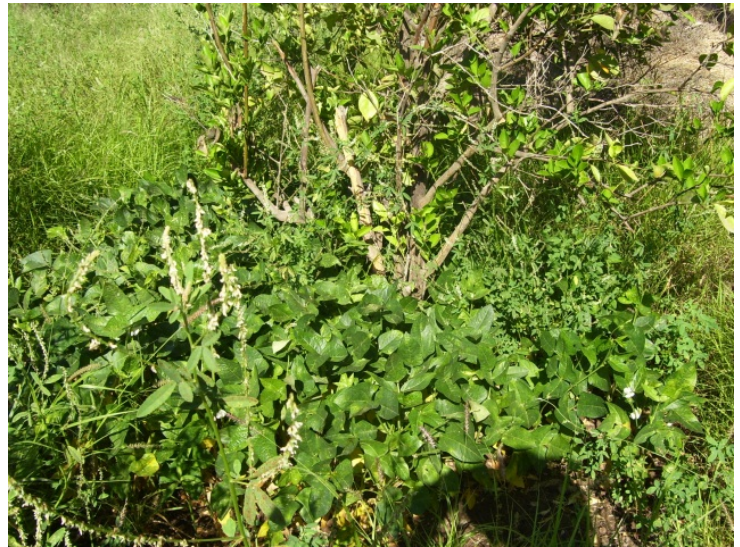

Black-Eyed Peas Growing Under WNO Tree

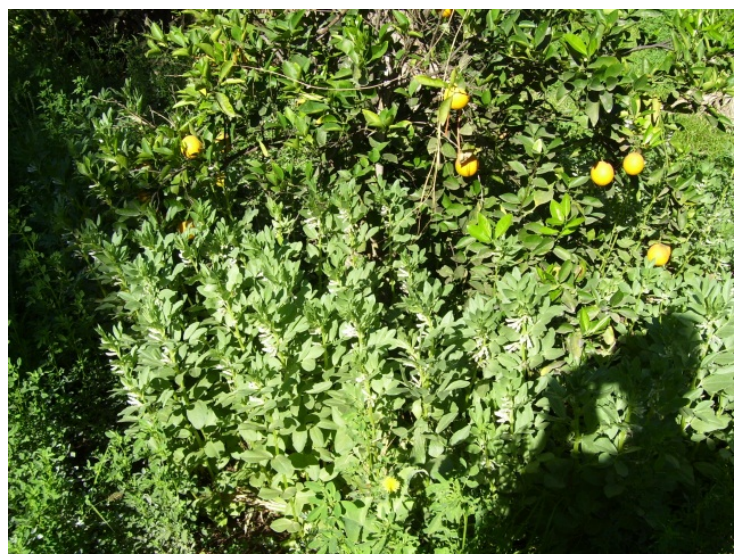

Faba Beans Growing Under WNO Tree

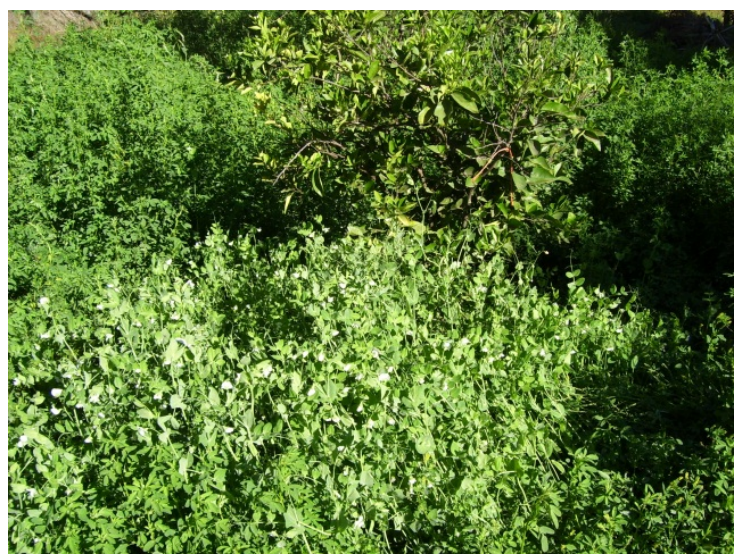

Dry Peas Growing Under WNO Tree 


\section{Vermicompost Extract Foliar}

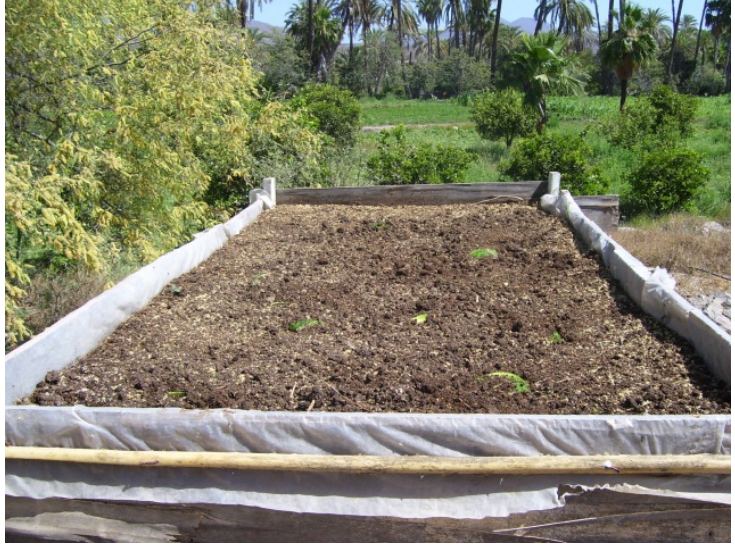

Vermicompost Table 1

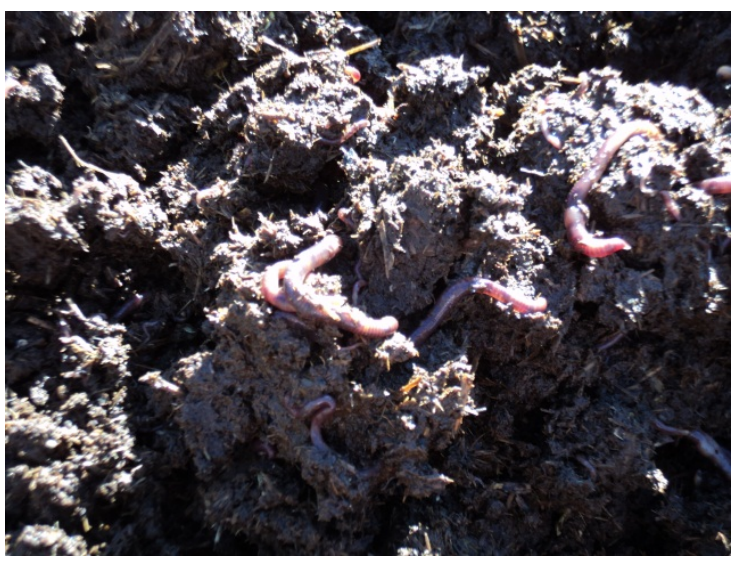

Red Wiggler Worms (Eisenia fetida)

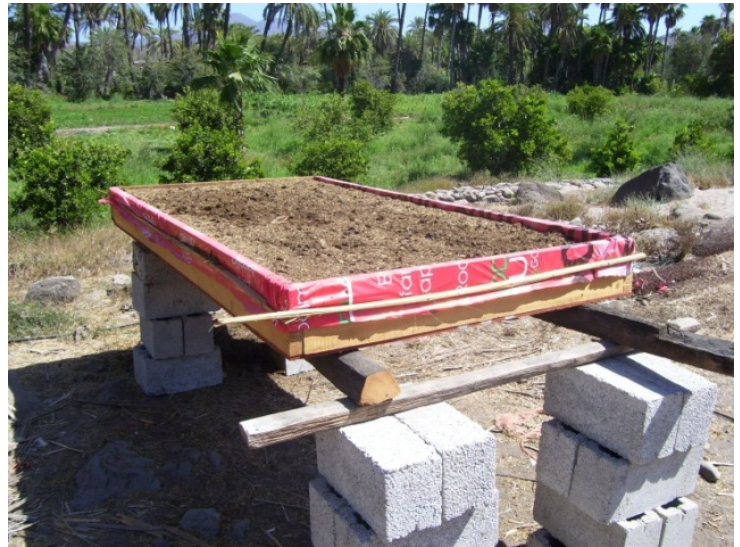

Vermicompost Table 2

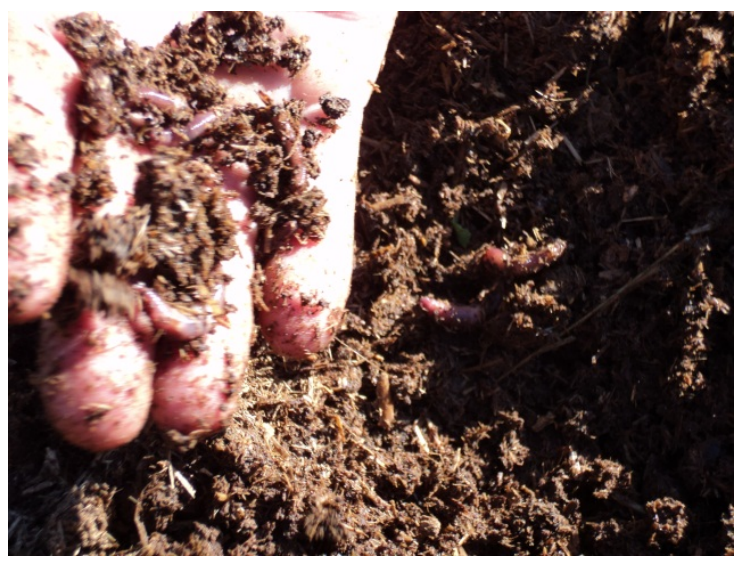

Red Wiggler Worms (Eisenia fetida) 

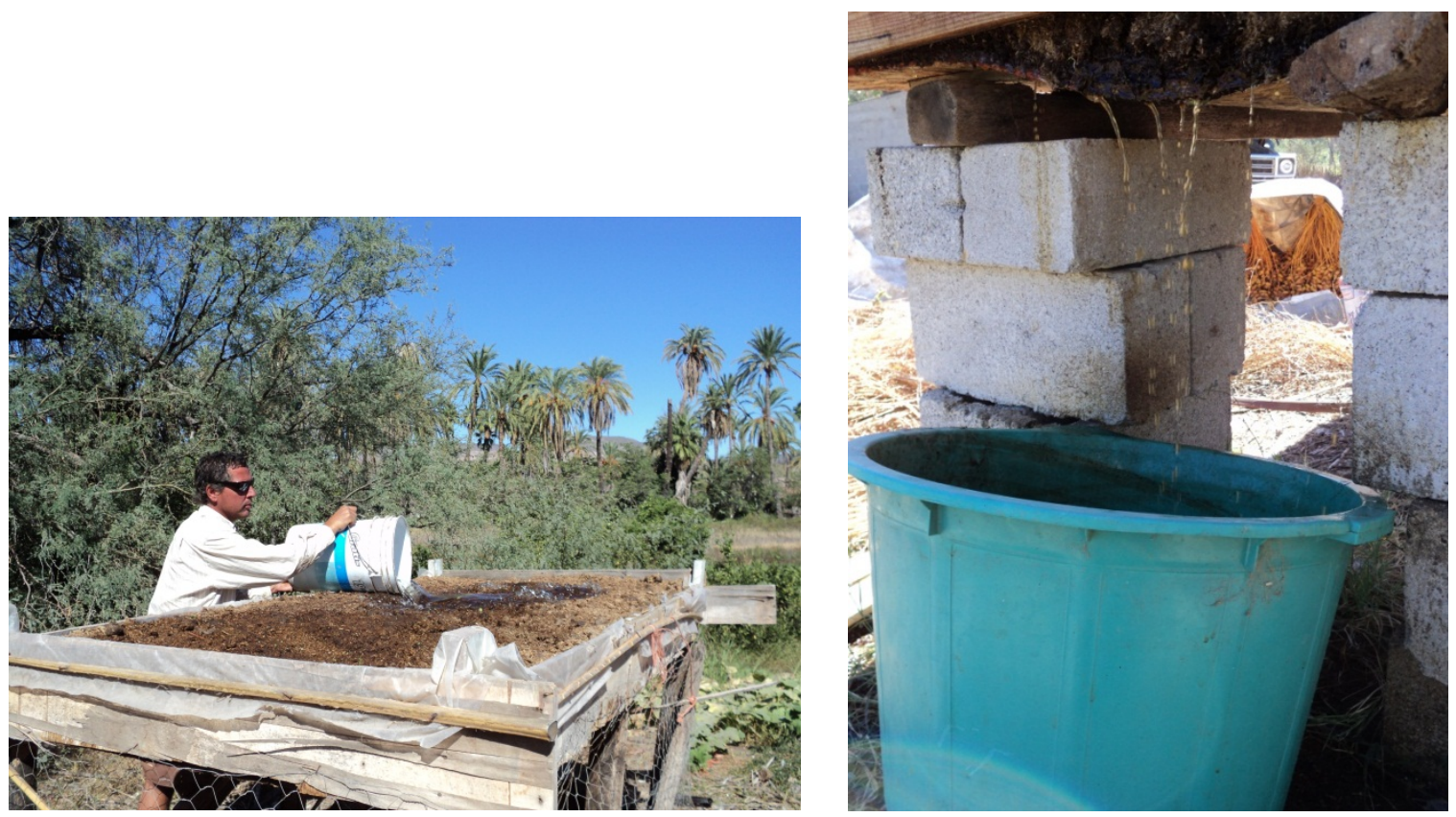

Applying Water to Vermicompost Table 1

Vermicompost Extract Being Collected in Bucket

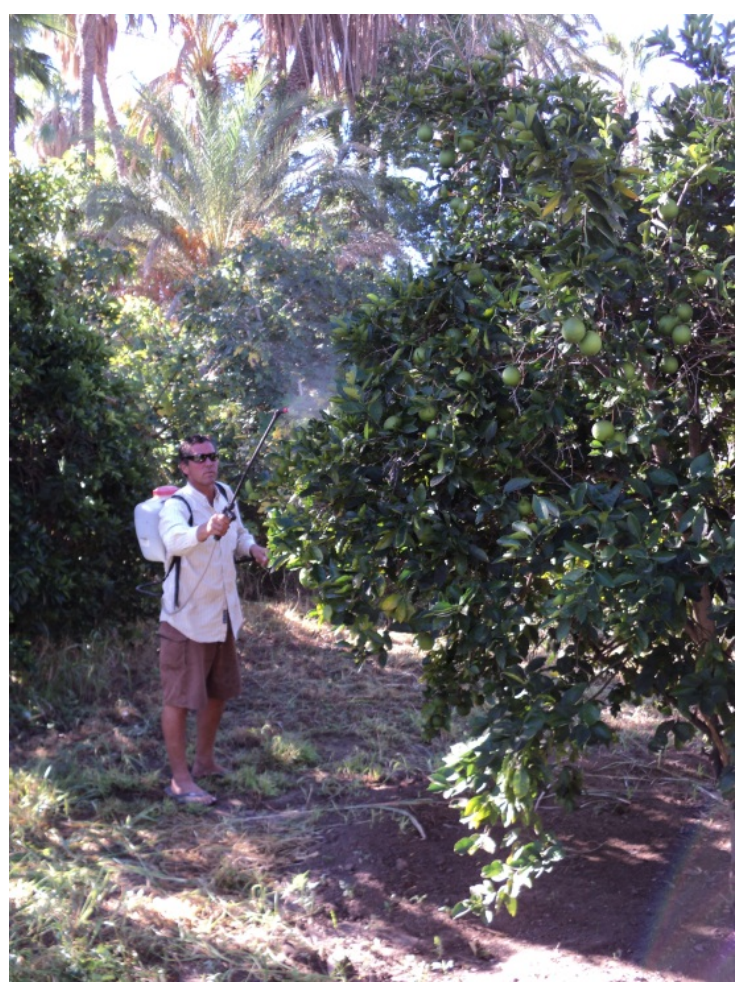

Fine Spraying Vermicompost Extract on WNO Tree Upper Foliage

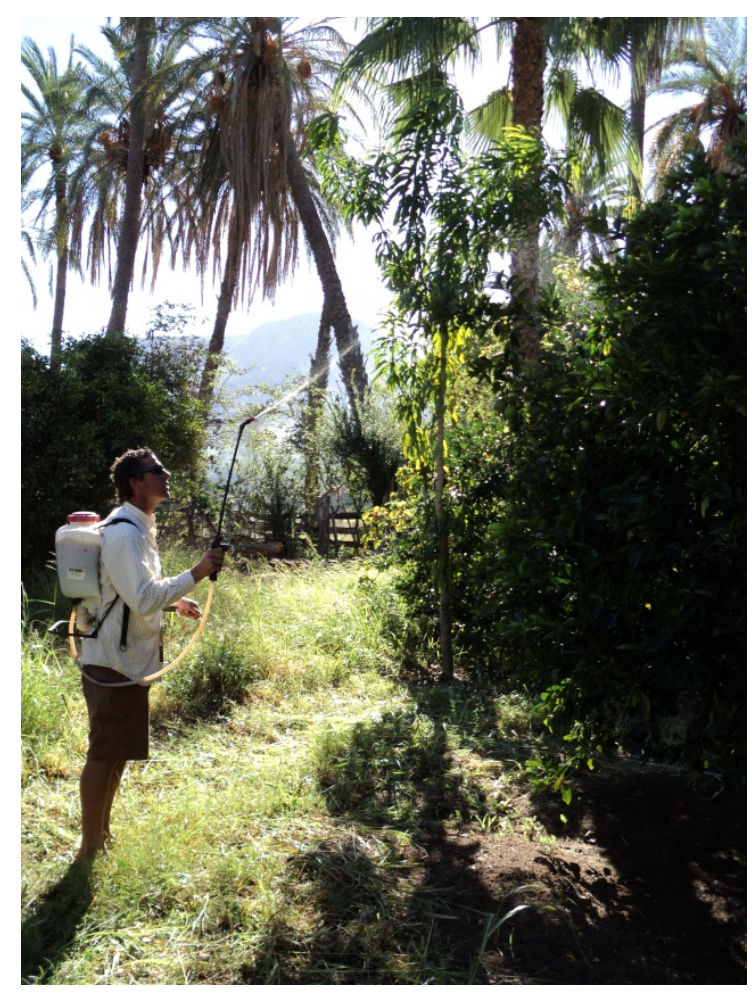

Stream Spraying Vermicompost Extract on WNO Tree Upper Foliage 
Washington Navel Orange Trees in Experiment

Compost and Vermicompost Extract Foliar

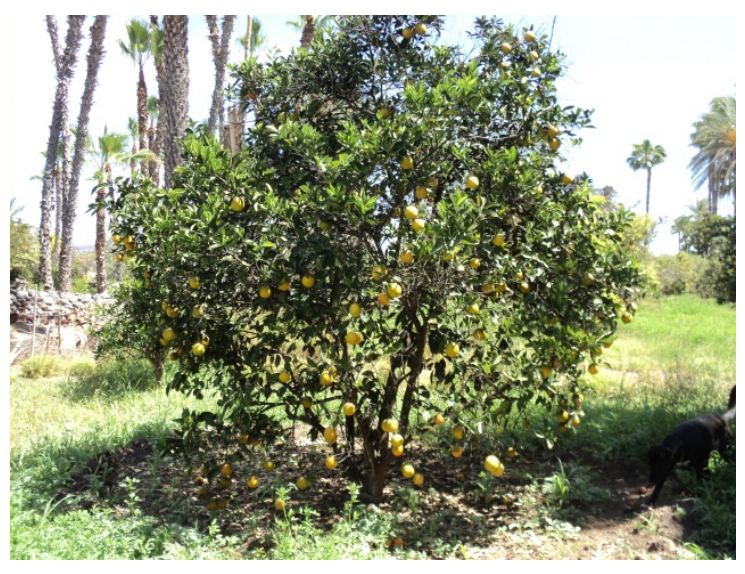

$\mathrm{C}+\mathrm{VEF} 1$

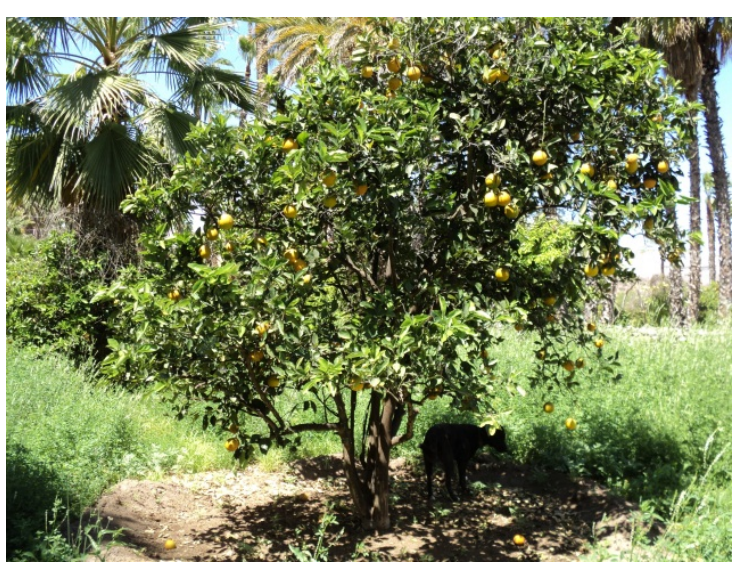

$\mathrm{C}+\mathrm{VEF} 2$

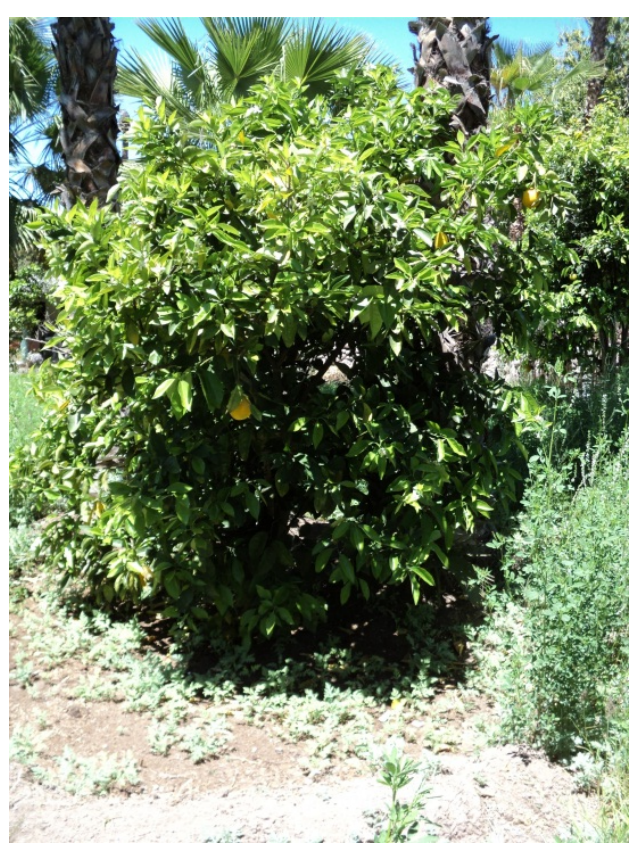

C+VEF 3

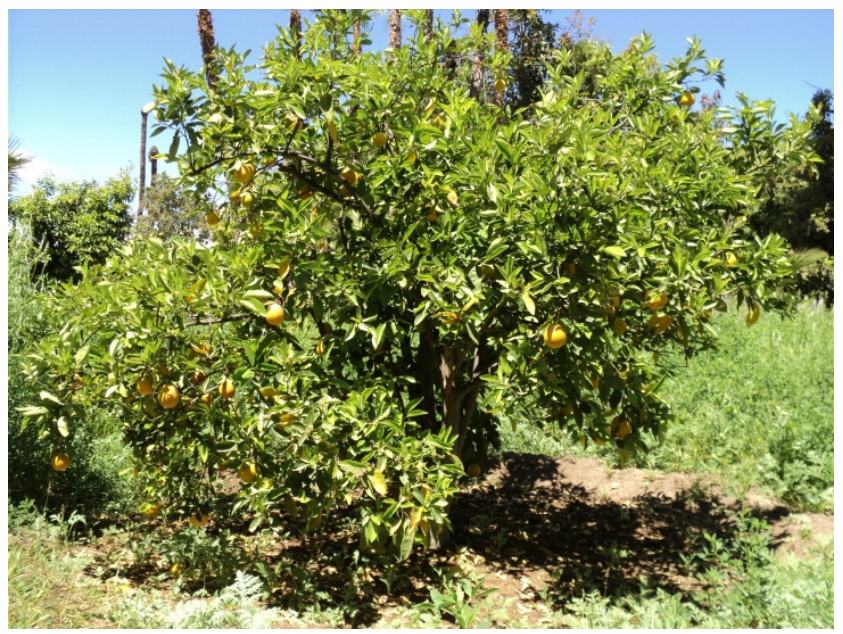

$\mathrm{C}+\mathrm{VEF} 4$ 


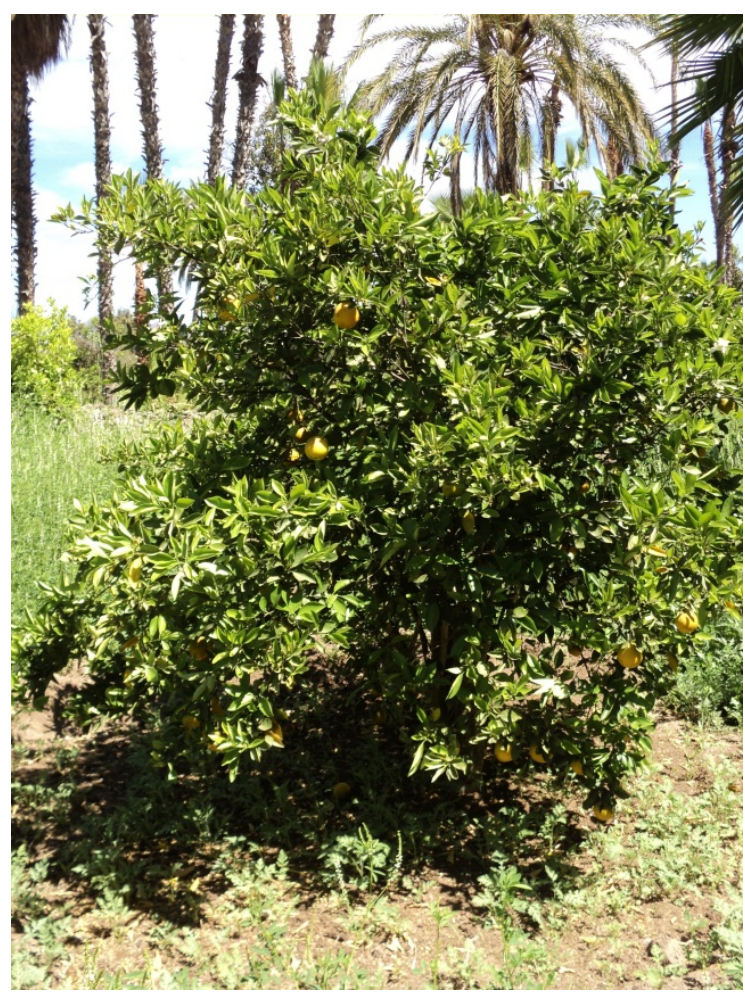

$\mathrm{C}+$ VEF 5

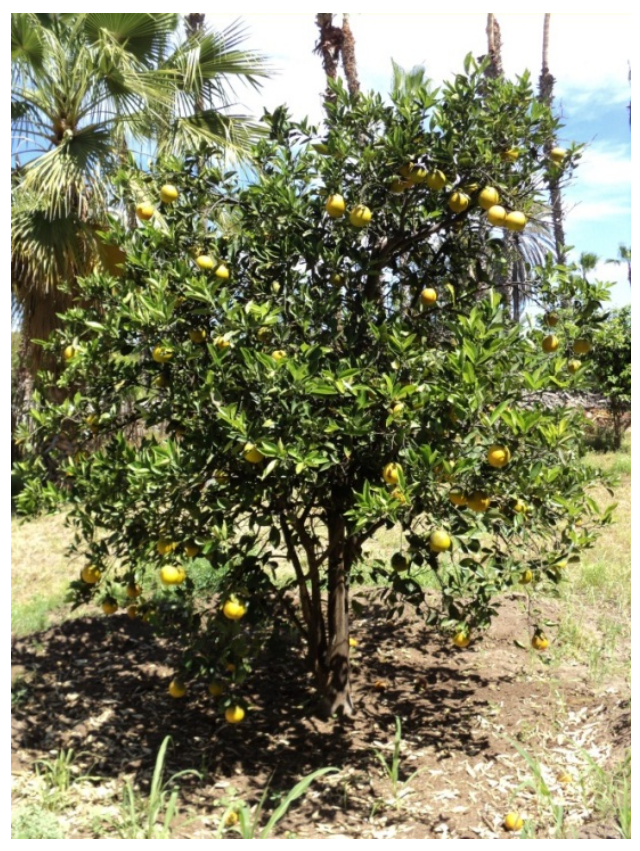

C+VEF 7

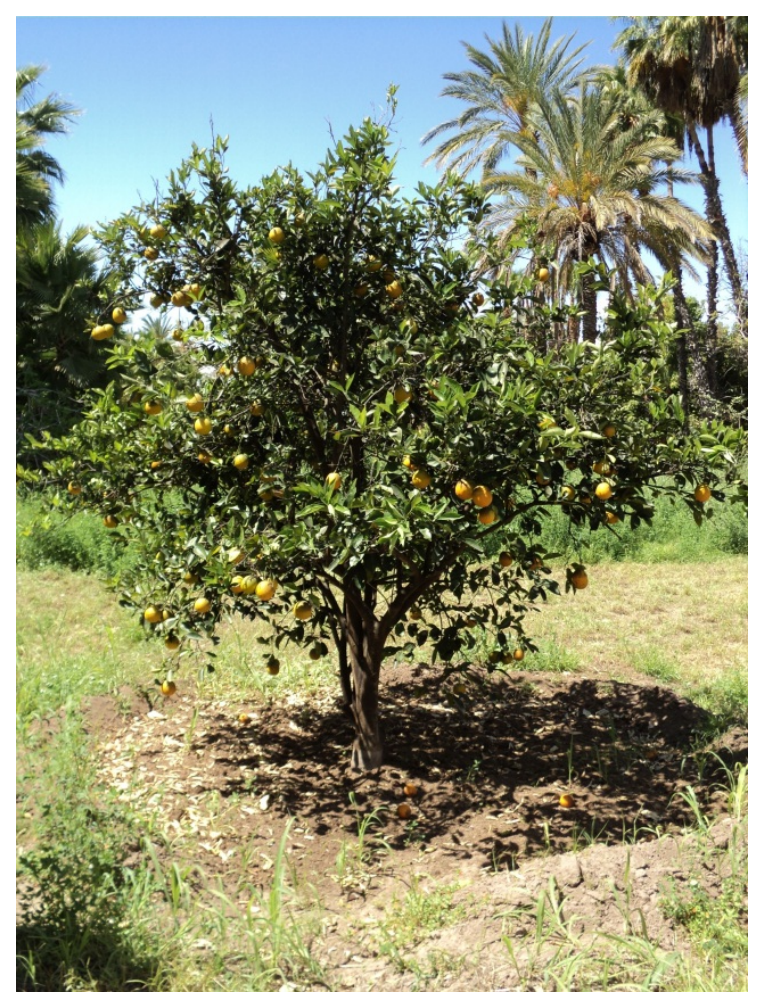

C+VEF 6

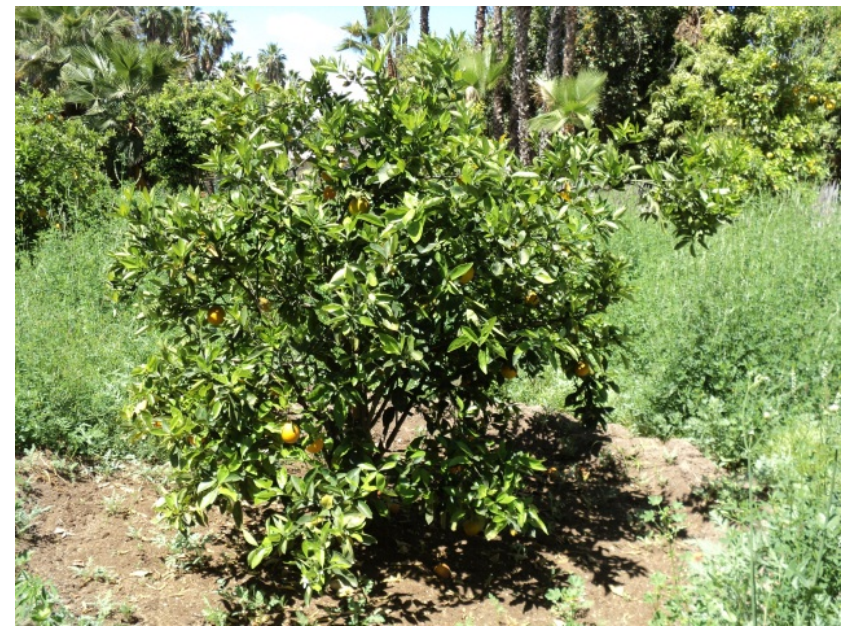

C+VEF 8 


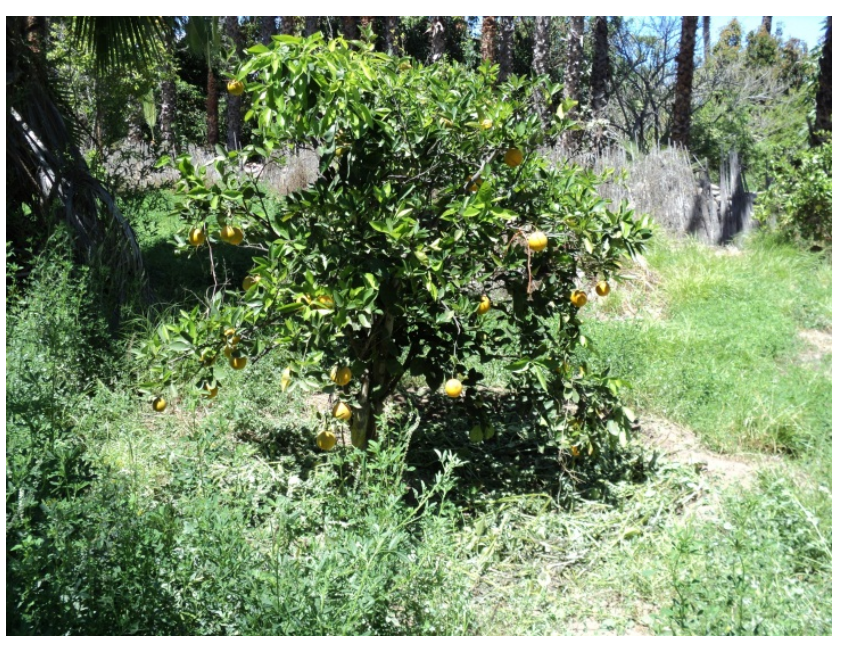

$\mathrm{LCC}+\mathrm{VEF} 1$

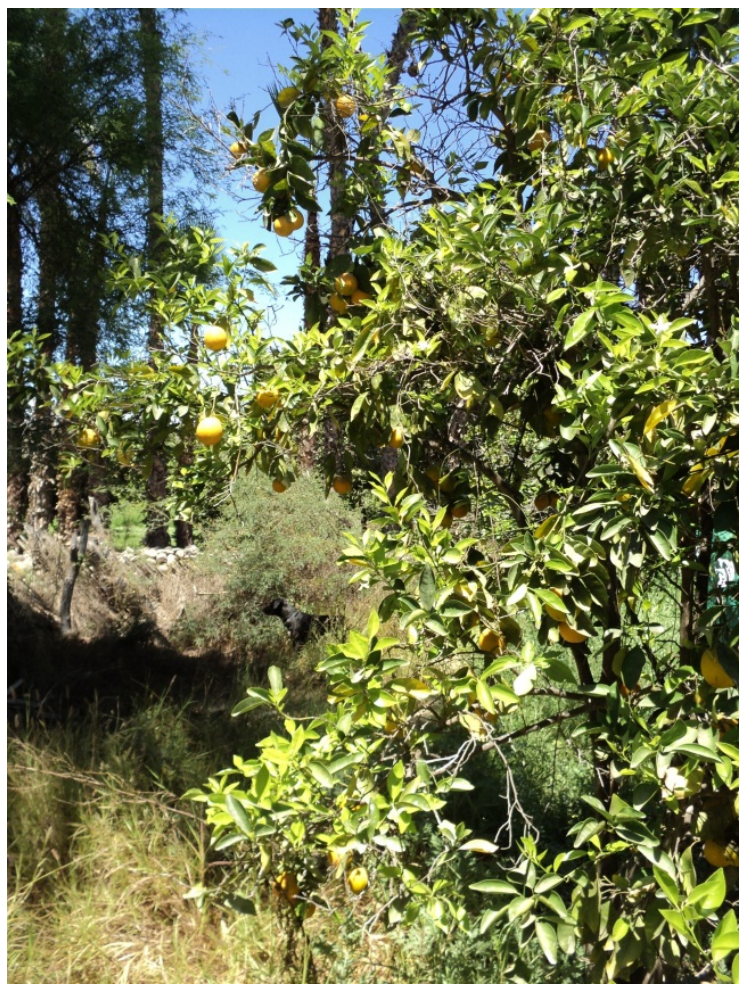

$\mathrm{LCC}+\mathrm{VEF} 3$

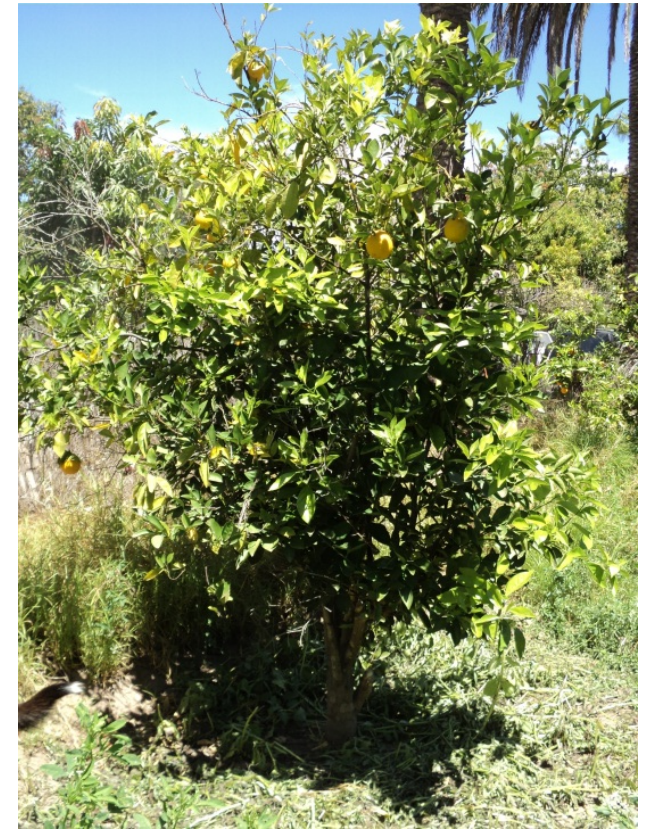

$\mathrm{LCC}+\mathrm{VEF} 2$

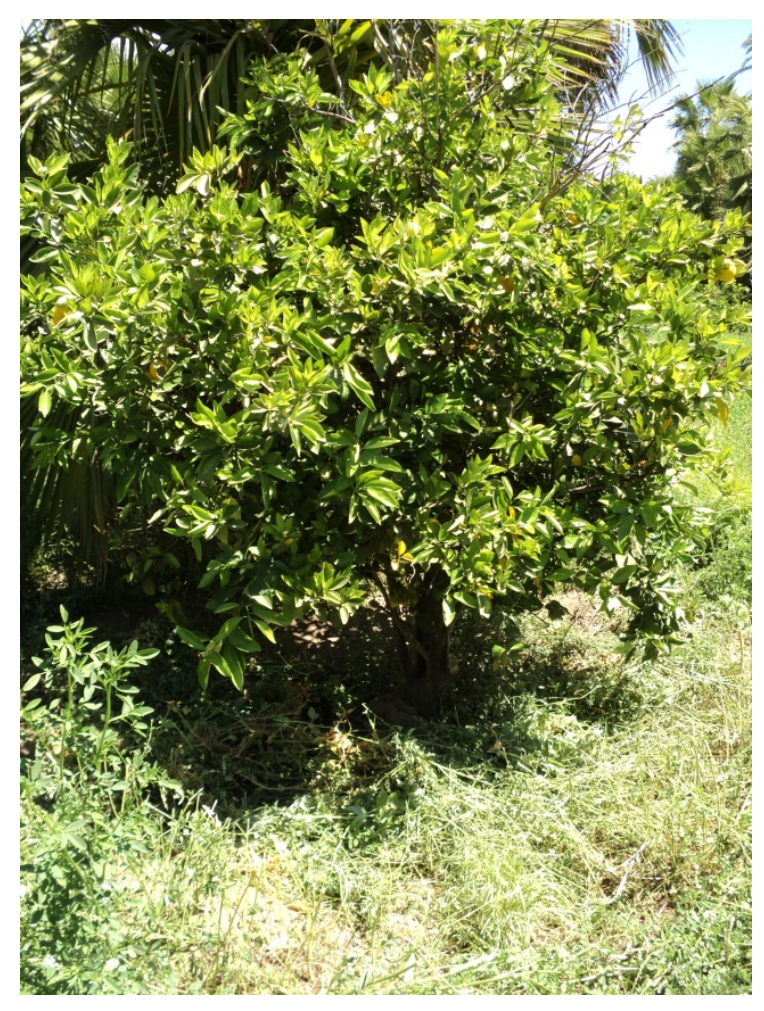

$\mathrm{LCC}+\mathrm{VEF} 4$ 


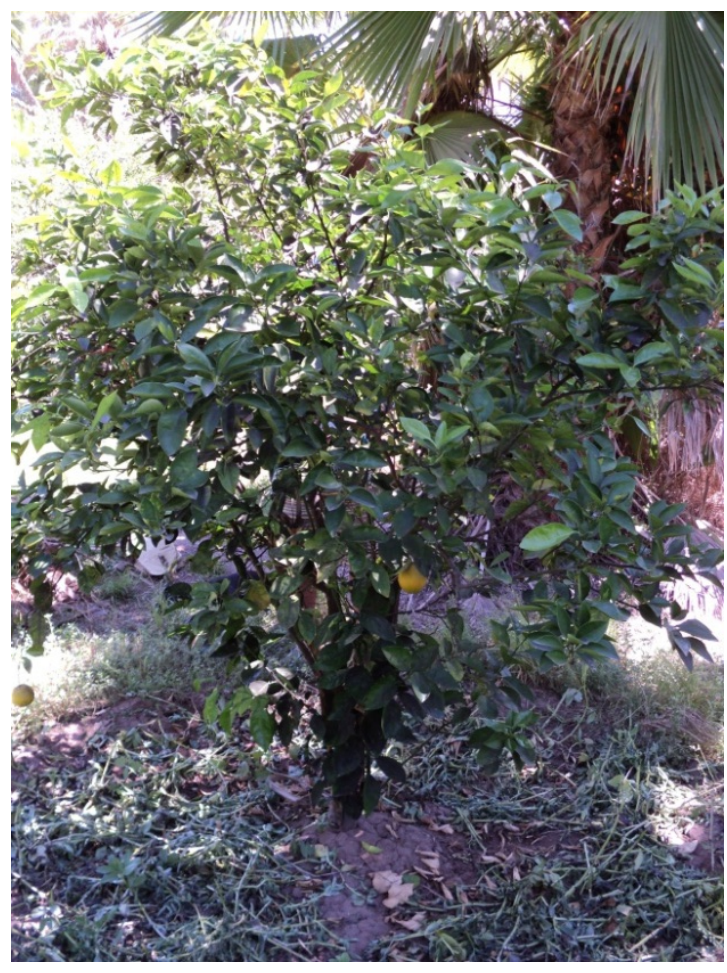

LCC+VEF 5

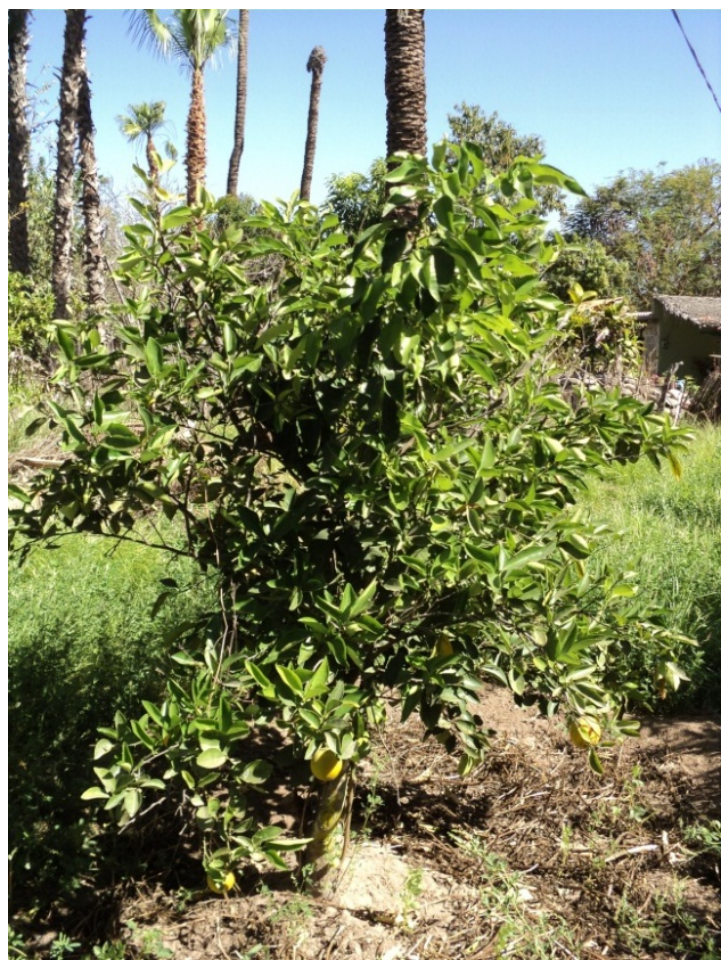

LCC+VEF 7

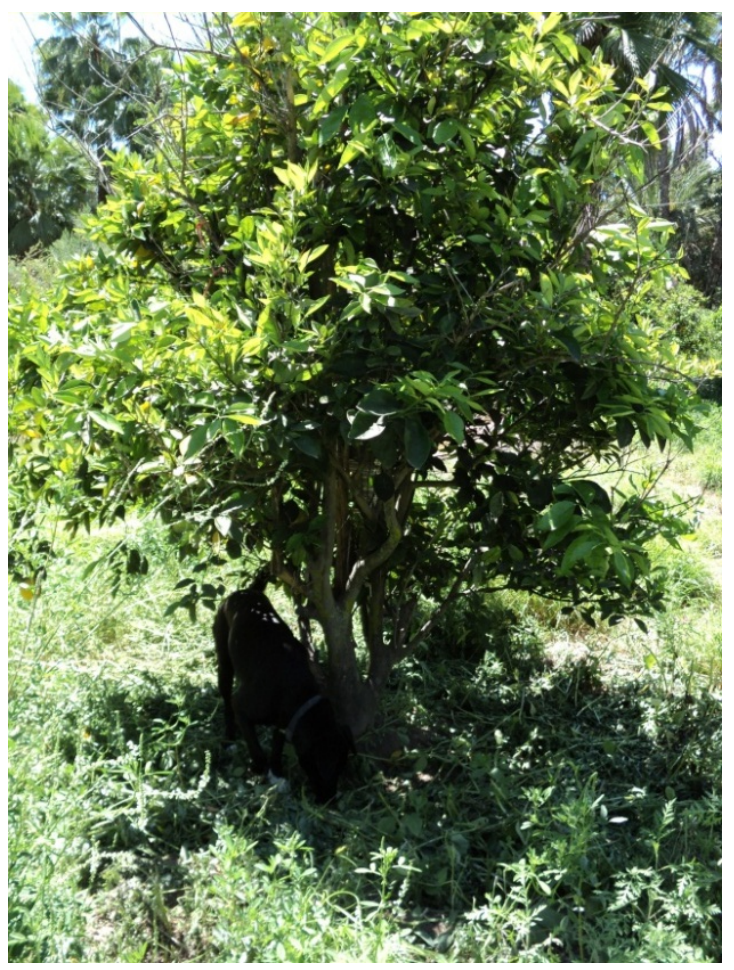

LCC+VEF 6

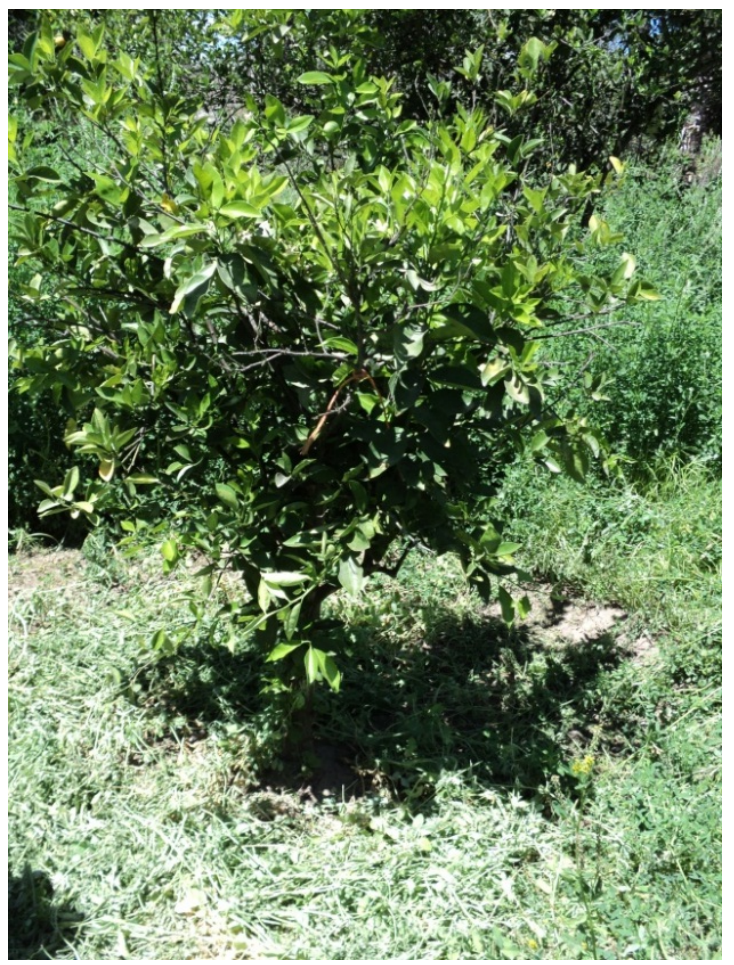

LCC+VEF 8 


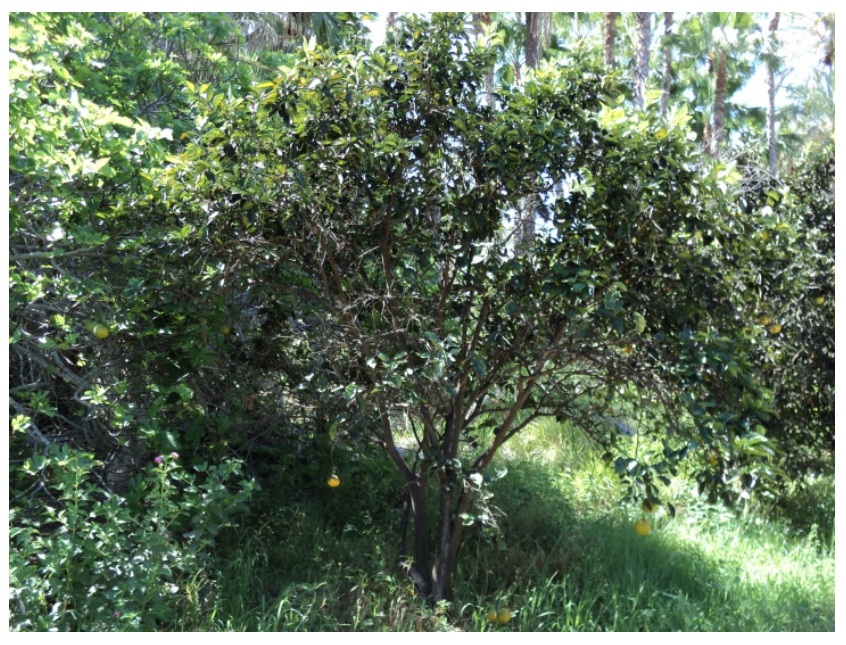

VEF 1

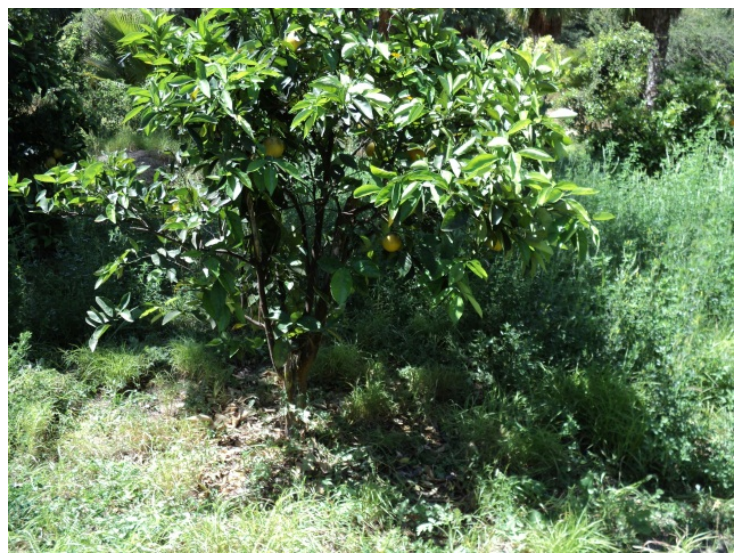

VEF 3

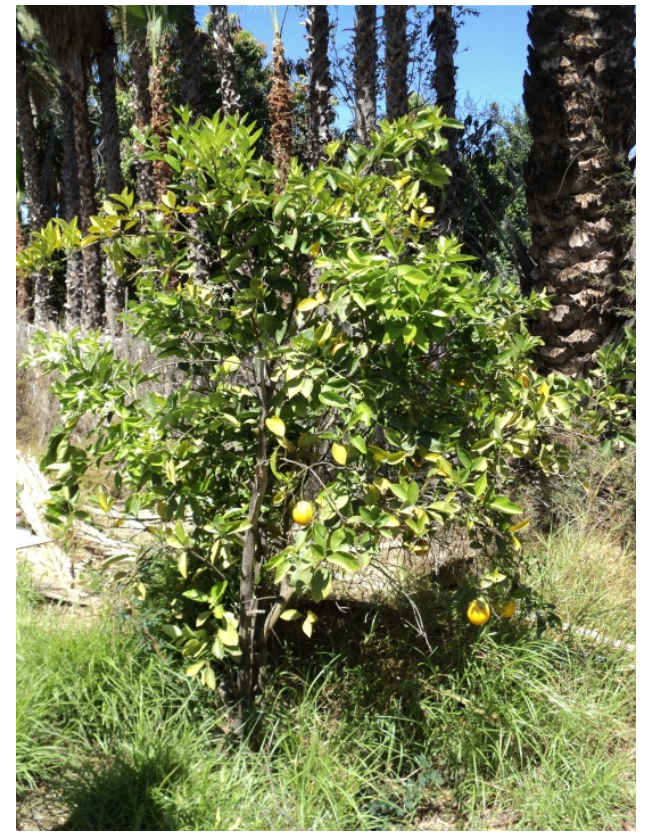

VEF 2

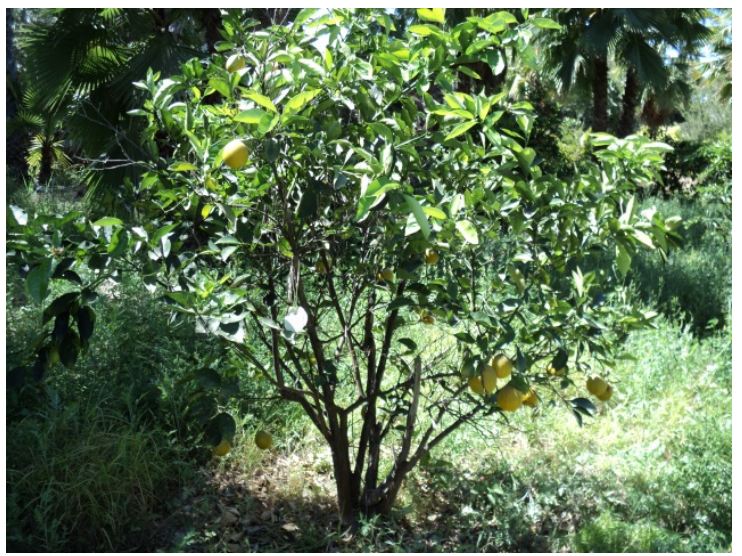

VEF 4 


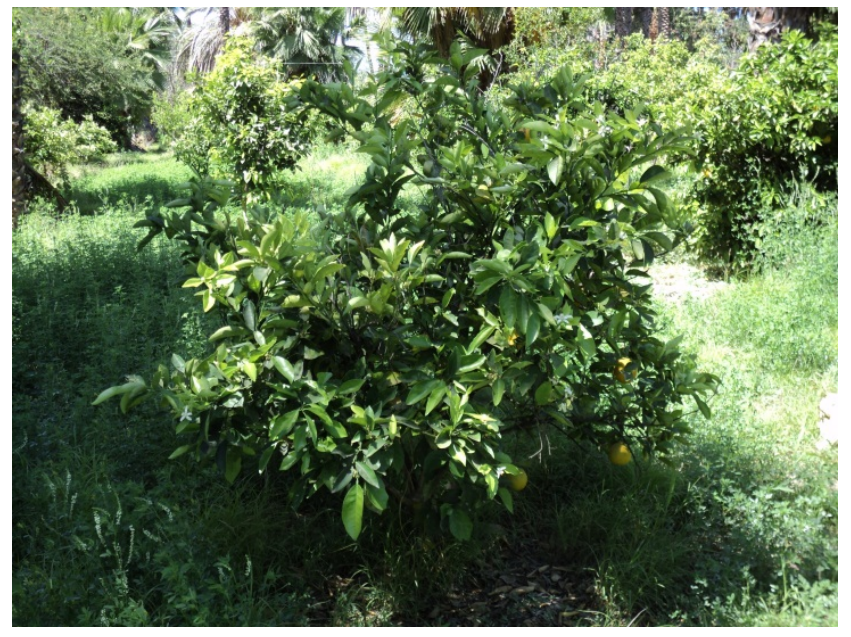

VEF 5

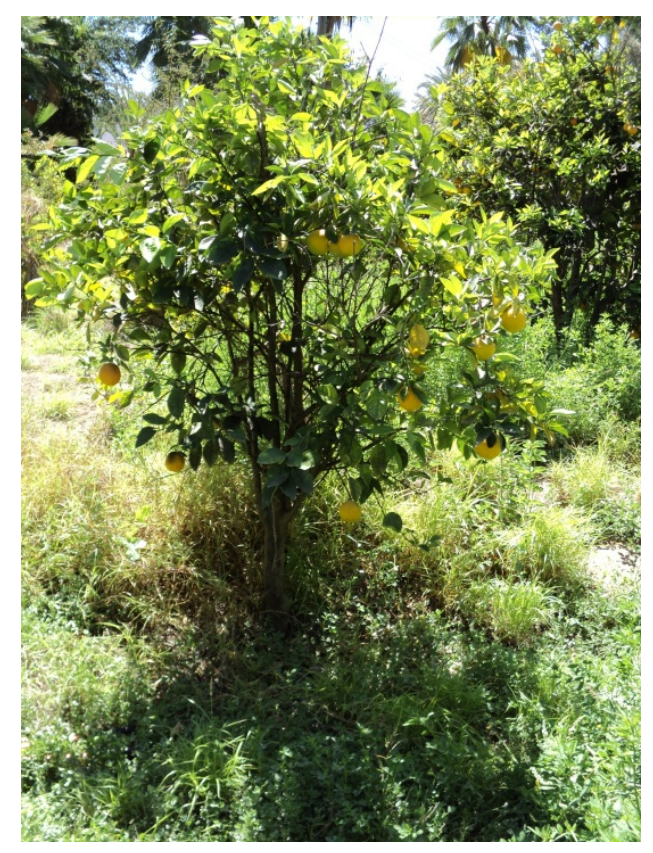

VEF 6

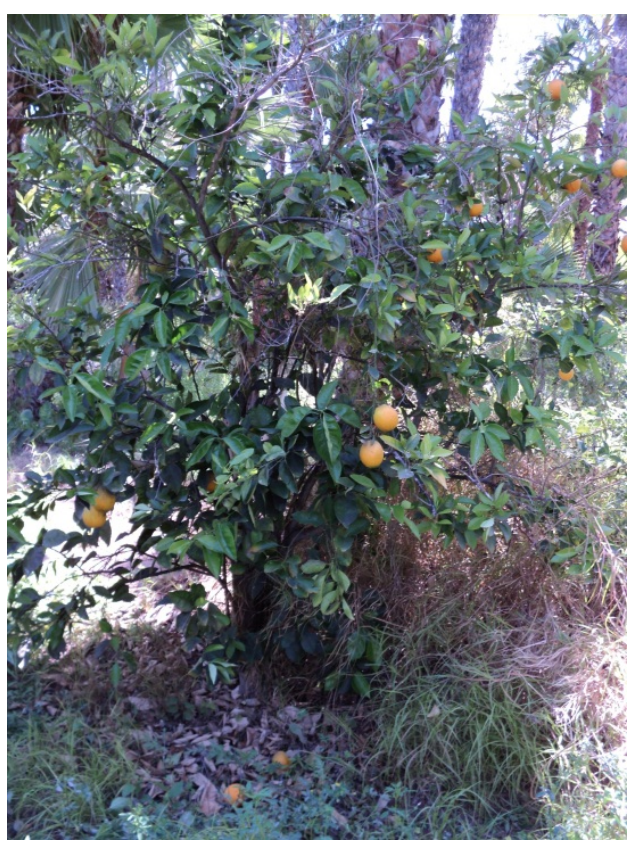

VEF 7

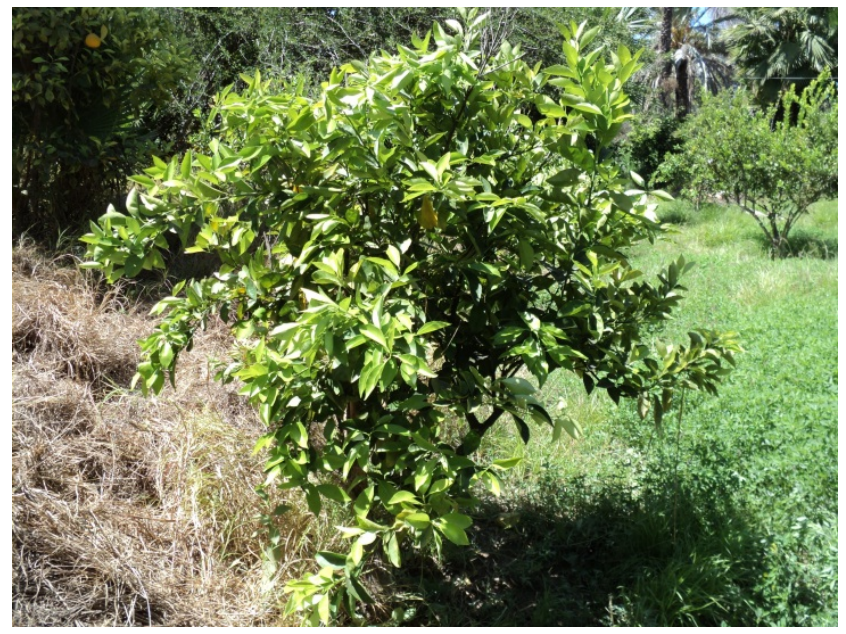

VEF 8 


\section{Control}

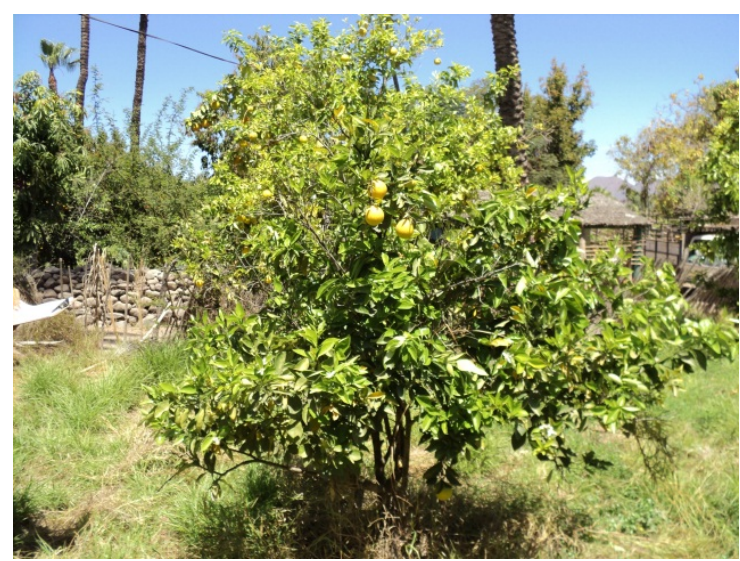

Control 1

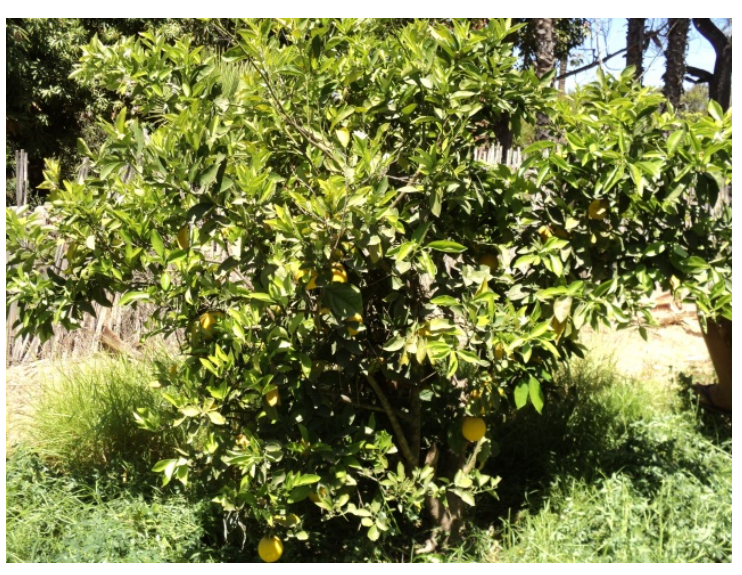

Control 2

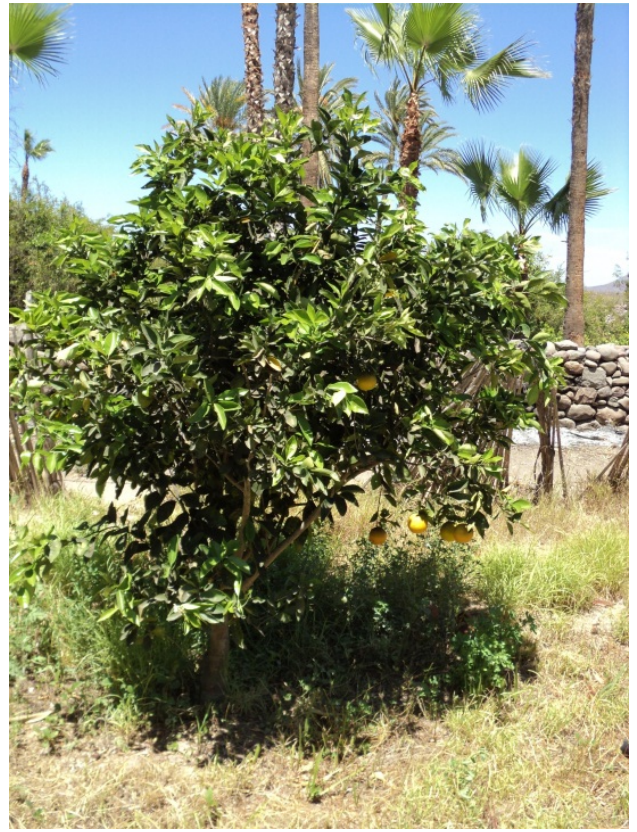

Control 3

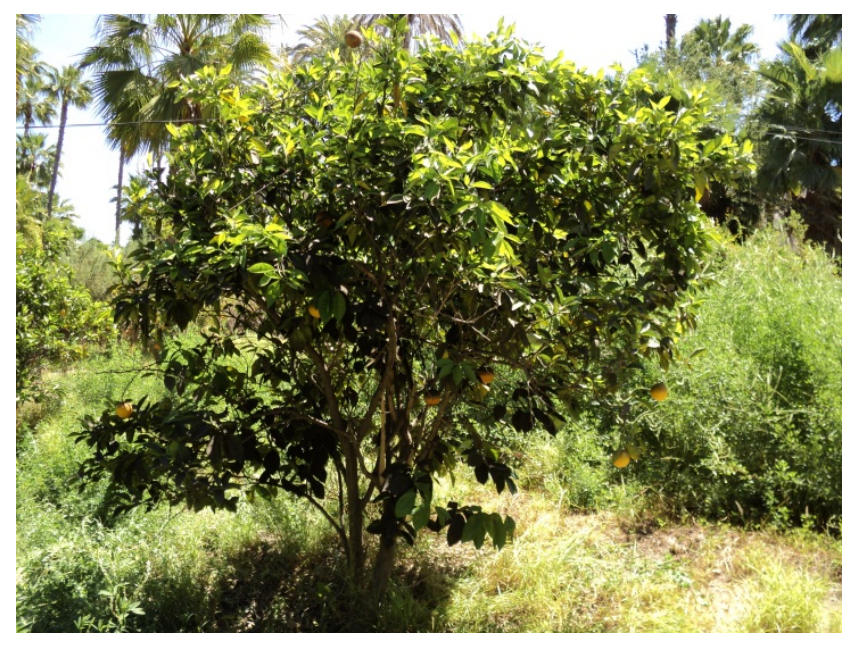

Control 4 


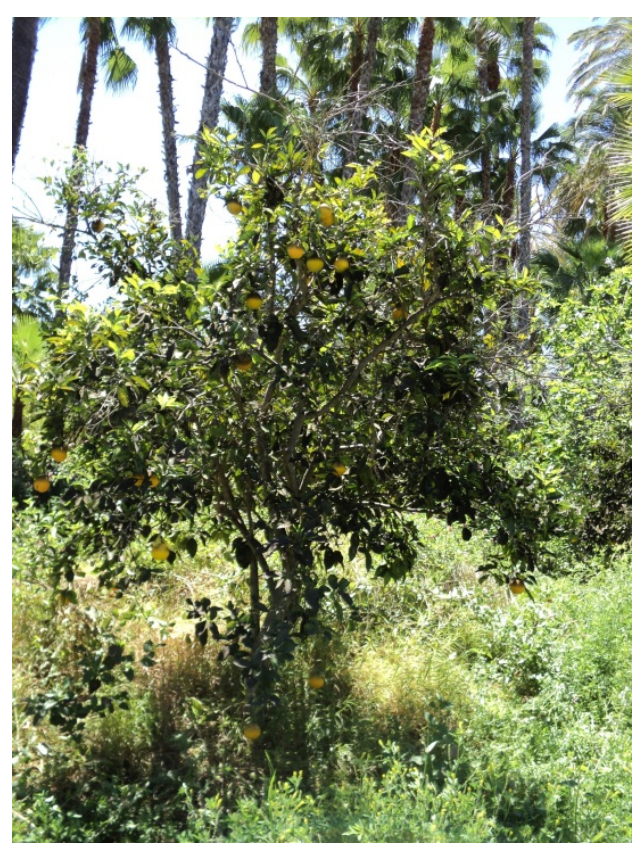

Control 5

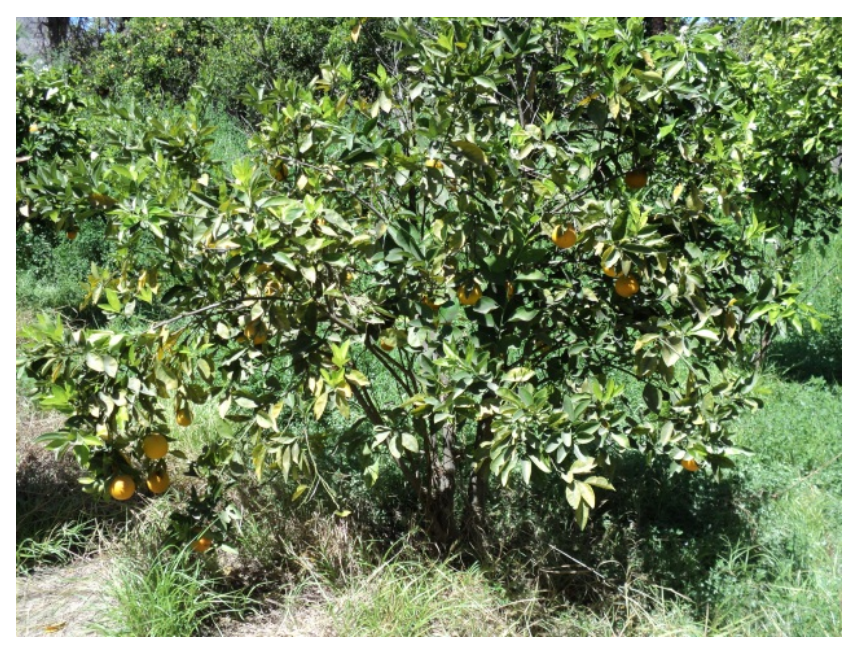

Control 7

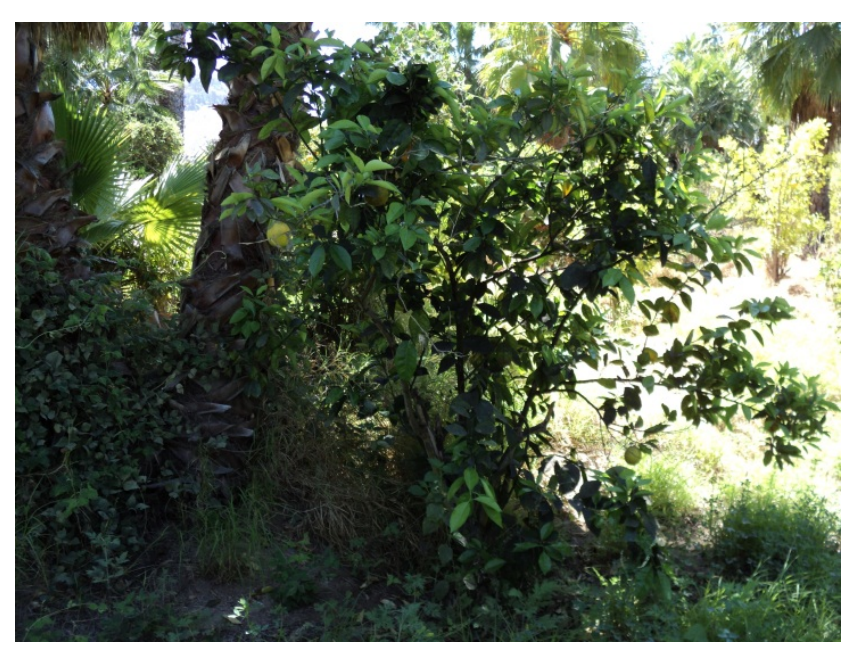

Control 6

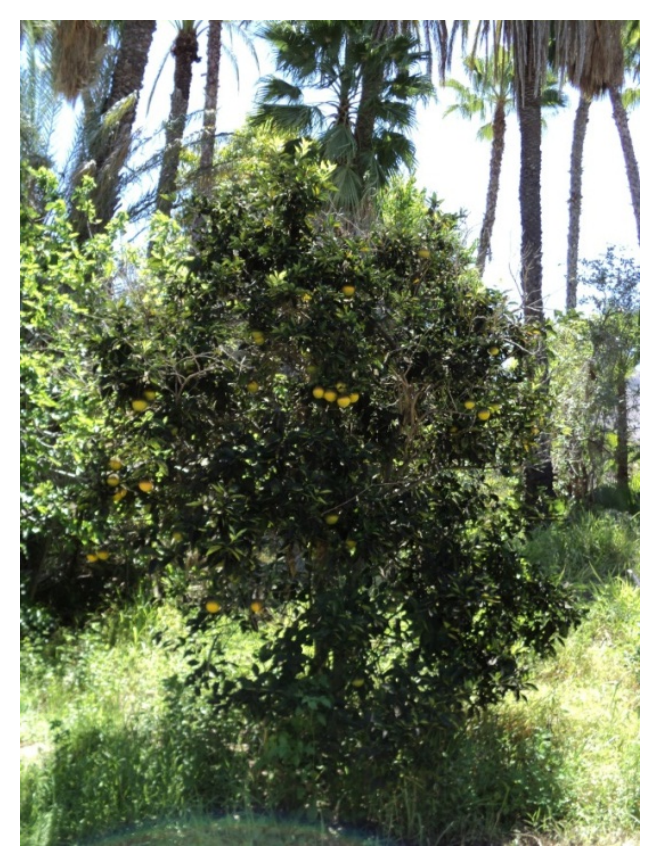

Control 8 
Google Earth Photo of Experimental WNO Orchard

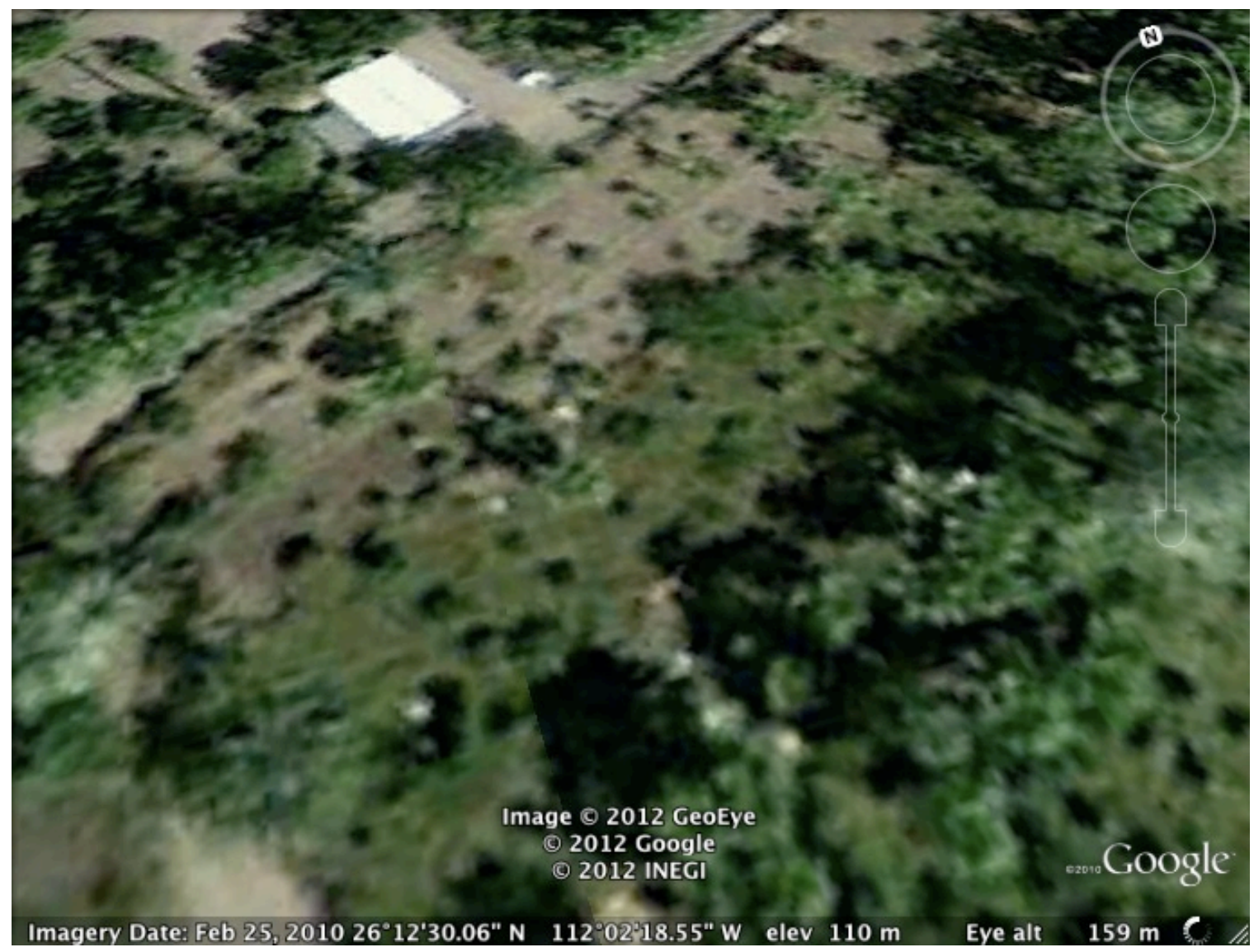

All Treatments of the Experiment were Implemented on WNO Trees within this Orchard Randomly 